\title{
9. GEOLOGIC EVOLUTION, SEDIMENTATION, AND PALEOENVIRONMENTS OF THE ANGOLA BASIN AND ADJACENT WALVIS RIDGE: SYNTHESIS OF RESULTS OF DEEP SEA DRILLING PROJECT LEG $7^{1}$
}

\author{
Walter E. Dean, U. S. Geological Survey, Denver, Colorado \\ William W. Hay, University of Colorado, Boulder, Colorado \\ and \\ Jean-Claude Sibuet, Centre Océanologique de Bretagne, B.P. 337, 29273 \\ Brest Cedex, France
}

\begin{abstract}
The section recovered at Site 530 (Holes 530A and 530B) consists of eight sedimentary units and one basalt unit. The composition of the basalt recovered in Hole 530A is distinct from typical mid-ocean ridge basalts (MORBs) but is similar to that of Hawaiian tholeiites and basalt from the central part of Walvis Ridge. Throughout most of its history, the southern Angola Basin received large volumes of redeposited material in the form of turbidites and, most recently, debris-flow deposits. Most of this material was derived from Walvis Ridge to the south, but thickness trends of acoustic units suggest that some of the sediment was derived from the African continental margin to the east.

The basal sedimentary unit (Albian to Santonian) at Site 530 contains 262 beds of black shale that are interbedded with green and red claystone. Black shale makes up less than $10 \%$ of the total section, but in two cores of early Turonian age, black shale beds compose about $50 \%$ of the section. The black shales contain up to $19 \%$ organic carbon (average of about $5 \%$ ) that is mainly of autochthonous marine origin but with significant contributions from terrigenous organic matter. The origin of these more- and less-reduced interbedded lithologies with varying amounts and types of organic matter, and variable amounts of pelagic, hemipelagic, and turbiditic sediment is complex and cannot be explained by any one simple process. Many factors affecting the concentration of dissolved oxygen in the bottom waters of the Angola Basin varied throughout the middle Cretaceous to produce bottom-water conditions that fluctuated between mildly oxic and oxygen-deficient, but most of the time bottom-waters and sediment-interstitial waters were sufficiently oxic to permit the accumulation of red oxidized sediment.

A relatively complete sedimentary record of the Cretaceous/Tertiary boundary was recovered within a sequence of mudstone and marlstone turbidites in Hole 530A. There is a significant increase in the concentration of iridium above background levels at the boundary. High concentrations of many other elements also occur within the same stratigraphic interval as the iridium anomaly. Furthermore, there is a marked decrease in $\mathrm{CaCO}_{3}$ in the Tertiary strata above the iridium anomaly which suggests that the production of shallow-water carbonate also may have been affected by whatever caused elevated concentrations of iridium and other elements. These observations are consistent with the asteroid-impact theory proposed to explain the worldwide occurrence of an iridium anomaly at the Cretaceous/Tertiary boundary.

The Cenozoic history of the Angola Basin was controlled mainly by (1) restriction of bottom-water flow from the south by Walvis Ridge; (2) development of glaciation on Antarctica; (3) opening of circulation passages in the southern oceans; (4) rapid turnover of cold, nutrient-rich waters that resulted in high productivity of diatoms; (5) influx of terrigenous sediment mainly by turbidity currents; and (6) production and preservation of carbonate sediment. The most distinctive Cenozoic event recorded in the section at Site 530 is the beginning of extensive glaciation on Anarctica and concomitant initiation of modern thermohaline bottom-water circulation that is manifested as a middle Eocene to middle Oligocene unconformity or compressed section accompanied by a drastic decrease in accumulation of $\mathrm{CaCO}_{3}$. Diatom abundances in HPC cores from Walvis Ridge (Site 532) and Angola Basin (Hole 530B) indicate that Benguela upwelling in these areas began in the late Miocene, reached a peak in the late Pliocene to early Pleistocene, and declined thereafter. Short-term variations in sediment composition at Site 532 are manifested as cyclic variations in concentrations of clay, $\mathrm{CaCO}_{3}$, and organic carbon with average periodicities of about 30-60 k.y. The main variability that produced the cycles probably was the influx of terrigenous clastic material which diluted the $\mathrm{CaCO}_{3}$. The sediment at Site 532 also contains several percent organic carbon that is dominantly of marine origin, but with significant terrigenous components.

Data from multichannel seismic, gravity, and magnetic surveys were used to define the regional stratigraphic and structural evolution of Walvis Ridge and adjacent Cape and Angola basins. Six structural provinces are recognized, four on Walvis Ridge and two additional provinces that correspond to the Cape and Angola basins. The two eastern structural provinces on Walvis Ridge are underlain by continental crust. The two western structural provinces are underlain by oceanic basement. Two main directions of faults are evident in seismic profiles, one trending $\mathrm{N} 10^{\circ}$ and one trending $\mathrm{N} 60^{\circ}$. The $\mathrm{N} 60^{\circ}$ trend corresponds to the general orientation of the northern and southern flanks of Walvis Ridge as well as to the dominant direction of fracture zones.

During the first phase of separation of Africa from South America (ca. 120-130 m.y. ago), a voluminous mass of volcanics was emplaced simultaneous with the emplacement of basalt in the Parana Basin of Brazil and the Kaokoveld Region of South Africa. This period of volcanism also formed the series of seaward-dipping internal basement reflectors that are characteristic of the two structural provinces of Walvis Ridge. A system of fault blocks developed in the brittle upper part of the newly formed crust. During the second phase of rifting, which ended before late Aptian, more tilted fault blocks were created in the upper brittle stratified continental crust. Magnetic lineations in basement rocks in the Angola and Cape basins in the vicinity of Walvis Ridge are not distinct but suggest that oceanic crust began to be emplaced between 120 and 112 m.y. ago (Barremian to early Aptian). At least part of the oceanic crust of the central plateau of eastern Walvis Ridge (structural province 3) may have been emplaced before any oceanic crust formed in the adjacent basins. A ridge jump occurred during the late Aptian to early Albian in the southern part of the Angola Basin which translated the previously formed oceanic crust and its overlying evaporite deposits on the South American side. Several ridge jumps occurred on both sides of Walvis Ridge during the Late Cretaceous and early Tertiary to produce a 500-km-long segment of mid-ocean ridge.
\end{abstract}

${ }^{1}$ Hay, William W., and Sibuet, Jean-Claude, et al., Init. Repts. DSDP, 75: Washington (U.S. Govt. Printing Office). 


\section{INTRODUCTION}

The main objective of drilling on Leg 75 was to study late Mesozoic and Cenozoic paleoenvironments in the southern Angola Basin and on the adjacent Walvis Ridge. In particular we wanted to detail the development of Cretaceous organic-carbon-rich facies that are widespread in both the North and South Atlantic, to evaluate the effect of the Walvis Ridge as a barrier to deep oceanic circulation in the South Atlantic, and to obtain a detailed record of the development of the Benguela upwelling system during the Neogene.

Sediments rich in organic carbon $(>2 \%)$ are rare in the modern open ocean. The location and extent of depositional environments that result in accumulation of organic matter are of great interest, however, because they serve as models for understanding the origin and diagenesis of source rocks for hydrocarbons in ancient strata. Today, organic-carbon-rich sediments are restricted either to isolated basins in which the bottom waters are stagnant or renewed very slowly, or to areas of the seafloor that intersect midwater oxygen minimum zones which develop under highly fertile surface-water masses along continental margins where there is upwelling of nutrient-rich deeper waters. Examples of the first type of environment, restricted basin, are the Black Sea, the Cariaco Trench off Venezuela, the Orca Basin off Texas, and the Guaymas Basin in the Gulf of California. Examples of organic-carbon-rich sediments that have accumulated under an oxygen minimum zone are found off the coasts of Peru and Ecuador, southwest and northwest Africa, southwest India, and western Mexico.

Conditions favorable for the development of organiccarbon-rich strata in the deep sea occurred several times during the Cretaceous. In the South Atlantic, seven DSDP sites in addition to Site 530 recovered organiccarbon-rich mid-Cretaceous strata (see reviews by Dean, Arthur, and Stow; Stow and Dean; and Gilbert, all this volume). To the south, Sites 327,330 , and 511 on the Falkland Plateau recovered mostly open-marine, oxygenated sediments, but older Cretaceous to Jurassic organic-carbon-rich strata of variable lithology also were recovered at Sites 330 and 511 (Barker, Dalziel, et al., 1976; von der Dick et al., 1983; Ludwig, Krasheninnikov, et al., 1983). Organic-carbon concentrations average about $4 \%$ in the Hauterivian to lower Aptian strata at Site 511 in the Argentine Basin, and are less than 1\% in the Aptian to Albian strata (von der Dick et al., 1983; Gilbert, this volume). Site 361 in the Cape Basin recovered Aptian dark gray shales with organic carbon contents that vary from $0.4 \%$ to $21.7 \%$ (Natland, 1978; Gilbert, this volume). Sites 356 and 357 on the São Paulo Plateau and Rio Grande Rise comprise interbedded marlstone, chalk, limestone, and black shale containing mostly less than $1 \%$ organic carbon. Site 363 on Walvis Ridge showed fine, thin black-shale horizons within a sequence of marlstone and mudstone. These shale horizons contain less than $1 \%$ organic carbon as poorly preserved terrestrial and coaly organic matter. Two distinct organic-carbon-rich intervals were penetrated at Site 364 on the eastern slope of the Angola Ba- sin (Bolli, Ryan, et al., 1978). The oldest interval is Aptian-Albian dolomitic marlstone that contains an average of about $10 \%$ organic carbon mainly of marine origin (Tissot et al., 1980; Gilbert, this volume). The upper interval at Site 364 is late Albian to Santonian in age and is equivalent to the organic-carbon-rich interval cored at Site 530. This younger interval consists of cyclic interbeds of black shale and green calcareous mudstone and chalk. The black shales contain up to $23 \%$ organic carbon mainly of marine origin.

Evidence from DSDP Site 362 on Walvis Ridge suggested that accumulation of siliceous biogenic sediment in response to the development of the Benguela upwelling system off southwest Africa began in the late Miocene (about 10 m.y. ago; Diester-Haass and Schrader, 1979; Siesser, 1980). Drilling at Site 362 was done with older rotary drilling methods that highly disturb unconsolidated sediment. The recently developed hydraulic piston core (HPC) provided the opportunity to collect a complete undisturbed record of the development of this important upwelling system.

Unlike the Rio Grande Rise, the Walvis Ridge has no deep passages to permit northward flow of bottom waters, and may have served as a barrier to circulation and as a dam to the transport of sediment by bottom currents. The eastern segment of Walvis Ridge is everywhere shallower than $2000 \mathrm{~m}$. The middle segment is separated from the eastern segment by a depression that is more than $3000 \mathrm{~m}$ deep but is otherwise less than 2000 $\mathrm{m}$ deep. The western segment is lower and has the deepest passage (Walvis Passage) with a sill depth between 3500 and $4000 \mathrm{~m}$. The Walvis Ridge is thought to act as a barrier to the flow of Antarctic Bottom Water (AABW) into the Angola Basin. As a consequence, any $\mathrm{AABW}$ in the Angola Basin probably enters through the Romanche Fracture Zone at the northern end of the Angola Basin. Neuman and Pierson (1966) estimated that the bottom water of the Angola Basin contains only several percent AABW. As a result, the bottom water of the Angola Basin has a potential temperature of $+2.0^{\circ} \mathrm{C}$ compared with a potential temperature of $-0.45^{\circ} \mathrm{C}$ for AABW at its source off Antarctica. Connary and Ewing (1974) concluded, however, that AABW has entered the Angola Basin through the Walvis Passage since the late Miocene.

Another primary objective of Leg 75 was to understand the mode of formation and early evolution of the Walvis Ridge and of the adjacent continental margins and oceanic basins. The major questions which had been raised by previous geological and geophysical surveys concerned the age of the southern part of the Angola Basin and the problem of whether the eastern part of Walvis Ridge had a continental or oceanic origin. Most aseismic ridges have been created or modified by relocations or jumps of spreading centers as has been documented for Hess and Shatsky Rises (Vallier et al., 1981 and 1983), Walvis Ridge (Moore, Rabinowitz et al., in press), and the Rio Grande Rise (Supko, PerchNielsen, et al., 1977). Cande and Rabinowitz (1978) suggested that a spreading ridge jump occurred in the southern Angola Basin at approximately the time of 
magnetic anomaly M0 (Aptian), although the identification of magnetic lineations was very difficult. One specific objective of Leg 75 was to test the jump hypothesis by dating basement at a critical location in the Angola Basin. The eastern part of Walvis Ridge was generally assumed to be of oceanic origin (Dietz and Holden, 1970; Morgan, 1971 and 1972; Francheteau and LePichon, 1972; Goslin and Sibuet, 1975), but the contact between the crust of oceanic origin and the continental crust had never been determined. Van der Linden (1980) had suggested that much of the ridge might be underlain by a sliver of continental crust.

When the area of the southern Angola Basin and adjacent Walvis Ridge was first selected as a potential target of interest for IPOD drilling, published information was scarce (Goslin et al., 1974; Barnaby, 1974; Goslin and Sibuet, 1975; Emery et al., 1975) and only single channel seismic data were available. Three institutions, the Centre Oceanographique de Bretagne (COB), Institut Français de Pétrole (IFP), and Bundesanstat für Geowissenschaften and Rohstoffe (BGR), that were interested in the program then carried out two multichannel regional surveys in $1977(5,000 \mathrm{~km}$ of line with the R/V Résolution) and 1978 (5,000 km of line with the R/ V Explora). The University of Texas conducted the final multichannel site survey in 1979 (Musgrove and Austin, 1983 and this volume). Multichannel seismic surveys of Walvis Ridge displayed dipping reflectors within the acoustic basement (Hinz, 1981). An additional objective, then, was to determine whether this basement with internal dipping reflectors is sedimentary or volcanic.

The locations of the drill sites are shown on the new bathymetric map prepared by Sibuet et al. (this volume) which shows Walvis Ridge and adjacent parts of the Angola and Cape Basins (Fig. 1). The eastern (Frio) segment of Walvis Ridge is a linear feature that trends $\mathrm{N}$ $60^{\circ}$. It has a relatively constant width of $130 \mathrm{~km}$, and it has a mean depth of $2,500 \mathrm{~m}$. To the south of the ridge, the Cape Basin is $4,000 \mathrm{~m}$ deep, and to the north the Angola Basin is $5,000 \mathrm{~m}$ deep. The southern flank of Walvis Ridge is distinguishable only to the west of $9^{\circ} \mathrm{E}$, but it can be traced east to $11^{\circ} \mathrm{E}$ on the map of acoustic basement.

\section{SITE 530}

Site 530 is located in the southeastern corner of the Angola Basin, about $20 \mathrm{~km}$ north of the northern escarpment of Walvis Ridge (Fig. 1). The site is on the abyssal floor of the Angola Basin and is underlain by a seismic stratigraphic sequence that is typical of the entire deep part of the basin (Sibuet et al., this volume). The main objective of drilling at Site 530 was to investigate the paleoceanographic evolution of the Angola Basin, particularly with regard to the conditions of deposition of Cretaceous black shales which are widespread in both the North and South Atlantic, but whose origin is

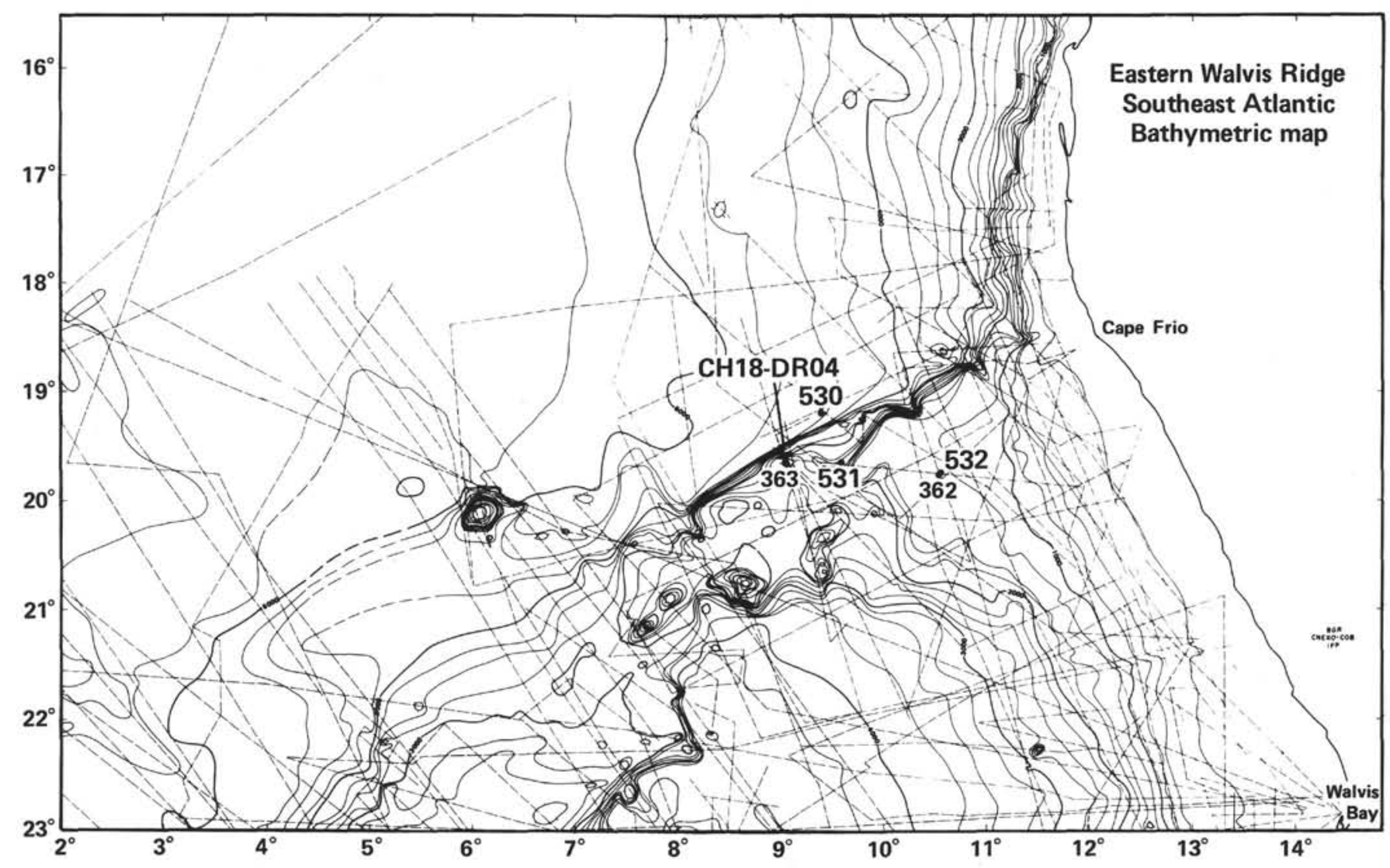

Figure 1. Bathymetric map of the eastern Walvis Ridge and adjacent parts of the Cape and Angola basins on a Mercator projection. Tracklines for seismic reflection data used as control are shown as dashed lines. Depths are in corrected $\mathrm{m}$. Contour interval is $250 \mathrm{~m}$. Locations of dredge $\mathrm{CH}$ 18-DR06 and DSDP drill sites also are shown. 

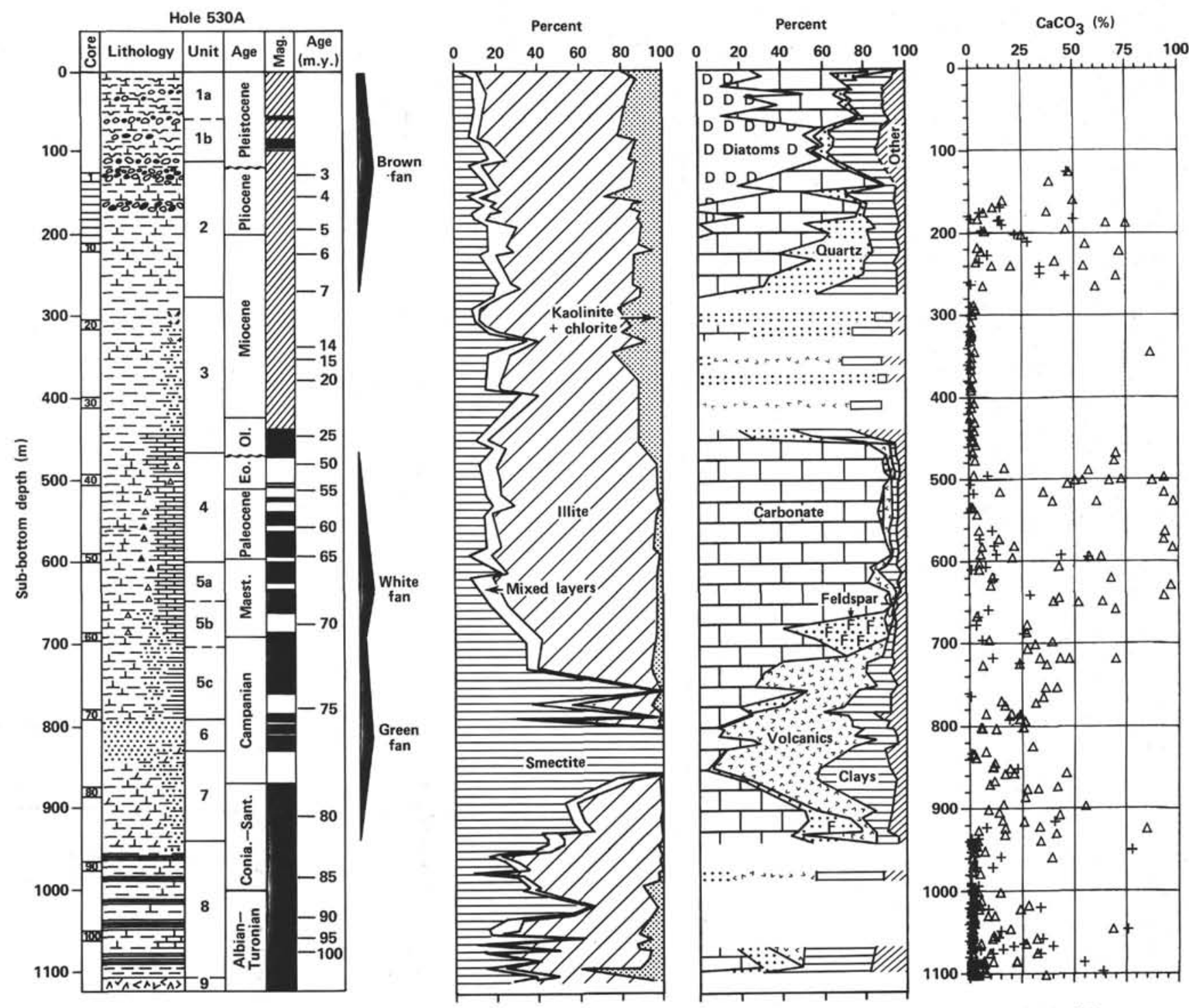

$\triangle$ Dean and Parduhn

+ Meyers, Brassell, and Huc

Figure 2. Hole summary chart, Hole 530A, southern Angola Basin. The data for the summary are compiled from the following sources: Deepsea fan facies, clay mineralogy, and major sediment components from Stow (this volume); percent $\mathrm{CaCO}_{3}$ from Dean and Parduhn, and Meyers, Brassell, and Huc (this volume); drilling rate from Site 530 chapter (this volume); percent organic carbon $\left(\mathrm{C}_{\mathrm{org}}\right)$ from Meyers, Brassell, and Huc (this volume); Rock-Eval S-2 from Site 530 chapter (this volume); relative change in sea level, Vail et al. (1977). Mass accumulation rates (MARs) of bulk sediment, nonbiogenic components, $\mathrm{CaCO}_{3}$, and organic carbon were computed from data in Meyers, Brassell, and Huc, Dean and Parduhn, Steinmetz and Stradner, Stradner and Steinmetz, and Site 530 chapter (all this volume); sedimentation rate from Steinmetz and Stradner, and Stradner and Steinmetz (this volume); abundance and preservation of foraminifers and nannofossils, gamma rays, neutrons, wet-bulk density, porosity, water content, compressional sound velocity, and acoustic impedance from Site 530 chapter (this volume).

still a matter of debate. The subsidence history at Site 530 should complement information gained on Legs 73 and 74, and should permit definition of lithofacies and/ or paleoenvironments across the northern flank of Walvis Ridge and of the history of the carbonate compensation depth (CCD) in the Angola Basin. Another objective of drilling at Site 530 was to determine the age of basement in this part of the Angola Basin and hopefully to help discriminate between alternative views of the early spreading history of this area, and in particular to establish whether the hypothesis of a ridge jump in the southern
Angola Basin is correct (Cande and Rabinowitz, 1978; Sibuet et al., this volume).

Three holes were drilled at Site 530. After two cores were recovered from Hole 530, a heat flow tool became jammed in the bit and the hole had to be abandoned. Hole $530 \mathrm{~A}$ penetrated $1121 \mathrm{~m}$ of section including $19 \mathrm{~m}$ of basalt at the bottom of the hole. This hole was abandoned when the bit wore out. The average recovery of sediment from Hole $530 \mathrm{~A}$ was $62 \%$. The upper $180.6 \mathrm{~m}$ of section of Site 530 was collected by HPC with an average recovery of $86 \%$. 

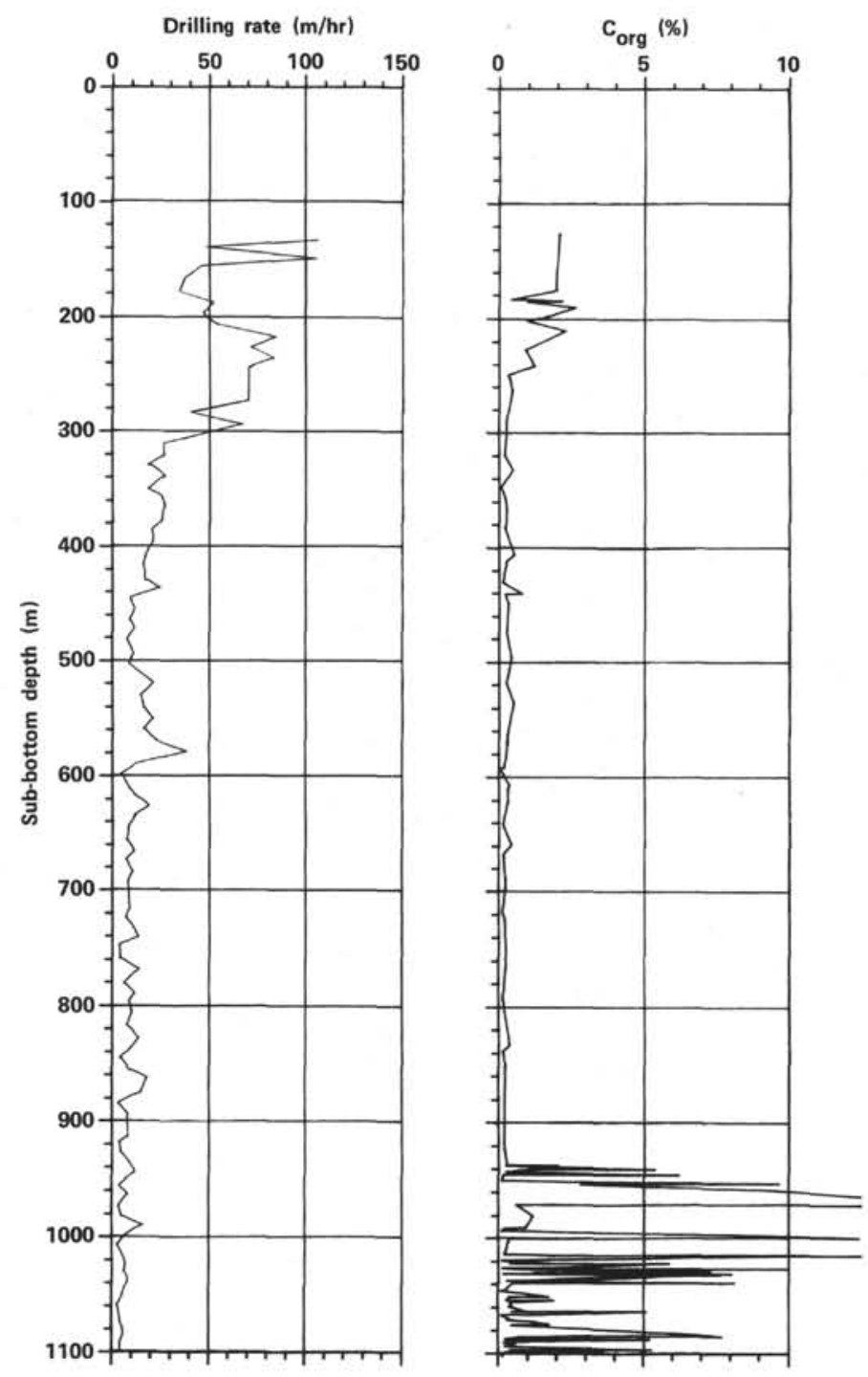

Figure 2. (Continued).

\section{Lithologic Units}

The section recovered in Holes 530A and 530B consists of eight sedimentary units and one basalt unit (Figs. 2 and 3). All but the top of Unit 1 (youngest) was recovered in Hole 530A. All of Unit 1 and the top of Unit 2 was recovered by HPC in Hole 530B (Fig. 3).

The base of the section recovered consists of $19 \mathrm{~m}$ of fine-grained tholeiitic basalt that is the top of basement in this part of the southern Angola Basin (Humphris and Thompson, this volume). The contact between basalt and the overlying red claystone of late Albian-Cenomanian age shows white veins of calcite that extend for a distance of about $5 \mathrm{~cm}$ into the claystone; the claystone appears to be baked for a distance of about $1 \mathrm{~m}$ above the contact. Geochemical data, however, indicate that there has been little or no enrichment of metals in the red claystone that might be attributed to metalliferous hydrothermal solutions (Dean and Parduhn, this

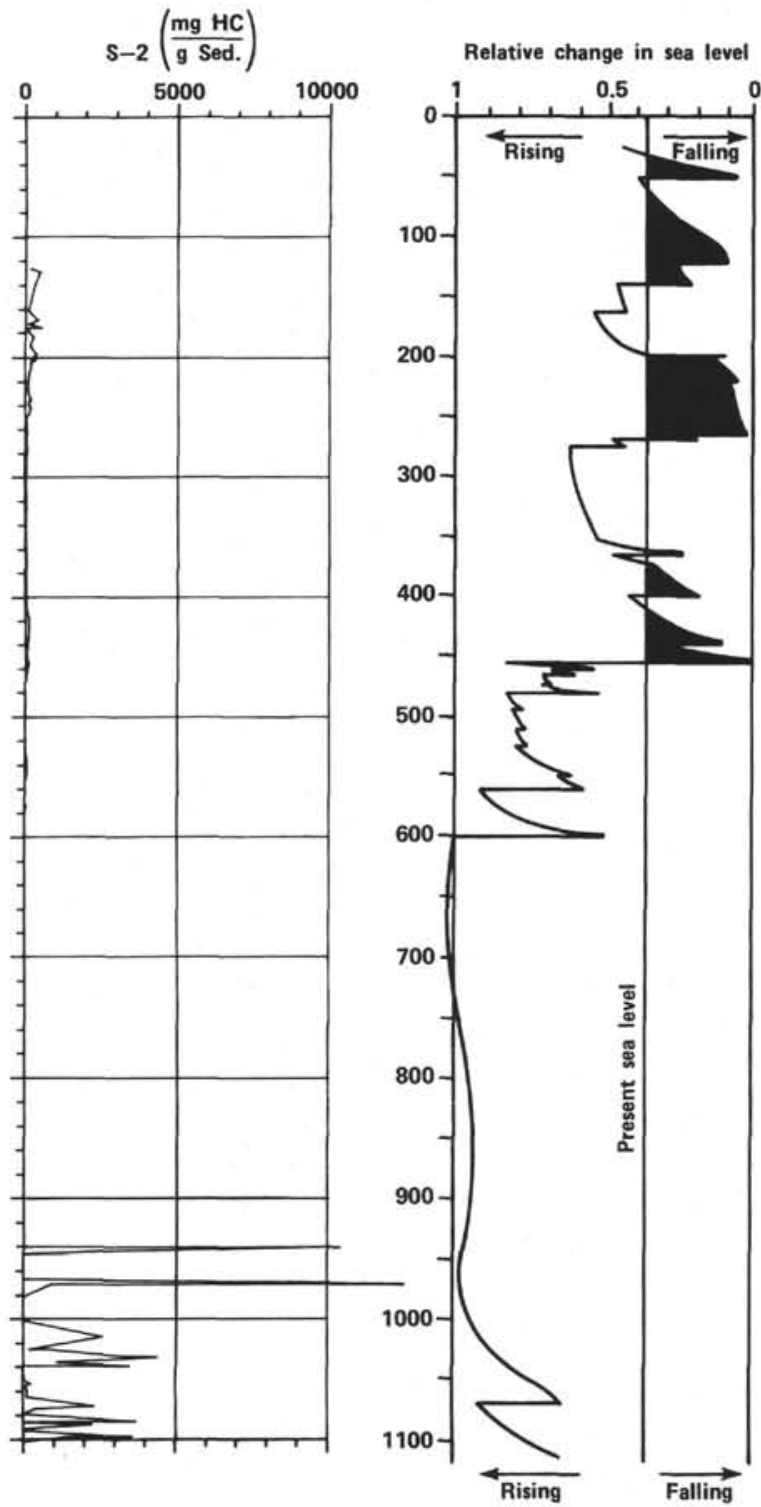

volume). Slight increases in concentrations of $\mathrm{Fe}$ and $\mathrm{Mg}$ and in the $\mathrm{Fe}: \mathrm{Al}$ ratio in claystone just above the basalt contact may result from weathering of basalt.

The lithologic unit overlying basement (lithologic Unit 8) consists of $163 \mathrm{~m}$ of interbedded red and green claystone and black shale of late Albian to Santonian age (Fig. 2). These clay-rich beds had a complex depositional history in a relatively deep (ca. $3.5 \mathrm{~km}$ ), narrow ocean basin by a combination of pelagic, hemipelagic, and turbiditic processes which are difficult to distinguish because of the fine grain size of the strata. The carbonate content of these strata is low but variable (Fig.2) as a result of fluctuations in both the pelagic "rain" of calcareous microfossils and the supply of carbonate from shallower water by turbidity currents. In general, the amount of $\mathrm{CaCO}_{3}$ decreases upward within Unit 8 (Fig. 2), and the concentration of volcanogenic components increases upward (Stow and Miller, this volume). There is little difference in mineralogy between 

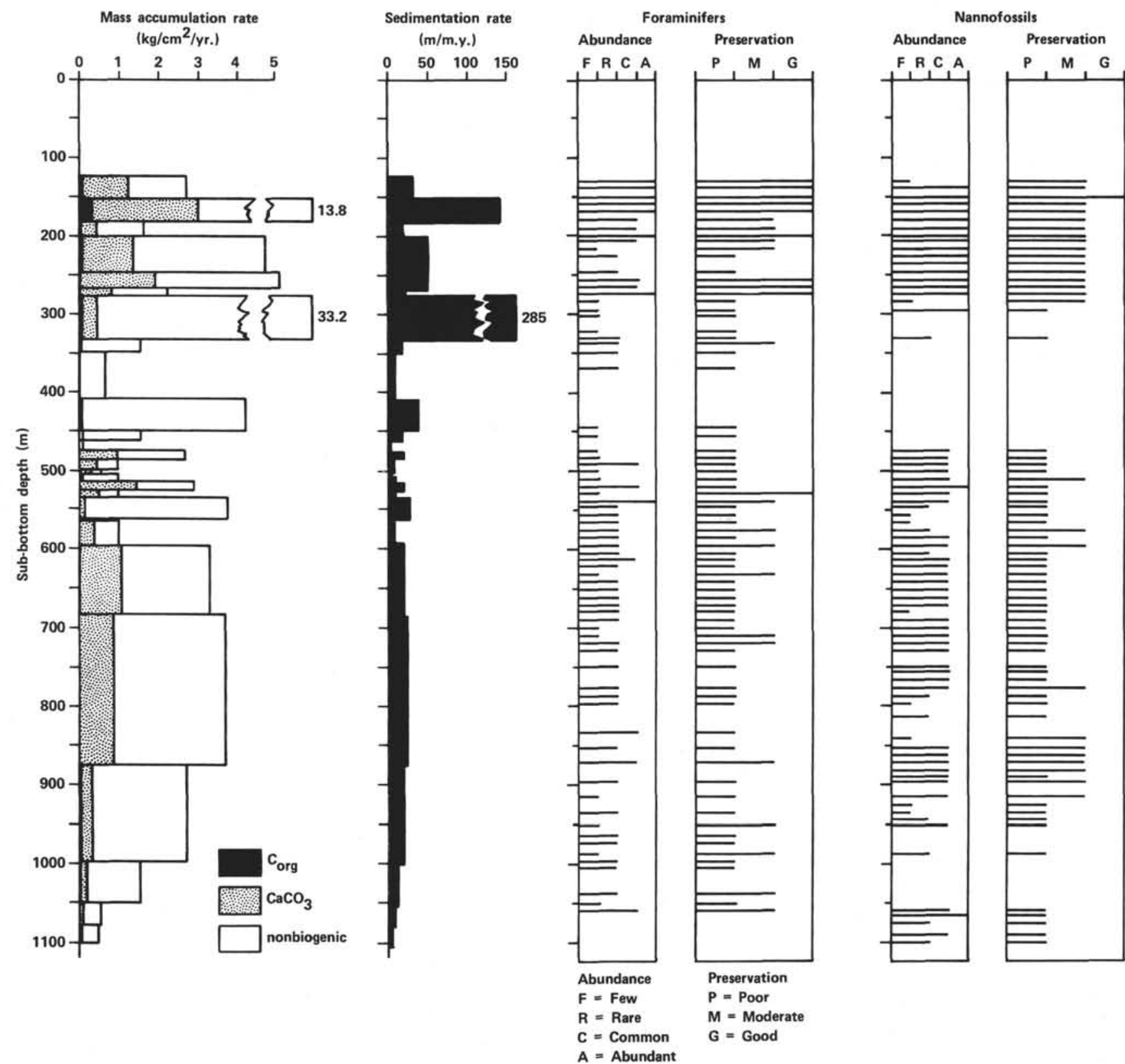

Figure 2. (Continued).

red, green, and black clay-rich lithologies except for the higher concentrations of pyrite in the black shales (Stow and Miller, this volume).

There are 262 beds of black shale in the recovered section of Unit 8 . The average thickness of black-shale beds is about $4 \mathrm{~cm}$ with a range of $<1$ to $62 \mathrm{~cm}$. Most of Unit 8 consists of $<10 \%$ black shale, but in Cores 97 and 98 , about $50 \%$ of the recovered section consists of black shale. The average concentration of organic carbon in black shales is about $5.4 \%$ with a maximum of $19 \%$ (Deroo et al., and Meyers, Brassell, and Huc, this volume).

Lithologic Unit 7 consists of $109 \mathrm{~m}$ of Santonian to lower Campanian red claystone with interbeds of green, red, and purple siltstone and claystone in numerous repeated turbidite sequences (Stow, this volume). The red claystone of Unit 7 is similar to that which is the dominant lithology of Unit 8, except that there is more $\mathrm{Ca}$ $\mathrm{CO}_{3}$, more volcanogenic material, more turbidite sand and silt, and there are no black-shale interbeds.

Lithologic Unit 6 consists of $41 \mathrm{~m}$ of thick (up to 3 $\mathrm{m})$, coarse sandstone turbidites of early Campanian age deposited in channels in the upper part of a submarine fan (Stow, this volume). The sandstone turbidites are composed mainly of altered volcanic fragments cemented with $\mathrm{CaCO}_{3}$.

The lithologies of Units 4 and 5 are highly variable, and include mudstones, marlstones, sandstones, and clastic limestones deposited by turbidity currents in fan lobes and channels (Stow, this volume). The $\mathrm{CaCO}_{3}$ content reflects this variability and ranges from less than $2 \%$ to $97 \%$ (Fig. 2). Unit 5 is $190 \mathrm{~m}$ thick and is Campa- 


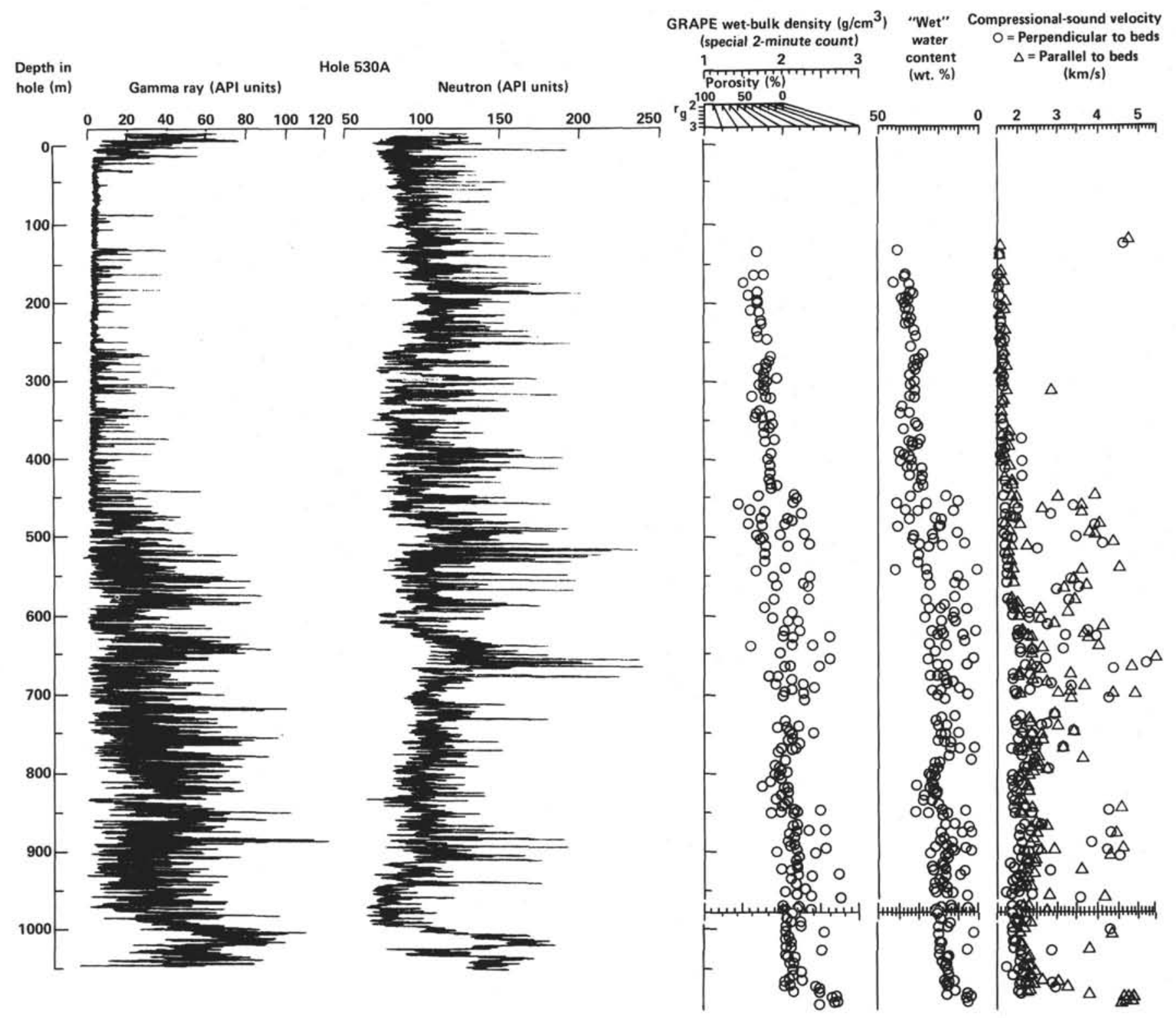

Figure 2. (Continued).

nian to Maestrichtian in age. Unit 4 is $133 \mathrm{~m}$ thick and is late Maestrichtian to Oligocene(?) in age.

Fragments of the large mollusk Inoceramus are present in many cores from the Coniacian to the early Maestrichtian parts of the section, but are most abundant in the upper Campanian to Maestrichtian (Unit 5; Barron et al., this volume). The fragments usually are oriented parallel to stratification and often occur as continuous or partly broken layers across the entire width of the core. Most Inoceramus fragments of Maestrichtian age have a broken gray outer rim of varying thickness in which the calcite has been replaced by silica.

Lithologic Unit 3 consists of $190 \mathrm{~m}$ of red and green claystones of uniform composition deposited below the calcite compensation depth (CCD) during the late Oligocene to late Miocene. The boundary between Units 4 and 3 may represent a major unconformity between the Eocene and Oligocene, or at least the top of Unit 4 and bottom of Unit 3 comprise an extremely condensed Eo- cene to Oligocene section, all within Core 37. This is the only part of the section recovered at Site 530 that does not contain $\mathrm{CaCO}_{3}$, and contains very little evidence of turbidite deposition (Stow, this volume). The homogeneity of Unit 3 is in marked contrast to the highly variable lithologies of the turbidites in underlying Units 4 and 5, and the turbidites and debris-flow deposits of overlying Unit 2. Lithologic Unit 3 corresponds to acoustic Unit 3 (Sibuet et al., this volume). Because of the lithologic homogeneity of this unit, it is acoustically transparent with only a few faint reflectors.

Lithologic Units 1 and 2 consist of $277 \mathrm{~m}$ of turbidites and debris-flow deposits that contain variable mixtures of terrigenous-clastic, siliceous-biogenic, and calcareous-biogenic components (Fig. 3). Unit 2 is late Miocene to early Pleistocene, and Unit 1 is early Pleistocene to Holocene in age. Differences between Units 1 and 2, and within Unit 1 result mainly from variations in these three sediment components; Subunit 1a and 


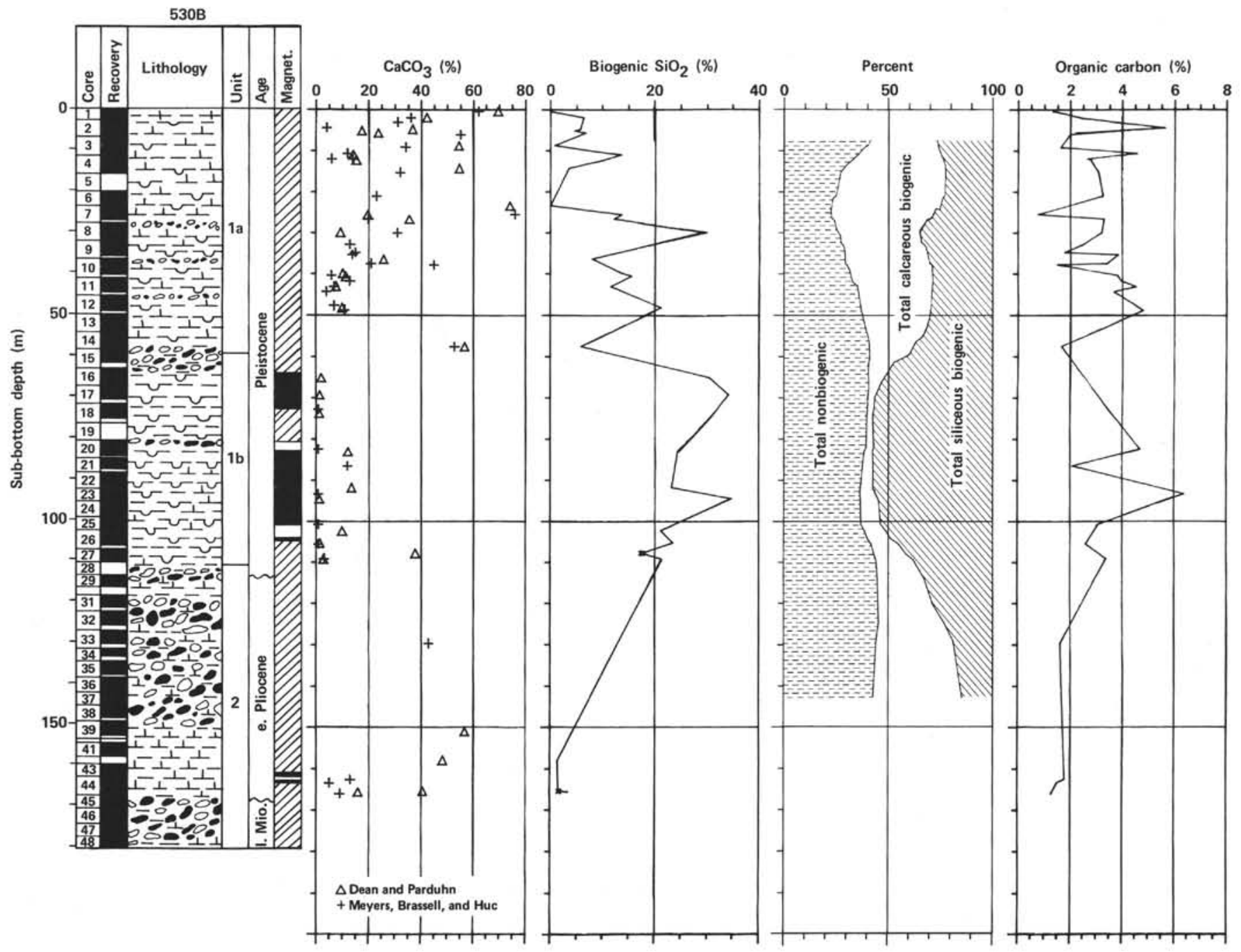

Figure 3. Hole summary chart, Hole 530B, southern Angola Basin. The data for the summary are compiled from the following sources: Percent Ca$\mathrm{CO}_{3}$ from Dean and Parduhn, and Meyers, Brassell, and Huc (this volume); percent total nonbiogenic components, percent total siliceous biogenic components, and percent total calcareous biogenic components from smear-slide estimates in Site 530 chapter (this volume); percent organic carbon from Meyers, Brassell, and Huic (this volume); mass accumulation rates (MARs) of bulk sediment, nonbiogenic components, $\mathrm{CaCO}_{3}$, $\mathrm{SiO}_{3}$, and organic carbon were computed from data in Meyers, Brassell, and Huc, Dean and Parduhn, Steinmetz and Stradner, Stradner and Steinmetz, and Site 530 chapter (all this volume); sedimentation rate from Steinmetz and Stradner, and Stradner and Steinmetz (this volume); wet-bulk density, porosity, water content, compressional sound velocity, and acoustic impedance from Site 530 chapter (this volume).

Unit 2 consist of more or less equal mixtures of all three components, whereas Subunit $1 \mathrm{~b}$ contains abundant siliceous-biogenic debris (Fig. 3), mostly from diatoms that accumulated on Walvis Ridge during peak productivity of the Benguela upwelling system off southwest Africa (Gardner et al., this volume), and were transported to the Angola Basin by turbidity currents and debris flows. The increase in biosiliceous debris in Subunit $1 \mathrm{~b}$ also is indicated by the marked increase in biogenic $\mathrm{SiO}_{2}$ and $\mathrm{Si} / \mathrm{Al}$ ratio (Fig. 3; Dean and Parduhn, and Maillot and Robert, both this volume). As a result of high productivity associated with the Benguela upwelling system, the sediments of lithologic Units 1 and 2 also contain high concentrations (1 to $6 \%$ ) of organic carbon (Fig. 3) that is predominantly of marine origin (Meyers, Brassell, and Huc, this volume). The mode of emplacement of the sediments in Units 1 and 2 has resulted in highly variable sediment accumulation rates
(Figs. 3 and 4) and several major unconformities that correspond to the tops of thick debris-flow deposits (Figs. 3 and 4). These lithologic units correspond to acoustic Unit 4, which is characterized by discontinuous or hummocky reflectors (Sibuet et al., this volume).

\section{Igneous Rocks}

There is very little variation in chemical and petrographic characteristics within the $19 \mathrm{~m}$ of basalt recovered at the bottom of Hole 530A (Humphris and Thompson, this volume). Basalt samples dredged from the northern flank of Walvis Ridge have rare-earth patterns that are different from those of MORBs (Hekinian, 1972). Humphris and Thompson (this volume) also found that the composition of the basalt at Site 530 is distinct from that of typical MORB, but is similar to that of Hawaiian tholeiites and basalt from the central part of Walvis Ridge recovered at Sites 527 and 528. In 

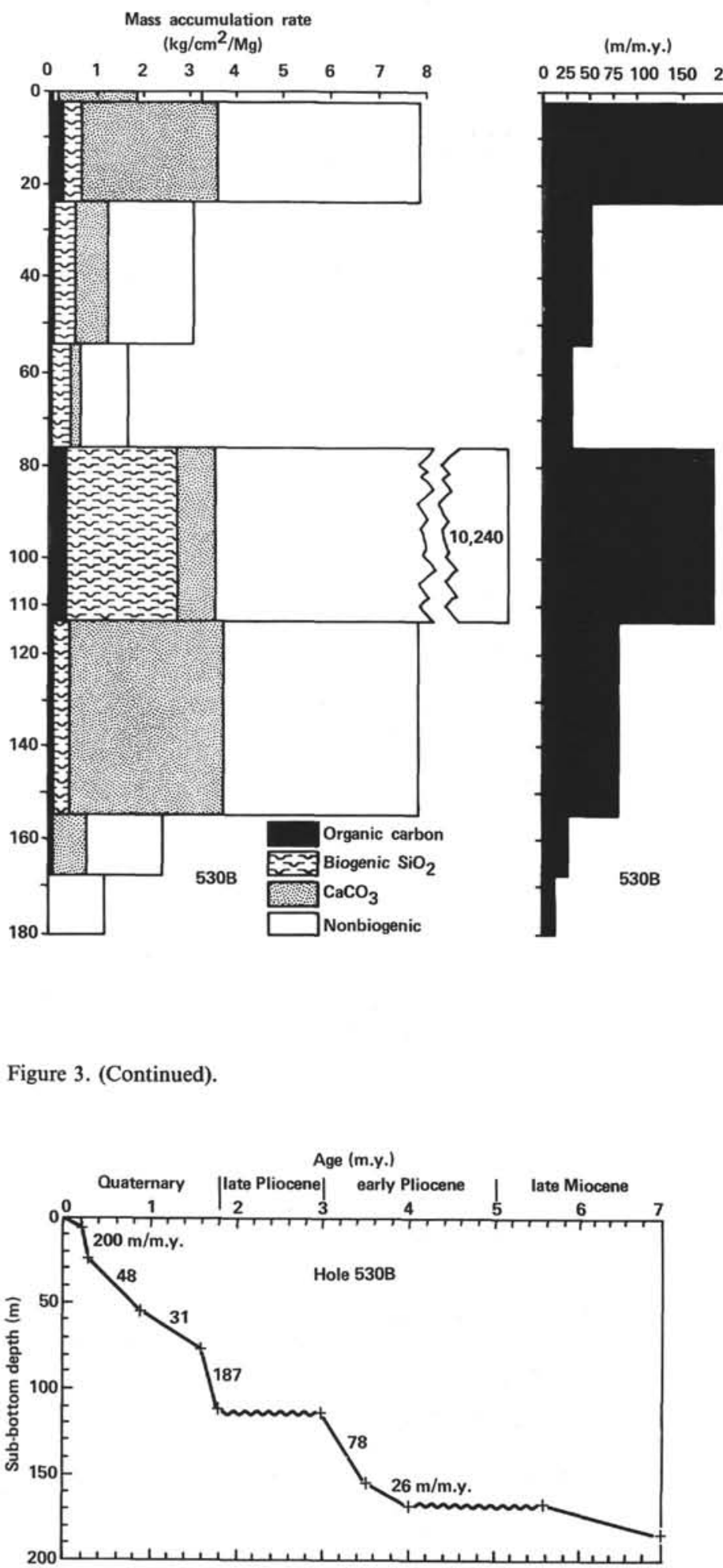

Figure 4. Sedimentation-rate curve for Hole 530B.

particular, the Site 530 basalt is enriched in pyroxene, iron oxides, and incompatible elements such as $\mathrm{Ti}, \mathrm{K}$, $\mathrm{Sr}$, and $\mathrm{Y}$ relative to MORBs (Humpris and Thompson, this volume). These data suggest that the basement in the Angola Basin, at least as far north as Site 530, was

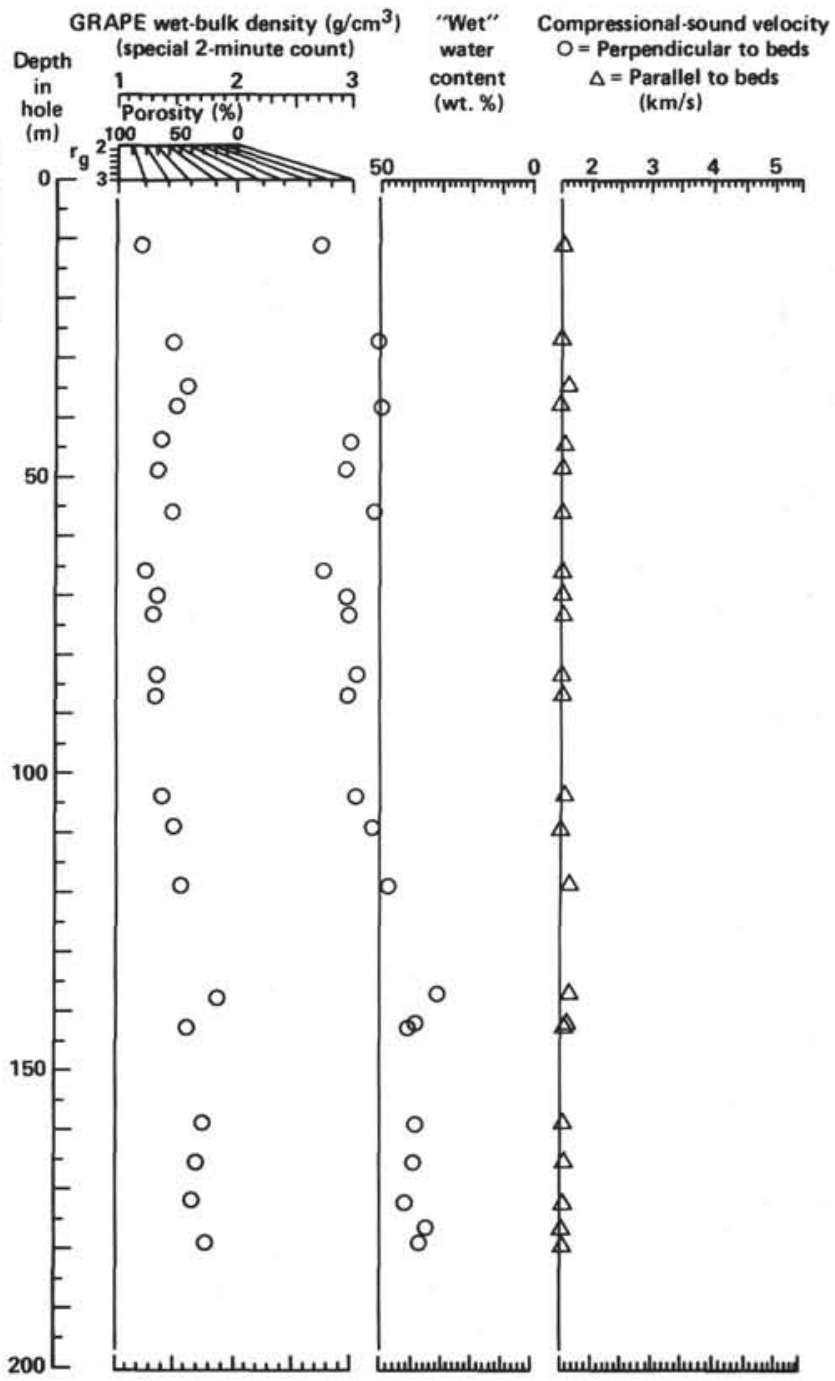

derived from a mantle source that was similar in composition to the source of basalt which forms the central part of Walvis Ridge. Humpris and Thompson (this volume) concluded that the hot spot that created Walvis Ridge had an influence on the composition of the basement at least as far as $20 \mathrm{~km}$ north of the ridge, just as the present hot spot, centered at Tristan da Cunha, has influenced the composition of basalt on the Mid-Atlantic Ridge (Schilling et al., 1981). A modification of the hot spot origin of Walvis Ridge has been proposed by Sibuet et al. (this volume; see also Goslin et al., 1974 and Goslin and Sibuet, 1975). They suggest that the easternmost part of Walvis Ridge is of continental origin and essentially is a structural spur of the African continent. The main part of Walvis Ridge was derived from a mantle hot spot, but the basalt was emplaced along an accretionary spreading center between fracture zones.

The age of basement at Site 530 is not known, but the overlying sediments are at least 92 m.y. (late Cenomanian) and more likely are more than 100 m.y. old (late Albian). Magnetic lineations in basement rocks in the 
vicinity of Site 530 are not distinct. Rabinowitz (1976) and Cande and Rabinowitz (1978) identified magnetic anomaly M4 just south of Walvis Ridge in the Cape Basin and proposed that oceanic crust began to be emplaced north and south of Walvis Ridge during the Barremian to early Aptian (120 to 112 m.y. ago). The basalts at Sites 527 and 528 on the central part of Walvis Ridge are about $68 \mathrm{~m}$.y. old (Moore, Rabinowitz, et al., in press). At Site 524, $15 \mathrm{~km}$ east of the central Walvis Ridge in the Cape Basin, alkalic basalt sills and flows are intercalated with claystones and volcanogenic sandstones of Maestrichtian age (Hsü, LaBrecque, et al., in press). Results from Sites 524, 527, and 528 confirm that the central part of Walvis Ridge formed during the Maestrichtian. The fact that the basalts from Sites 527 and $528(68$ m.y.) are so similar in composition to those from Site 530 suggests that if hot-spot volcanism did form the central part of Walvis Ridge and adjacent Angola Basin, then the hot spot produced basalt of similar composition for at least 25 m.y. (late Cenomanian to Maestrichtian).

\section{Fans, Turbidites, and Debris-Flow Deposits}

The most distinctive characteristic of the entire sedimentary sequence recovered at Site 530 is the abundance of turbidites and debris-flow deposits (Fig. 2). Stow (this volume) recognized three periods of base-of-slope fan development in the strata recovered at Site 530. The oldest of these three fans is the coarsest and comprises about $235 \mathrm{~m}$ of section of Santonian to Campanian age. This period of increased terrigenous sediment influx into the Angola Basin may have been the result of the development of the Benue Trough or Guinea Sea that formed an important connection across North Africa between the Angola Basin and the Tethys seaway from the Turonian to the early Eocene (Reyment and Tait, 1972; Machens, 1973). A considerable amount of sediment was transported from this trough which filled marginal basins with up to $5 \mathrm{~km}$ of Upper Cretaceous marine sediments (McConnell, 1969; Machens, 1973; Adeleye, 1975). Stow referred to this oldest fan as the greenfan facies, because of the thick-bedded (up to $3 \mathrm{~m}$ ), upward-fining, carbonate-cemented, green, volcanogenic sandstones in lithologic Unit 6 . The 41-m-thick sequence of coarse turbidites in Unit 6 are upper-fan channel sandstones, which are the culmination of a coarsening-upward deep-sea fan sequence that began with fine-grained, distal turbidites in Unit 8 (Fig. 2; Stow and Dean, this volume). At least $95 \%$ of Unit 6 is of turbiditic origin and consists mostly of hyaloclastites, basalt fragments, and degraded glass, all in various degrees of alteration to smectite (Stow and Miller, this volume). Because of the abundance of volcanic fragments, the sandstones of Unit 6 contain particularly high concentrations of $\mathrm{Al}, \mathrm{Fe}, \mathrm{Mg}, \mathrm{Na}, \mathrm{Ti}, \mathrm{P}, \mathrm{Co}, \mathrm{Cu}, \mathrm{Cr}, \mathrm{Zr}$, and Sc (Dean and Parduhn, this volume).

The base of the green-fan facies (lithologic Unit 7) consists of thin-bedded siltstone and mudstone turbidites, and the top $95 \mathrm{~m}$ (lithologic Subunit 5c) consists of upward-thinning, medium- to thin-bedded turbidites. Turbidites in the green-fan facies were deposited at an average frequency of about one every 2500 years, for an average sedimentation rate of 2 to $3 \mathrm{~cm} / \mathrm{k}$.y. ( 20 to 30 $\mathrm{m} / \mathrm{m}$.y.; Figs. 2 and 5) (Stow, this volume).

The green-fan facies overlaps with the white-fan facies, which consists of about $225 \mathrm{~m}$ of mudstones, marlstones, and limestones of Maestrichtian to Eocene age (lithologic Units, 4, 5a, and 5b; Fig. 2). Stow (this volume) called this the white-fan facies because it represents the time of maximum relative abundance of carbonate in the southern Angola Basin (Fig. 2). Carbonate fragments of recognizable origin consist of shallow-water fossils, including benthic foraminifers, echinoderms, bryozoans, calcareous algae, mollusks, and lamellibranchs (Stow, this volume). The carbonate debris usually is mixed with volcaniclastics and implies that one or more volcanic islands along Walvis Ridge were emergent and ringed with reefs and carbonate platforms in the Late Cretaceous and early Tertiary. Calcarenites and calcilutites of similar age were recovered at Site 362 and 363 on Walvis Ridge (Bolli, Ryan, et al., 1978). The average sedimentation rate of the white-fan facies is less than 1 $\mathrm{cm} /$ k.y. (10 m/m.y.; Figs. 2 and 5), although individual turbidites which may be "instantaneous" events contain as much as $65 \mathrm{~cm}$ of sediment.

The most recent period of submarine fan deposition in the southern Angola Basin (late Miocene to Recent; Figs. 2 and 3) is represented by the brown-fan facies of Stow (this volume), which comprises about $270 \mathrm{~m}$ of muddy pelagic turbidites and debris-flow deposits. About $25 \%$ of the brown-fan facies consists of debris-flow deposits (Stow, this volume). At least 23 individual debrisflow deposits have been recognized that range in thickness from 0.15 to $32.3 \mathrm{~m}$, and that have a variety of mud, marl, and ooze clasts (Fig. 6) up to at least $60 \mathrm{~cm}$ in diameter in a mud matrix with variable amounts of siliceous- and calcareous-biogenic components. The turbidites were deposited at an average frequency of about one every 25,000 years for an average sedimentation rate of about $3 \mathrm{~cm} / \mathrm{k}$.y. ( $30 \mathrm{~m} / \mathrm{m}$.y.; Figs. 3 and 4$)$. The brown-fan facies corresponds to acoustic Unit 4 (Sibuet et al., this volume). The hummocky reflectors that are characteristic of acoustic Unit 4 are caused by the numerous slumps and flows within the brown-fan facies. Most of the sediment in the brown-fan facies probably came from the south (Walvis Ridge), but isopachs of acoustic Unit 4 suggest that there was a second source to the east (African margin; Sibuet et al., this volume).

The base of the brown-fan facies corresponds to lithologic Unit 2 (Fig. 2) and consists mostly of nannofossil clay and marl in thin-bedded turbiditic units. The middle of the brown-fan facies represents a major slumped unit with a maximum of debris-flow deposits. This was also the period of maximum deposition of siliceous-biogenic debris and organic carbon (lithologic Subunit 1b at Site 530, Figs. 2 and 3, and also lithologic Subunit 1b at Site 532) with high water content and low shear strength (Fig. 3; Site 530, this volume). This may also signal the beginning of flow of AABW into the Angola Basin through the Walvis Channel (Connary and Ewing, 1974). The top of the brown-fan facies roughly corre- 


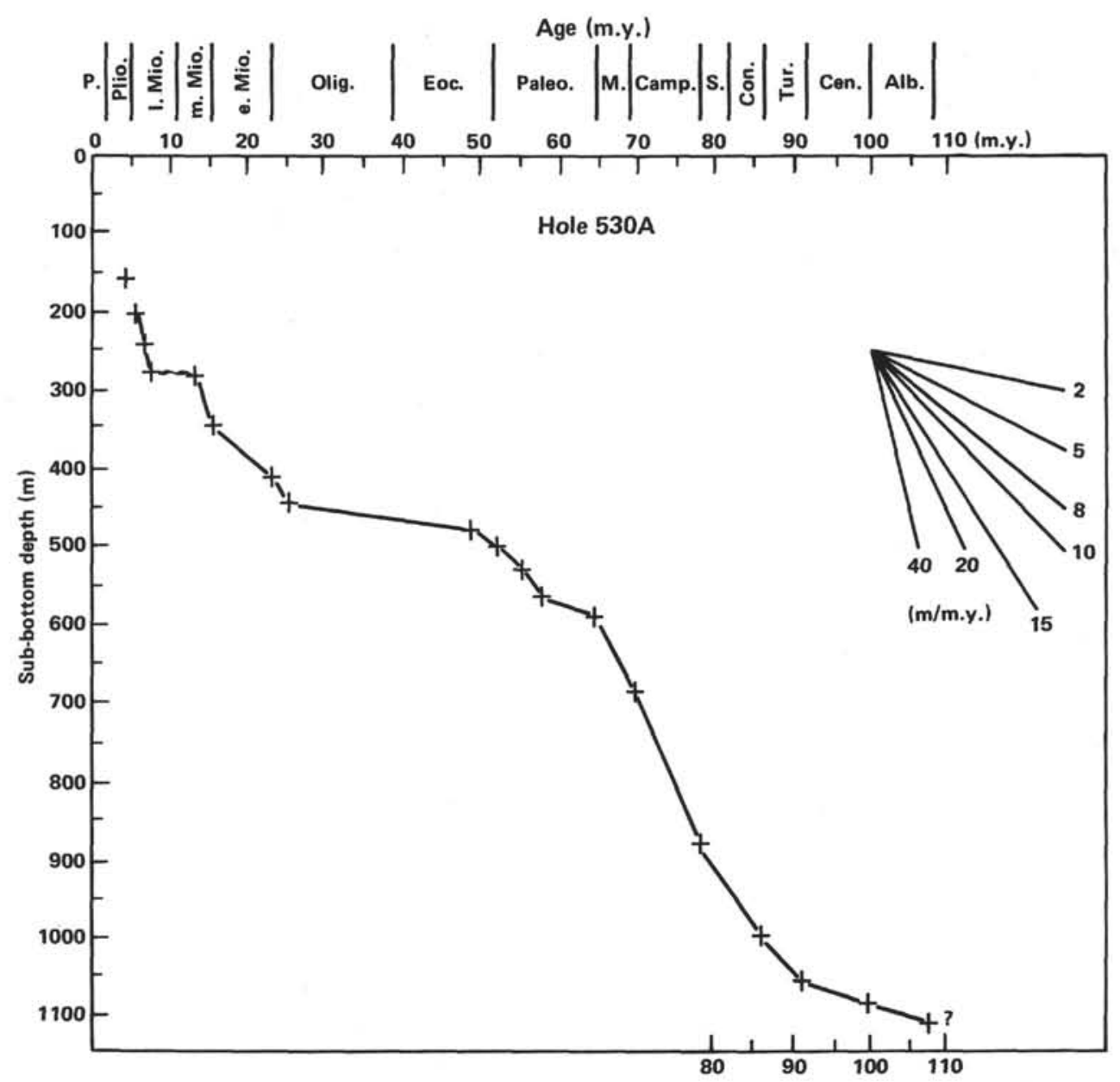

Figure 5. Sedimentation-rate curve for Hole 530A.

sponds to lithologic Subunit 1a and consists of thickbedded turbidites with abundant siliceous- and calcareous-biogenic debris in about equal proportions (Fig. 3).

The major conclusion to be gained from the above discussion is that throughout most of its history, the Angola Basin has received large volumes of redeposited materials as turbidites and, most recently, debris-flow deposits. Turbidites are present throughout the entire section recovered at Site 530, but are least abundant in the Albian to Santonian (lithologic Unit 8) and Oligocene to Miocene (lithologic Unit 3) parts of the section. Much of the redeposited material in the turbidites and debris-flow deposits was derived from Walvis Ridge, with additional material derived from the African continental margin. The most intensive period of turbidite deposition, represented by the green-fan facies, occurred while the southern Angola Basin, and the adjacent African continent, were within a humid to subhumid climatic zone (Fig. 7). As the site moved into the arid subtropical zone, the sedimentation regime shifted to become predominantly basinal. Thus, it appears that broadscale climatic conditions affected the history of continental-margin sedimentation.

\section{Middle Cretaceous Black Shales}

The black-shale beds intercalated with green and red claystones of lithologic Unit 8 provide considerable in- sight into the origin of the middle Cretaceous black shales that have been recovered at many sites in the North and South Atlantic, the Pacific, and on land. The dominant lithology of Unit 8 is red, oxidized, bioturbated claystone (Fig. 8). The claystone of Unit 8 was deposited by a combination of pelagic, hemipelagic, and turbiditic processes, but because the material is fine grained, it is difficult to determine the relative importance of these processes in the deposition of these strata. Stow (this volume) estimated that only about 5 to $20 \%$ of Unit 8 was deposited by turbidity currents as part of a distal fan facies that became coarser later in the middle Cretaceous and culminated in the coarse-sand turbidites of Unit 6 (Campanian; Fig. 2). The bioturbated red claystones, together with the interbedded bioturbated green claystones, comprise about $90 \%$ of Unit 8 . Black shale comprises most of the remaining $10 \%$, although in Cores 97 and 98 it comprises about $50 \%$ of the section (Fig. 8). The important point is that the bioturbated red and green claystones did not accumulate in an anoxic basin, even though the middle Cretaceous South Atlantic was much narrower and more restricted than at present; circulation was sufficient to provide well-oxygenated bottom waters most of the time.

And yet, within the sequence of red and green claystones at Site 530, there are 262 beds of black shale that contain up to $19 \%$ organic carbon (average of about 


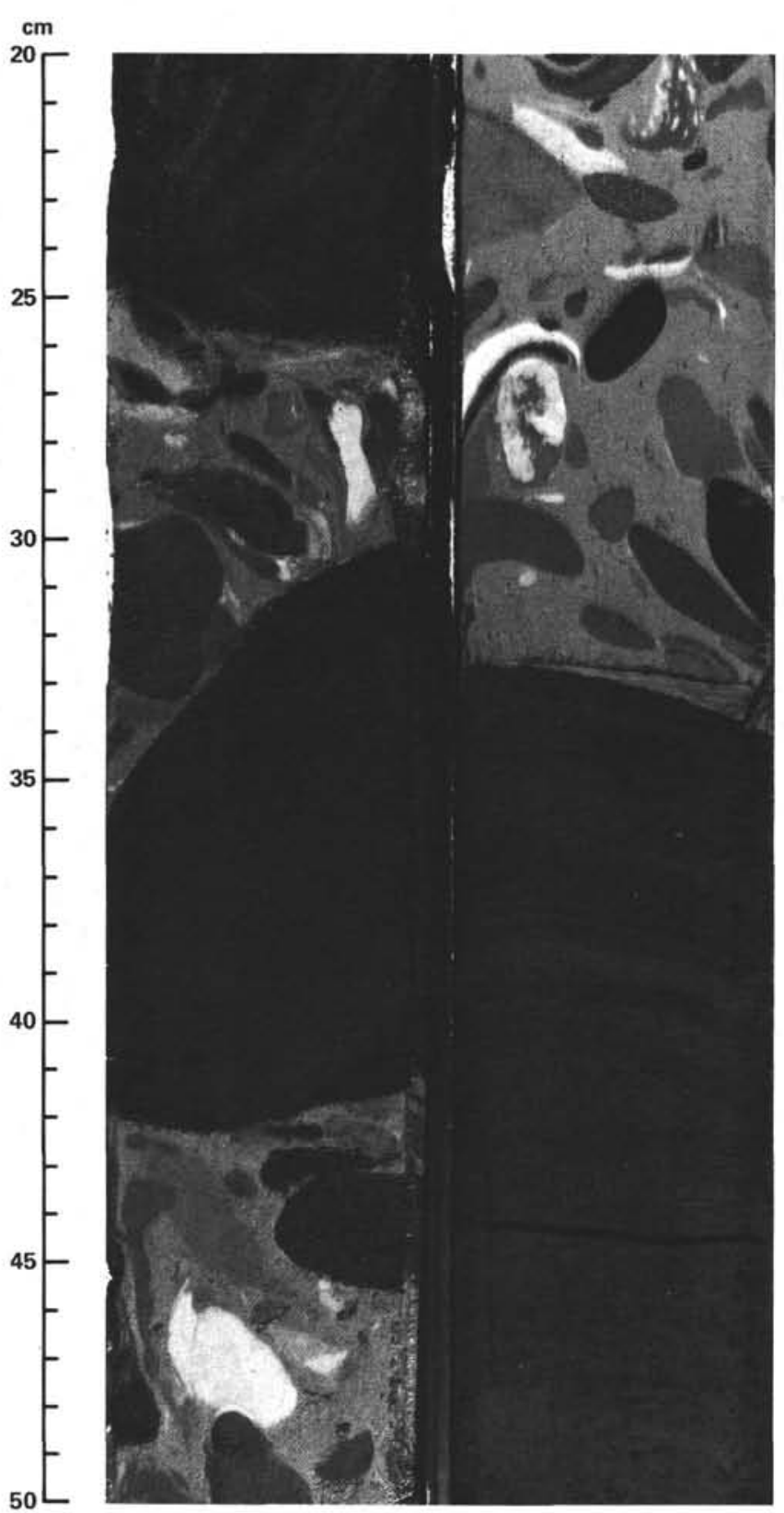

Figure 6. Clasts of varying lithologies in a debris-flow deposit of lithologic Unit $1 \mathrm{~b}(530 \mathrm{~B}-8-1$ and $2,20-50 \mathrm{~cm})$.

$5 \%$; Deroo et al., and Meyers, Brassell, and Huc, both this volume). How did they get there? Do they represent 262 periods of time that the entire water column in the southern Angola Basin became anoxic, or do they record some other circumstance or set of circumstances that permitted the accumulation of organic carbon?

The origin of black shales at Site 530 cannot be considered in isolation from other occurrences of middle Cretaceous organic-carbon-rich strata in the North and South Atlantic (see Dean, Arthur, and Stow, this volume, for a review), and in the Pacific (see Dean et al., 1981 and Thiede et al., 1982, for reviews). These organic-carbon-rich strata are not all strictly synchronous, but were deposited during the middle Cretaceous. There appear to be two separate intervals of maximum accu-

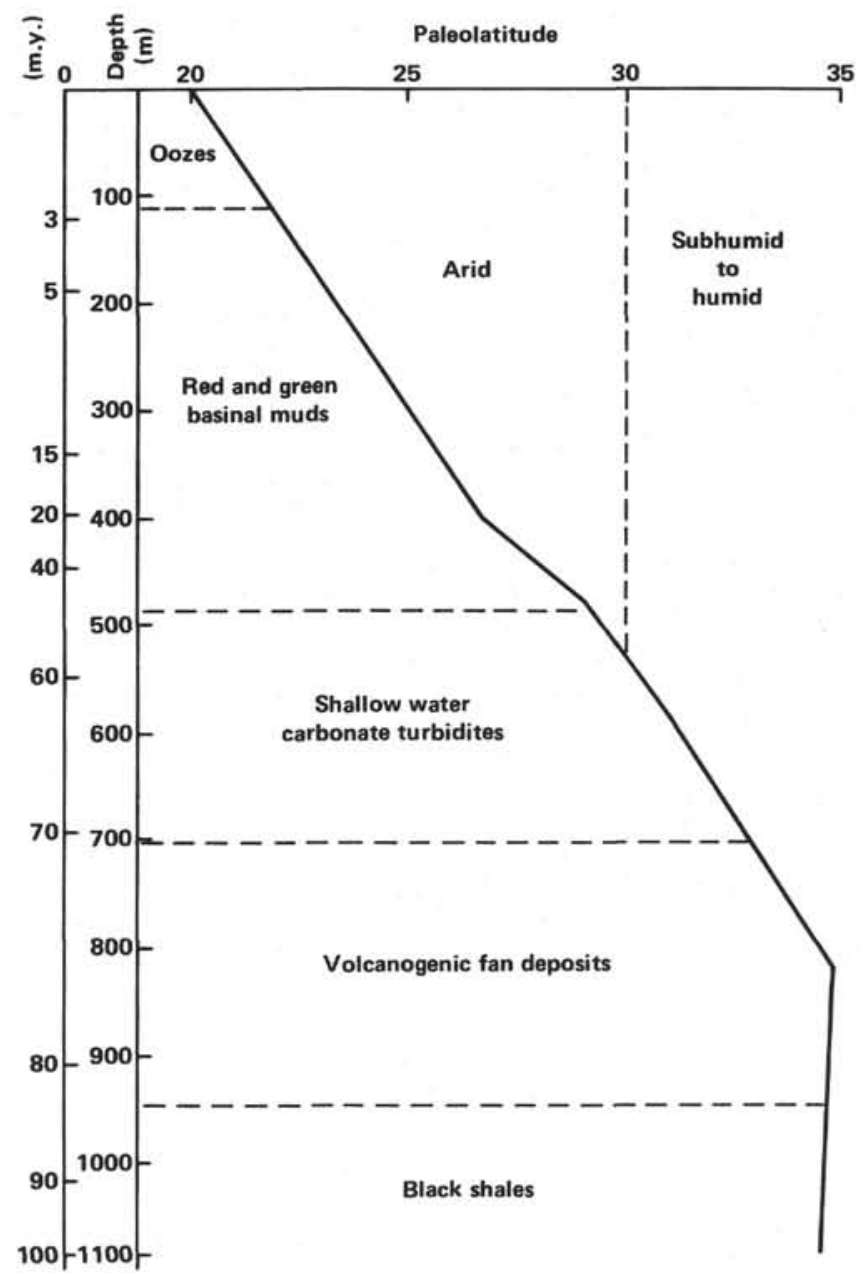

Figure 7. Paleolatitude of deposition of major lithologies encountered at Site 530 .

mulation of organic carbon in the middle Cretaceous (the "Oceanic Anoxic Events" of Schlanger and Jenkyns, 1976 and Jenkyns, 1980), one in the Aptian-Albian and one in the Cenomanian-Turonian. The black shales at Site 530 range in age from late Albian to early Santonian, but the interval of maximum black-shale deposition, Cores 97 and 98 with about $50 \%$ black shale, occurs at the Cenomanian/Turonian boundary (Fig. 8). It is highly unlikely that a coincidence of local conditions of morphometry and circulation in the Angola Basin would have permitted the accumulation of organic carbon at precisely the same time (Cenomanian/Turonian boundary) that high concentrations of organic carbon were accumulating at many different places in the world ocean in a variety of paleobathymetric settings (Schlanger and Jenkyns, 1976; Arthur and Schlanger, 1979).

The origin of middle Cretaceous organic-carbon-rich strata also must be considered within the framework of Cretaceous oceanography and climate, which were much different from those of today. The Aptian evaporites that makeup the base of the marine section in much of the Angola Basin (Bolli, Ryan, et al., 1978; Arthur and Natland, 1979) suggest that the climate must have been very arid. The bittern salts in these evaporites, particularly the mineral tachyhydrite, suggest that the climate 


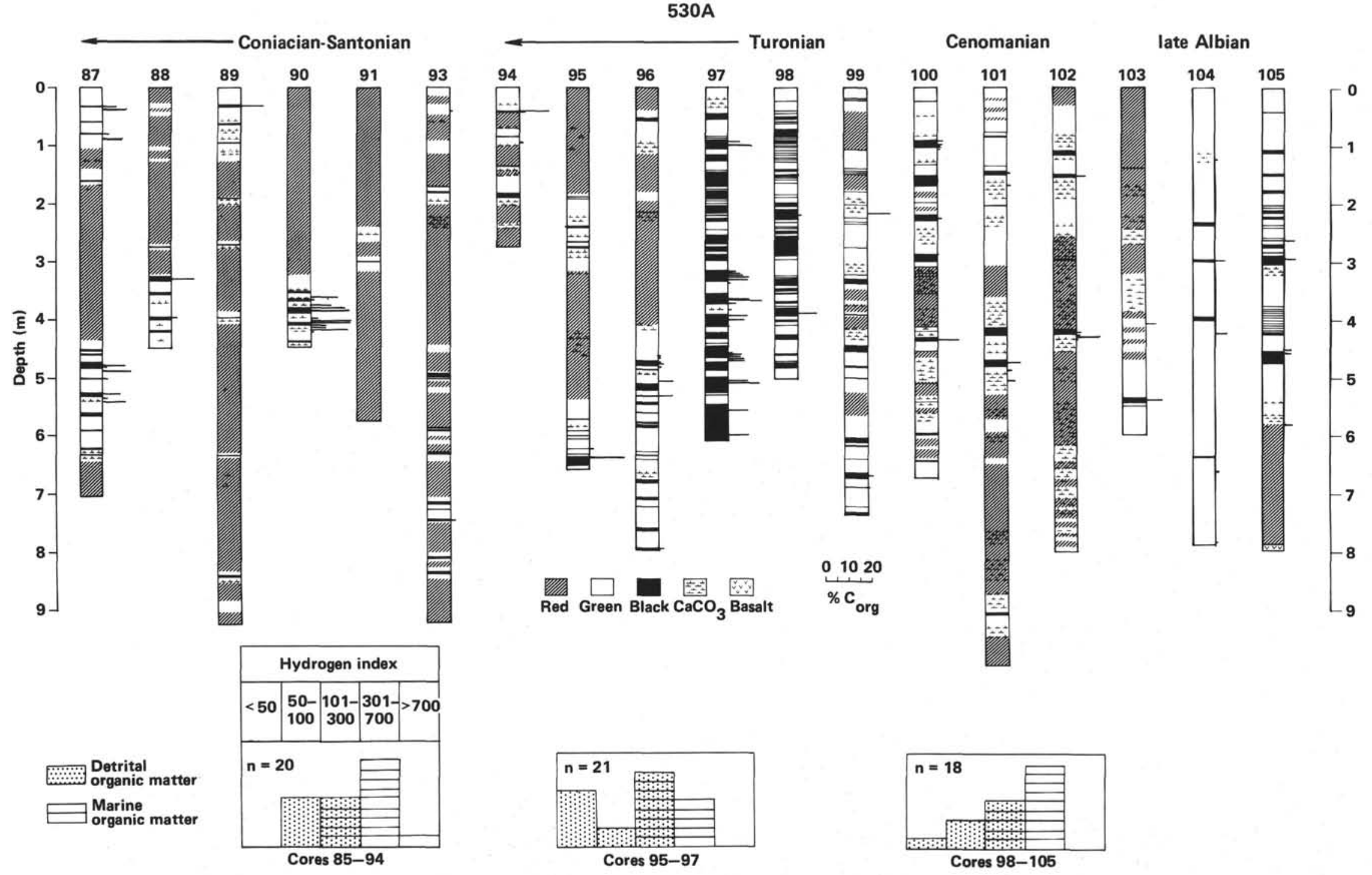

Figure 8. Summary stratigraphic columns of Cores 87 through 105 from Hole $530 \mathrm{~A}$ showing the distribution of red and green claystone, black shale, and CaCO ${ }_{3}$. Concentrations of organic carbon $\left(\mathrm{C}_{\mathrm{org}}\right)$ are indicated by bars to the right of each column; $\mathrm{C}_{\text {org }}$ data are from Deroo et al., and Meyers, Brassell, and Huc (this volume). Histograms of the Rock-Eval hydrogen index for organic matter in Cores 85-94, 95-97, and 98-105 are from Deroo et al. (this volume). 
also was distinctly continental and not characterized by the high humidity of present maritime arid regions of the world (Kinsman, 1976).

The northern part of the Angola Basin was within the arid subtropical zone at the time that the black shales were deposited, but the southern part of the basin was at the latitude of the more humid temperate zone (Fig. 7). Expansion of aridity to the whole basin may have been a result of the location of the basin within the broad continental expanse of rifting Gondwanaland, and of effects of the topography of the uplifted margins of the young ocean basin (Southam and Hay, 1982; Hay et al., 1982).

Eustatic sea levels were much higher during the middle Cretaceous than they are today (Fig. 2), and this produced much larger areas of warm, shallow, highly productive epicontinental seas and drowned continental margins. Global climates were warm and equable, which aided the rapid expansion of terrestrial vegetation. There were, therefore, abundant sources of autochthonous marine and terrestrial organic matter. Crustal spreading rates were relatively fast, and pelagic sediments accumulated rapidly everywhere in the world ocean. Because of the warmer global climate, surface and bottom waters of the ocean were warmer, there was a much smaller difference between surface- and bottom-water temperatures (Douglas and Savin, 1975; Savin, 1977 and 1982; Fischer and Arthur, 1977; Savin and Yeh, 1981; Peterson et al., 1981; Brass, Southam, and Peterson, 1982; Brass, Saltzman, et al., 1982; Wilde and Berry, 1982), and the poles may have been ice free (Thompson and Barron, 1981). Oxygen isotopic paleotemperature measurements on fragments of Inoceramus by Barron et al. (this volume) and Saltzman and Barron (1982) suggest that bottom-water temperatures in the Angola Basin were about $23^{\circ} \mathrm{C}$ at the end of the time of black-shale deposition (Coniacian). Thermohaline circulation is controlled today mainly by the sinking of cold, oxygen-rich surface waters in high latitudes (i.e., vertical circulation is more thermal than haline), but during the Cretaceous, salinity may have been equally important or regionally dominant in vertical mixing (Peterson et al., 1981; Brass, Southam, and Peterson, 1982; Brass, Saltzman, et al., 1982; Wilde and Berry, 1982; Saltzman and Barron, 1982). Because of warmer ocean temperatures, the bottom waters of the Cretaceous ocean must have contained less dissolved oxygen. In fact at certain times during the early and middle Cretaceous, particularly during the Aptian-Albian and Cenomanian-Turonian, most of the ocean below a few hundred meters must have been delicately poised at a low level of dissolved oxygen so that relatively small changes in the flux of oxygen-consuming organic matter or in circulation at any place may have caused anoxia or near anoxia within midwater oxygen-minimum zones and possibly, under extreme conditions, throughout most or all of the bottom-water mass of entire basins.

Some observations regarding the black shales at Site 530 serve to place additional constraints on the origin of the black shale beds, and on the origin of middle Cretaceous black shales in general:
1) The 262 black-shale beds occur within a red and green claystone sequence that records dominantly oxic bottom-water conditions. The average thickness of blackshale beds is only $4.3 \mathrm{~cm}$ (range of $<1$ to $62 \mathrm{~cm}$ ) which suggests that oxygen-deficient conditions in the basin lasted only several thousands to several tens of thousands of years at an average sedimentation rate of about $1 \mathrm{~cm} / \mathrm{k} . \mathrm{y}$.

2) The black-shale beds are interbedded with green claystone or calcareous claystone. About $30 \%$ of the black-shale beds are underlain by light gray limestone or marlstone that grades up into light gray claystone and then into black shale (Stow and Dean, this volume). However, in no case is black shale overlain or underlain directly by red claystone.

3) There is little difference in mineralogy between black, green, and red lithologies in Unit 8 except for the higher abundance of pyrite (mainly as framboids; Schallreuter, this volume) and lower abundance of Ca$\mathrm{CO}_{3}$ in the black shales (Stow and Miller, and Maillot and Robert, both this volume).

4) About $80 \%$ of the black-shale beds are laminated, and about $40 \%$ of the black-shale beds are bioturbated to some degree (Stow and Dean, this volume). Burrows generally are smaller and less abundant in black-shale beds than in the overlying or underlying strata.

5) Very fine-grained, thin-bedded turbidites make up between 5 and $20 \%$ of the section containing the black shales, and they occur in some of the black shales as well as in the interbedded lithologies.

6) At the time the black shales were deposited, the site was several hundred kilometers away from the African continental margin, but probably there was a steep slope between the site and the newly formed Walvis Ridge about $20 \mathrm{~km}$ to the south. Any redeposited sediment, therefore, was more likely derived from Walvis Ridge than from the more distant African continental margin.

7) The organic matter in the black shales consists mainly of amorphous autochthonous marine organic matter, with variable but significant proportions of terrestrial organic matter Brassell; Deroo et al.; Meyers, Brassell, and Huc; Rullkötter et al.; Gilbert; Katz; and Nohara et al., all this volume).

Gilbert (this volume) examined the visual organic components from Site 530 and other South Atlantic DSDP sites. She concluded that black shales and green claystones with $>0.4 \%$ organic carbon contain predominantly amorphous marine kerogen, and that red claystones and green claystones with $<0.4 \%$ organic carbon are rich in terrestrial organic matter. Rullkötter et al. (this volume) estimated that most of the organic matter in the black shales was of marine origin and that the amount of marine organic matter was roughly proportional to the total organic carbon content. Meyers, Trull, and Kawka (this volume) examined the lipid fractions of the strata in Unit 8. They concluded that the lipid fractions contained large amounts of terrestrial components, and that the black shales contained more land-derived lipids than did the interbedded green claystones. However, this probably reflects the better degree 
of preservation (less oxidation) of lipids in the black shale beds relative to the more oxidized green claystone beds. Deroo et al. (this volume), based on detailed Rock-Eval pyrolysis analyses of 45 black-shale beds throughout all of Unit 8, found that they all consist of autochthonous marine organic matter mixed with allochthonous or detrital organic matter. The hydrogen indices (a measure of the amount of autochthonous, lipid-rich organic matter) of samples from black-shale beds in Cores 98 to 105 were mostly $<300$ (Fig. 8), indicative of mostly detrital or allochthonous organic matter. However, samples from black-shale beds in Cores 85 to 97 had higher hydrogen indices (Fig. 8), which suggests that the black shales in the upper part of Unit 8 contain more lipid-rich marine organic matter. In general, the black shales appear to record periods of increased supply and/or preservation of marine organic matter on a background of predominantly terrestrial organic matter as recorded by the red and green claystones (Meyers, Brassell, and Huc, this volume). The variations in type of organic matter as well as in the degree of preservation of the organic matter also is reflected in the highly variable values of $\delta^{13} \mathrm{C}$ of the organic matter (Nohara, et al., this volume).

Deroo et al. (this volume) also found that there were three scales of variation in the amount of marine organic matter in the black-shale beds at Site 530. The smallest scale of variation that they studied was within individual beds (several centimeters to several tens of centimeters). They found that in the beds they studied the amount of marine organic matter was highest in the center of the bed and decreased systematically toward the top and bottom. Within a sequence of black-shale beds interbedded with green claystone (scale of several meters) Deroo et al. found that the amount of organic matter was highest and more marine in the beds in the middle of the sequence. The third scale of organic carbon variation investigated by Deroo et al. was over the entire thickness of Unit 8. In general, they found that the hydrogen index, and hence the relative amount of marine organic matter, increased upward within Unit 8 (Figs. 8 and 9).

In general, the concentrations of many trace elements are higher in black shales in the upper part of Unit 8 than in black shales in the lower part (Fig. 9; Dean and Parduhn, this volume), and this difference may be related to observed differences in type of organic matter. Dean and Parduhn suggested that the differences in trace element concentrations between black shale beds at the bottom and top of Unit 8 might be the result of trace element migration, because preliminary shipboard investigations did not suggest that there were significant differences in type of organic matter within Unit 8. However, the more detailed studies by Deroo et al. (this volume) show that the organic matter in the upper part of the section is more marine. Trace-element variations, therefore, may be related in part to the source of organic matter; that is, the marine organic matter also may be richer in trace elements. That the black shales in the lower part of the section may have more of a terrestrial component is also supported by the clay mineral data (Stow and Miller, this volume), which indicate that the

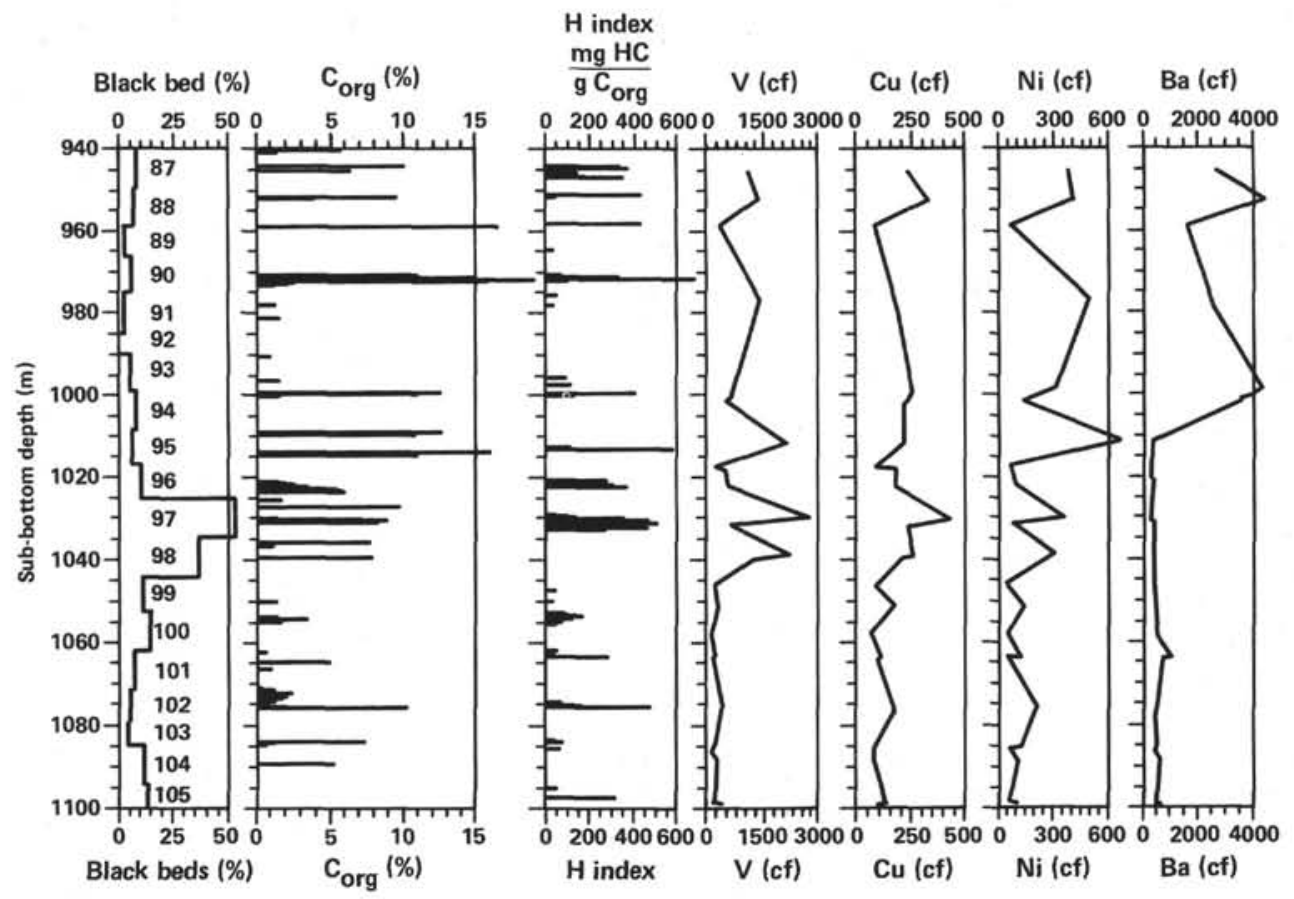

Figure 9. Plots of carbonate-free (cf) concentrations (in parts per million, ppm) versus depth for $\mathrm{V}, \mathrm{Cu}$, $\mathrm{Ni}$, and $\mathrm{Ba}$ in samples of black shale from Cores $87-105$, Hole 530A (from Dean and Parduhn, this volume). The percentage of black-shale beds in each core also is shown. Values of percent organic carbon $\left(\% \mathrm{C}_{\mathrm{org}}\right.$ ) and Rock-Eval hydrogen index (in $\mathrm{mg}$ hydrocarbons per $\mathrm{g}$ organic carbon) are from Deroo et al. (this volume). 
lower part of the section (below Core 98) contains more kaolinite and illite and the upper part of the section (Cores 87 and 97) contains more smectite.

Considering the above observations regarding black shales at Site 530, the widespread occurrences of organic-carbon-rich strata of middle Cretaceous age, and the fact that the Cretaceous oceans were very different from present oceans, Dean, Arthur, and Stow, and Stow and Dean (both this volume) concluded that the origin of interbedded more- and less-reduced lithologies with varying amount of organic matter, and variable amounts of pelagic, hemipelagic, and turbiditic sediments is complex and cannot be explained by any one simple process. One or more of the following factors may have acted to reduce the dissolved oxygen content of bottom waters:

1) The small, silled South Atlantic basin would restrict circulation and tend to produce stratification.

2) The high temperature and salinity of bottom waters would result in a lower concentration of dissolved oxygen.

3) High sea levels would result in a transgression of low-lying land areas and possibly increase the supply of terrestrial organic matter to the continental margin, and also stimulate organic productivity over broad shelves. Both factors would tend to produce poorly oxygenated shelf waters.

4) Increased evaporation over wide shelves would produce dense saline waters (also poor in oxygen) that would tend to spread oxygen-depleted waters to the basin floor and increase salinity stratification.

5) Local restricted shelf basins and coastal lagoons and swamps may have been anoxic and provided sinks for organic matter.

6) Turbid density currents may have transported warm, saline, oxygen-depleted waters as well as organic-carbon-rich sediments to the basin.

The relative importance of these factors varied throughout the middle Cretaceous to produce bottomwater conditions that fluctuated between mildly oxic and oxygen-deficient. Oxygen deficiency probably was greatest within a midwater oxygen minimum zone that would have expanded in depth and become more intense (i.e., lower concentration of dissolved oxygen) as the various factors mentioned above imposed a greater biological oxygen demand on the water column. In extreme cases, when bottom waters were delicately poised at a low oxygen level, the bottom of this oxygen minimum zone expanded to the deepest parts of the basin. The section at Site 530 suggests that bottom waters in the deep Angola Basin became anoxic or nearly anoxic at least 262 times during the middle Cretaceous, but most of the time the bottom-water mass was sufficiently oxic to support at least a benthic epifauna. Also, most of the time the dissolved oxygen concentrations of bottom and sediment interstitial waters were sufficiently high to permit the accumulation of red oxidized sediment.

\section{Cretaceous/Tertiary Boundary}

A relatively complete sedimentary record of the Cretaceous/Tertiary $(\mathrm{C} / \mathrm{T})$ boundary was recovered within the mudstone and marlstone turbidites of lithologic Unit 4 in Hole 530A. Although the lithology is highly variable, and many of the sediments have been reworked and redeposited by turbidity currents, the C/T boundary appears to be well defined on the basis of shipboard biostratigraphic and paleomagnetic data. Samples were therefore collected across the boundary to determine if there were any large geochemical changes in these strata which might indicate that there were major geochemical perturbations of the oceans at that time, and in particular to determine if there was a significant increase in iridium at the boundary that might be attributed to the impact of an asteroid or other extraterrestrial body as suggested by Alvarez et al. (1980 and 1982) and Hsü et al. (1982).

Biostratigraphic data indicate that the $\mathrm{C} / \mathrm{T}$ boundary is about at $50 \mathrm{~cm}$ in Section 2 of Core $530 \mathrm{~A}-50(592.5 \mathrm{~m}$ sub-bottom; Fig. 10; see Steinmetz and Stradner, and Stradner and Steinmetz, both this volume), although there is some mixing of Cretaceous and Tertiary sediments as might be expected in a turbidite sequence. A change from normal to reversed magnetic polarity occurs between 110 and $111 \mathrm{~cm}$ in Section 1, Core 530A-50 (591.6 m sub-bottom). The normal magnetic interval above $591.6 \mathrm{~m}$ is correlated with anomaly 29 (Fig. 10; Keating and Herrero-Bervera, this volume). According to Lowrie et al. (1982) the C/T boundary at Gubbio, Italy, occurs within the magnetic reversed interval just below the base of Anomaly 29. Based on the biostratigraphic and paleomagnetic data therefore, the $\mathrm{C} / \mathrm{T}$ boundary in Hole 530A is somewhere between 591.6+ and $592.5 \mathrm{~m}$ sub-bottom (between $110 \mathrm{~cm}$ in Section 1 and $50 \mathrm{~cm}$ in Section 2, Core 530A-50).

The Upper Cretaceous to lower Tertiary section in Hole 530A consists mainly of interbedded brown and green mudstones and marlstones with highly variable concentrations of $\mathrm{CaCO}_{3}$ (Fig. 10; Site 530 chapter, this volume). Much of the sediment in this sequence was deposited by turbidity currents as part of the "white fan" facies of Stow (this volume). Within Core 530A-50, the Tertiary strata generally contain less than $20 \% \mathrm{CaCO}_{3}$, whereas most of the Cretaceous strata contain between 40 and $60 \% \mathrm{CaCO}_{3}$ (Fig. 10).

Samples for geochemical analyses were collected at 10 -cm intervals in Section 2, Core 530A-50. The samples were analyzed for 10 major and minor elements by Xray fluorescence (XRF) and 31 major, minor, and trace elements by inductively coupled, argon-plasma emission spectrometry (ICP) in the analytical laboratories of the U. S. Geological Survey. Analyses for iridium were by high-precision neutron-activation analysis (Perlman and Asaro, 1969) calibrated against a "Standard Pottery" standard (Perlman and Asaro, 1971) at Lawrence Berkeley Laboratory (Table 1). Results of analyses of the 10$\mathrm{cm}$ samples suggested that there might be an iridium anomaly at about $40 \mathrm{~cm}$ in Section 2, Core 530A-50. Additional samples were therefore collected at 1-cm intervals between 30 and $50 \mathrm{~cm}$ in Section 2, Core 530A50 . Results of analyses of this second group of samples also are included in Table 1. The plus and minus values 


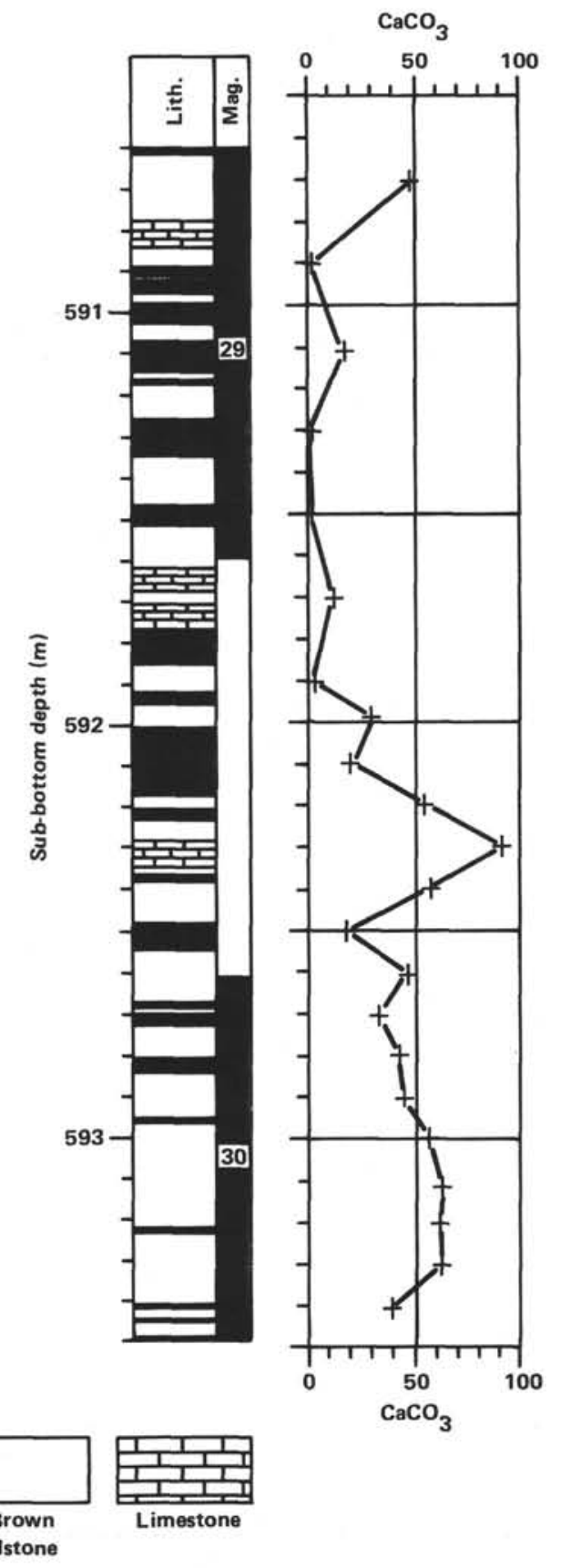

Figure 10. Lithology, paleomagnetics, and percent $\mathrm{CaCO}_{3}$ for $\mathrm{Sec}$ tions 1 and 2, Core 530A-50. Normally magnetized intervals (magnetic Anomalies 29 and 30) are in black; reversed magnetized interval is shown in white.

following the concentration values in Table 1 correspond to plus and minus one standard deviation in the gamma-ray counting statistics.

Results of analyses of major, minor, and trace elements by XRF and ICP, computed on a carbonate-free basis, are plotted versus sub-bottom depth in Figure 11. For purposes of converting the raw data to carbonatefree concentrations, the calcium concentration measured by XRF was taken as a measure of percent $\mathrm{CaCO}_{3}$ (Fig. 10; see Dean and Parduhn, this volume, for method of calculation). By comparing Figures 10 and 11, it is ap-
Table 1. Concentration of iridium (in parts per billion, ppb) in samples from Core 530A-50, Section 2. The indicated errors in iridium concentration $( \pm)$ are the estimated precisions of measurement expressed as one standard deviation of the counting of gamma rays following activation by neutron irradiation. Data were supplied by F. Asaro, $\mathrm{H}$. V. Michel, W. Alvarez, and L. W. Alvarez of Lawrence Berkeley Laboratories and the University of California.

\begin{tabular}{|c|c|c|}
\hline $\begin{array}{l}\text { Interval } \\
(\mathrm{cm})\end{array}$ & $\begin{array}{l}\text { Sub-bottom } \\
\text { depth } \\
\text { (m) }\end{array}$ & $\begin{array}{c}\text { Iridium } \\
\text { (ppb) }\end{array}$ \\
\hline $10-11$ & 592.105 & $-.35 \pm .33$ \\
\hline $20-21$ & 592.205 & $.36 \pm .28$ \\
\hline $30-31$ & 592.305 & $-.11 \pm .29$ \\
\hline $32-33$ & 592.325 & $.28 \pm .09$ \\
\hline $34-35$ & 592.345 & $.15 \pm .06$ \\
\hline $36-37$ & 592.365 & $.06 \pm .08$ \\
\hline $37-38$ & 592.375 & $.39 \pm .05$ \\
\hline 38 & 592.380 & $.15 \pm .10$ \\
\hline $38-39$ & 592.385 & $.09 \pm .12$ \\
\hline 39 & 592.390 & $.02 \pm .08$ \\
\hline $39-40$ & 592.395 & $.22 \pm .07$ \\
\hline 40 & 592.400 & $.10 \pm .09$ \\
\hline $40-41$ & 592.405 & $.30 \pm .11$ \\
\hline 41 & 592.410 & $.08 \pm .09$ \\
\hline $41-42$ & 592.415 & $.20 \pm .08$ \\
\hline 42 & 592.420 & $-.02 \pm .08$ \\
\hline $42-43$ & 592.425 & $.29 \pm .08$ \\
\hline 43 & 592.430 & $.03 \pm .07$ \\
\hline $43-44$ & 592.435 & $.00 \pm .09$ \\
\hline 44 & 592.440 & $.10 \pm .10$ \\
\hline $44-45$ & 592.445 & $.30 \pm .17$ \\
\hline 45 & 592.450 & $-.12 \pm .08$ \\
\hline 46 & 592.460 & $.09 \pm .09$ \\
\hline $46-47$ & 592.465 & $.12 \pm .10$ \\
\hline $48-49$ & 592.485 & $-.41 \pm .21$ \\
\hline $50-51$ & 592.505 & $.28 \pm .22$ \\
\hline $60-61$ & 592.605 & $.04 \pm .18$ \\
\hline $70-71$ & 592.705 & $-.13 \pm .26$ \\
\hline $80-81$ & 592.805 & $.00 \pm .18$ \\
\hline $90-91$ & 592.905 & $-.14 \pm .21$ \\
\hline $100-101$ & 593.005 & $-.08 \pm .19$ \\
\hline $110-111$ & 593.105 & $-.29 \pm .16$ \\
\hline $120-121$ & 593.205 & $.00 \pm .15$ \\
\hline $130-131$ & 593.305 & $.03 \pm .11$ \\
\hline $140-141$ & 593.405 & $-.27 \pm .23$ \\
\hline
\end{tabular}

parent that concentrations of strontium, manganese, and, to a lesser extent, magnesium are contained mostly in the carbonate fraction. Note that the curves for these three elements in Figure 11 are parallel to the curve for $\mathrm{CaCO}_{3}$ in Figure 10.

Concentrations of 13 other elements $(\mathrm{B}, \mathrm{Co}, \mathrm{Cr}, \mathrm{Ga}$, $\mathrm{Sc}, \mathrm{V}, \mathrm{Zn}, \mathrm{Zr}, \mathrm{Dy}, \mathrm{Er}, \mathrm{Nb}, \mathrm{Sm}$, and Y) do not appear to be associated with the carbonate fraction (their concentration versus depth plots do not parallel that of $\mathrm{Ca}$ $\mathrm{CO}_{3}$, and their concentrations are negatively correlated with that of $\mathrm{CaCO}_{3}$ ), but are all high in the limestone bed between 592.29 and $592.36 \mathrm{~m}$ (Figs. 10 and 11). The concentrations of most of these 13 elements between 592.2 and $592.4 \mathrm{~m}$ are well above the carbonate-free baseline 

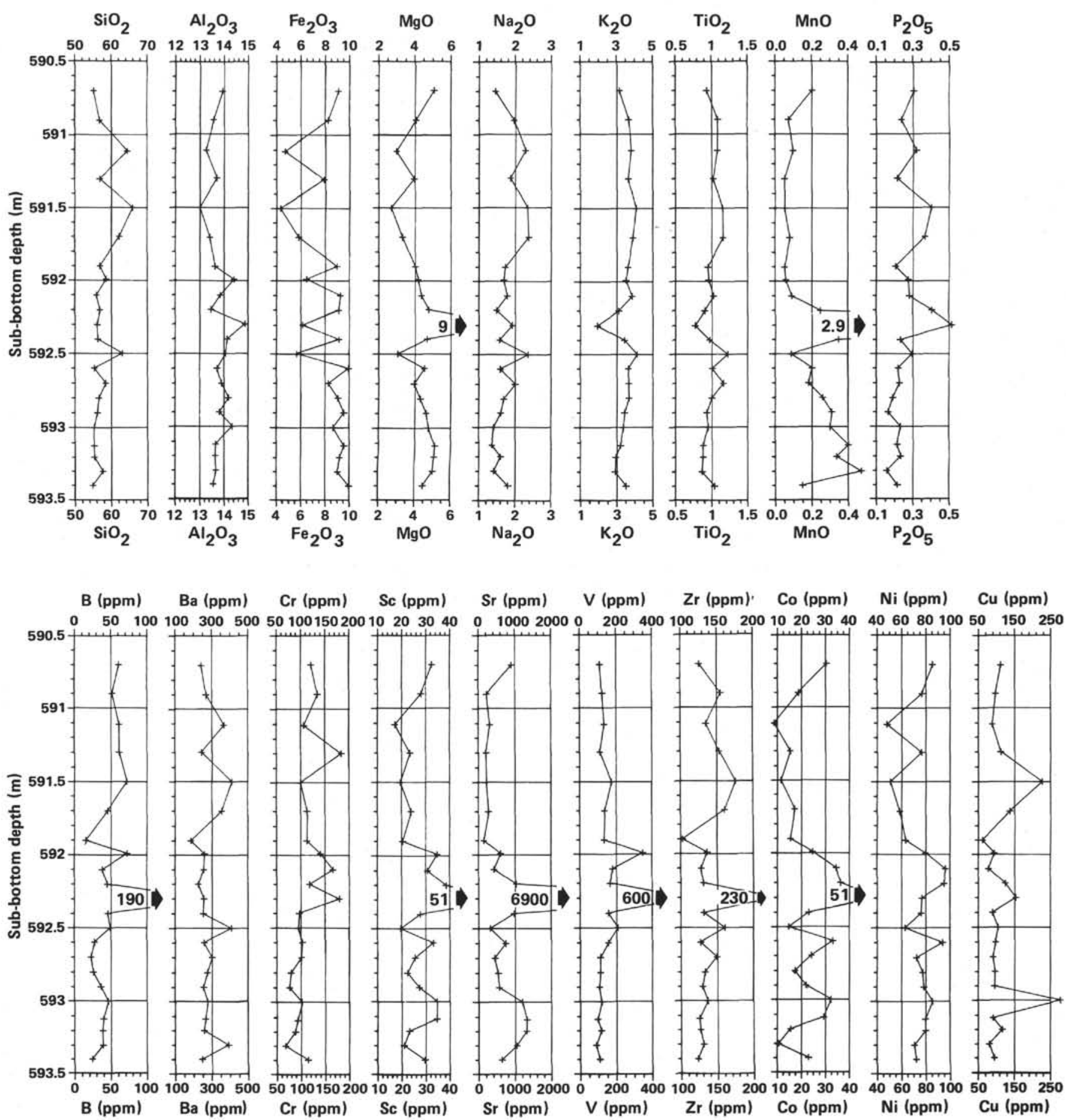

Figure 11. Plots of carbonate-free concentrations of major and minor element oxides, in percent, and of trace elements, in parts per million (ppm), versus depth for Sections 1 and 2, Core 530A-50.

concentrations of the strata in the rest of Core 50 (Fig. 11 ) and in fact are higher than concentrations of these elements in most of the stratigraphic sequence recovered in Hole 530A (see Dean and Parduhn, this volume). Concentrations of a few elements (e.g., $\mathrm{Co}, \mathrm{Pb}$, and $\mathrm{V}$ ) are as high as concentrations of the same elements in middle Cretaceous black shales recovered in Hole 530A (Dean and Parduhn, this volume).
Table 1 shows that most samples between 32 and 43 $\mathrm{cm}$ within Section 2, Core 530A-50 (592.32 and 592.43 $\mathrm{m}$ sub-bottom) contain concentrations of iridium that are above background levels and are higher than two standard deviations of the gamma-ray counting statistics. The highest iridium concentration $(0.39 \pm 0.05$ ppb) occurs in a brown marlstone bed that underlies a light greenish gray sandy limestone bed (592.29 to 

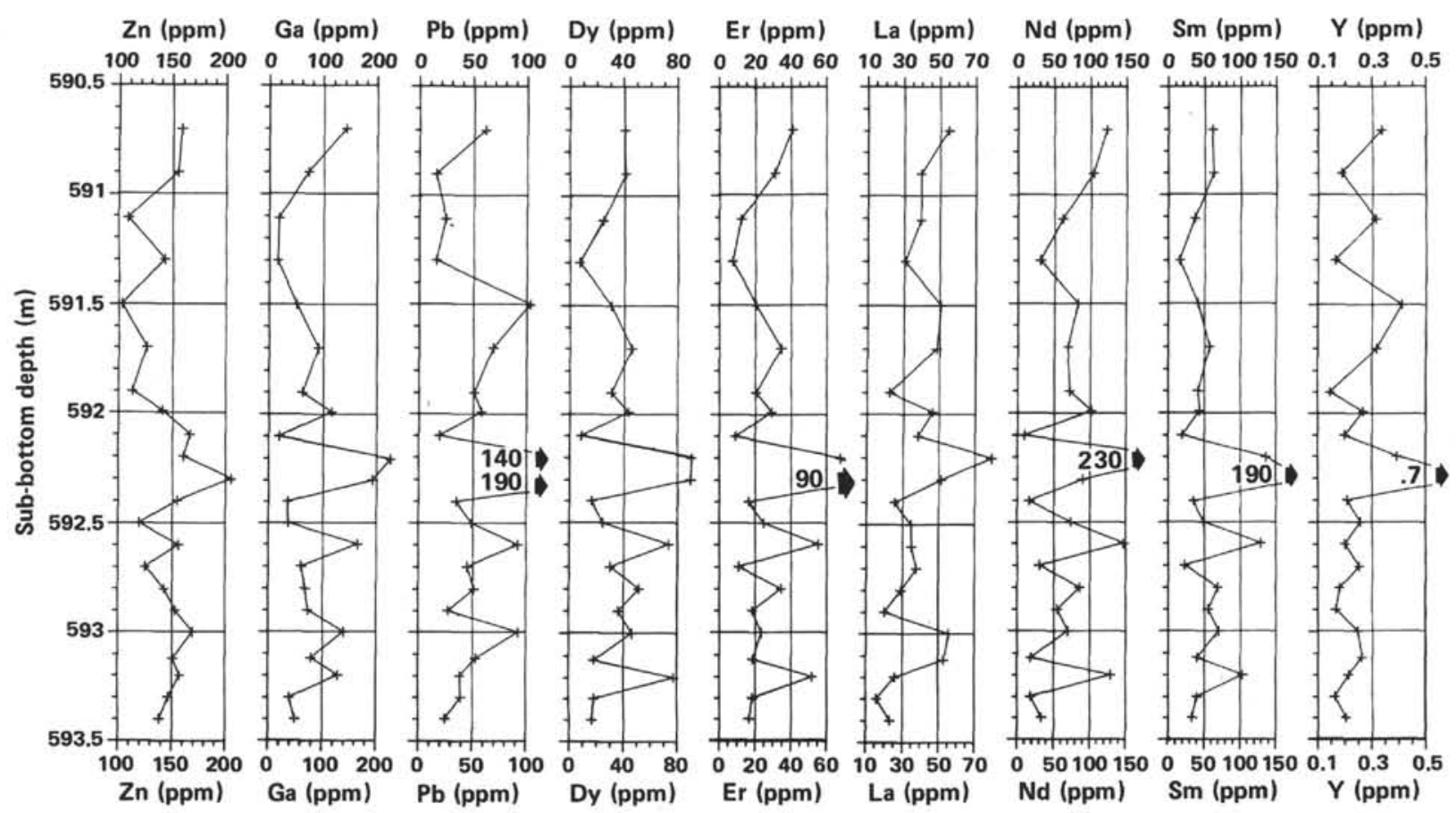

Figure 11. (Continued).

$592.36 \mathrm{~m}$ sub-bottom). Most other samples with elevated concentrations of iridium also are from brown marlstone underlying the sandy limestone, although two samples of the limestone bed also contain elevated concentrations of iridium.

The data in Table 1 indicate that there is a definite anomaly in the concentration of iridium across the $\mathrm{C} / \mathrm{T}$ boundary at Site 530. Because most of the material in the Upper Cretaceous to lower Tertiary strata at Site $\mathbf{5 3 0}$ was derived from shallow water and redeposited by turbidity currents, the iridium anomaly has been affected by reworking. The anomaly is therefore "smeared out" over a wider time range than it might have been if the iridium had accumulated in a pelagic sequence. Also, the intensity of the anomaly probably has been diminished by dilution with older sediment having a low iridium concentration.

The occurrence of high concentrations of many other elements within the same stratigraphic interval as the iridium anomaly suggests that these elements may have been concentrated by the same processes by which iridium was concentrated. Furthermore, the marked decrease in $\mathrm{CaCO}_{3}$ in the Tertiary strata above the iridium anomaly suggests that the production of shallow-water carbonate material also may have been affected by whatever caused elevated concentrations of iridium and other elements. All of these observations are consistent with the asteroid-impact theory proposed to explain the worldwide occurrence of an iridium anomaly at the C/T boundary (Alvarez et al., 1980 and 1982).

\section{Carbonate Compensation and Cenozoic Paleoceanography of the Angola Basin}

The Cenozoic history of the Angola Basin was controlled mainly by: (1) restriction of the basin to bottomwater flow from the south by the Walvis Ridge; (2) de-

velopment of glaciation on Antarctica and, in the late Cenozoic, in the northern hemisphere; (3) opening of circulation passages in the southern oceans; (4) rapid turnover of cold, nutrient-rich waters and resulting high productivity of siliceous organisms in polar latitudes; (5) influx of terrigenous sediments and their dispersal mainly by turbidity currents; and (6) production and preservation of carbonate sediment.

The major Cenozoic events in the Angola Basin, as recorded in the sections recovered at Sites 364 and 530, are outlined in Table 2. The Maestrichtian to lower Eocene sections at Sites 364 and 530 record a period of increased relative abundance of $\mathrm{CaCO}_{3}$ in the Angola $\mathrm{Ba}$ sin (Figs. 2 and 12). The sedimentation rate during this period was fairly slow ( $<25 \mathrm{~m} / \mathrm{m}$.y.; Figs. 2 and 5), so that the mass accumulation rate of $\mathrm{CaCO}_{3}$ was still low (mostly $<1 \mathrm{~kg} / \mathrm{cm}^{2} / \mathrm{m}$.y.; Fig. 2). Much of the carbonate that accumulated in the Angola Basin during this time was derived from shallow-water sources and transported by turbidity currents to form the white-fan facies of Stow (this volume). Pelagic calcareous microfossils are poorly preserved (Fig. 2). These observations suggest that the increased relative abundance of carbonate in the Maestrichtian to lower Eocene was the result of a decrease in dilution by terrigenous clastics rather than an increase in the production of pelagic carbonate. The decrease in terrigenous clastics probably resulted from a combination of a decrease in the influx of terrigenous clastics from the Benue Trough (McConnell, 1969; Reyment and Tait, 1972; Machens, 1973; Adeleye, 1975), and the fact that the area had moved from a midlatitude humid climatic zone to an arid subtropical climatic zone (Fig. 7).

The end of the early Eocene is marked at Site 530 by a drastic decrease in carbonate content of the sediments, and either an unconformity or an extremely compressed 
Table 2. Outline of timing of events in the Cenozoic history of the Angola Basin, and paleoceanographic and paleoclimatic events elsewhere in the world.

\begin{tabular}{|c|c|c|}
\hline Age & Event: Angola Basin & $\begin{array}{l}\text { Paleoceanographic or } \\
\text { paleoclimatologic event }\end{array}$ \\
\hline $\begin{array}{l}\text { early Pleistocene } \\
\qquad(1.0 \text { to } 1.8 \mathrm{~m} . \mathrm{y} .)\end{array}$ & $\begin{array}{l}\text { Low accumulation of } \mathrm{CaCO}_{3} ; \text { maximum } \\
\text { accumulation of diatoms }\end{array}$ & Shoaling of the CCD \\
\hline $\begin{array}{l}\text { late Pliocene ( } 1.8 \\
\text { to } 3.0 \text { m.y.) }\end{array}$ & Unconformity at top of debris-flow deposit & $\begin{array}{l}\text { Development of northern hemisphere glaciation } \\
\text { (Shackleton and Kennett, 1974b; Shackle- } \\
\text { ton and Opdyke, 1977) }\end{array}$ \\
\hline $\begin{array}{l}\text { early Pliocene to } \\
\text { late Miocene (4 } \\
\text { to } 5.6 \text { m.y.) }\end{array}$ & $\begin{array}{l}\text { Unconfomity at top of debris-flow deposit in } \\
\text { Hole } 530 \mathrm{~B} \text {; large increase in mass accumu- } \\
\text { lation rate of } \mathrm{CaCO}_{3} \text { and nonbiogenic } \\
\text { material in Hole } 530 \mathrm{~A}\end{array}$ & $\begin{array}{l}\text { Development of a thick Antarctic ice sheet } \\
\text { (Shackleton and Kennett, 1974a); drop in } \\
\text { sea level; development of Antarctic Bottom } \\
\text { Water (Frakes and Kemp, 1972) }\end{array}$ \\
\hline $\begin{array}{l}\text { middle to late } \\
\text { Miocene ( } 7.5 \text { to } \\
13 \text { m.y.) }\end{array}$ & $\begin{array}{l}\text { Unconformity; large increase in accumulation } \\
\text { of } \mathrm{CaCO}_{3} \text {; poor preservation of foramini- } \\
\text { fers but nannofossils well preserved }\end{array}$ & $\begin{array}{l}\text { Sharp drop in CCD in most ocean basins of } \\
\text { the world; beginning of a major ice cap on } \\
\text { Antarctica ( } 10 \text { to } 13 \mathrm{~m} . \mathrm{y} \text {. ago) with forma- } \\
\text { tion of pre-AABW (McCoy and Zimmer- } \\
\text { man, 1977); sharp drop in sea level }\end{array}$ \\
\hline $\begin{array}{l}\text { late Oligocene to } \\
\text { middle Eocene } \\
(26 \text { to } 49 \text { m.y.) }\end{array}$ & $\begin{array}{l}\text { Unconformity or highly compressed section } \\
\text { with several beds of } \mathrm{CaCO}_{3} \text {-cemented } \\
\text { conglomerate }\end{array}$ & $\begin{array}{l}\text { Active bottom currents with deep-sea erosion } \\
\text { (Kennett et al., 1974); high productivity } \\
\text { and accumulation of } \mathrm{CaCO}_{3} \text { in the Pacific. } \\
\text { Major global cooling; sharpening of latitu- } \\
\text { dinal temperature gradients; extensive } \\
\text { production of sea ice on Antarctica; devel- } \\
\text { opment of present thermohaline deep-water } \\
\text { circulation; abrupt increase in depth of } \\
\text { CCD world wide (except in Angola Basin) } \\
\text { (Heath, 1969; van Andel and Moore, 1974; } \\
\text { Berger,1981; Kennett et al., 1974; van } \\
\text { Andel et al., 1977) }\end{array}$ \\
\hline $\begin{array}{l}\text { early middle Eo- } \\
\text { cene (ca. } 49 \\
\text { m.y.) }\end{array}$ & $\begin{array}{l}\text { Sharp drop in accumulation of } \mathrm{CaCO}_{3} \text { from } \\
\text { maximum accumulation in the white-fan } \\
\text { facies, to near zero }\end{array}$ & Shoaling of the CCD \\
\hline $\begin{array}{l}\text { early Eocene to } \\
\text { Maestrichtian } \\
\text { (50-70 m.y.) }\end{array}$ & $\begin{array}{l}\text { period of maximum accumulation of } \mathrm{CaCO}_{3} \\
\text { (white-fan facies) }\end{array}$ & Maximum depth of the CCD \\
\hline
\end{tabular}

middle Eocene to middle Oligocene section (Fig. 2 and 12). The nonturbidite red and green clay that did accumulate (Unit 3) is very uniform in composition in marked contrast to the highly variable lithologies of the underlying turbidite units. The cessation of carbonate accumulation at the end of the Eocene at Site 530 is very abrupt. Conditions must have changed suddenly from a period of maximum accumulation of carbonate to a period during which no carbonate accumulated. The Eocene and Oligocene was also a period of reduced rate of sedimentation at Site 530 (Fig. 5.). The lack of carbonate accumulation in the southern Angola Basin during this time probably was caused both by a shoaling of the CCD and by a rising of global sea level (Fig. 2). As a result, less carbonate was supplied by turbidity currents from carbonate platforms on Walvis Ridge and the African continental margin, and less was preserved because of the shallower CCD (Stow, this volume).

The Eocene/Oligocene boundary at Site 364 on the eastern margin of the Angola Basin also is marked by an abrupt cessation of carbonate accumulation and an apparent middle Eocene to middle Oligocene unconformity (Bolli, Ryan, et al., 1978; Fig. 12). The sediment that did accumulate at Site 364 consists of pelagic brown clay of middle Oligocene to possibly early Miocene age. This apparent sudden shoaling of the CCD during the Eocene in the Angola Basin was not expected because everywhere else in the Atlantic and in the Pacific the CCD became much deeper at about the Eocene/ Oligocene boundary (ca. 38 m.y. ago; Fig. 13; Heath, 1969; van Andel and Moore, 1974; van Andel et al., 1977; Berger, 1981).
The Eocene-Oligocene unconformity (or compressed section) was expected, however, because unconformities at the Eocene/Oligocene boundary have been recognized at many sites worldwide (Kennett et al., 1974). This unconformity apparently was due to the combination of (1) extensive development of shelf ice on Antarctica and concomitant generation and vigorous flow of cold bottom-water leading to development of modern thermohaline circulation (Douglas and Savin, 1975; Savin et al., 1975; Kennett et al., 1974; Shackleton and Kennett, 1974a; Boersma and Shackleton, 1977a and 1977b; McCoy and Zimmerman, 1977; van Andel et al., 1977); (2) increased north-south temperature gradients caused by major cooling at high latitudes; (3) stronger circum-polar flow resulting from the complete separation of Antarctica and Australia by later Eocene (Kennett et al., 1974); and (4) a sharp drop in sea level during the Eocene (Fig. 2). In view of these circulation and sealevel patterns in the late Eocene and Oligocene, the sharp decrease in carbonate accumulation in the Angola Basin is what one intuitively would expect in response to an increased flow of cold, $\mathrm{CO}_{2}$-rich corrosive bottom waters which would dissolve more carbonate. If the response of carbonate accumulation to bottom-water flow in the Angola Basin at the end of the Eocene is "normal," then the "abnormal" decrease in the CCD in the other ocean basins, including those of the western South Atlantic, during the late Eocene to early Oligocene, remains to be explained. The sharp drop in sea level during the Oligocene proposed by Vail et al. (1977) would have greatly decreased the area of shelf seas available for carbonate sedimentation and caused the global 


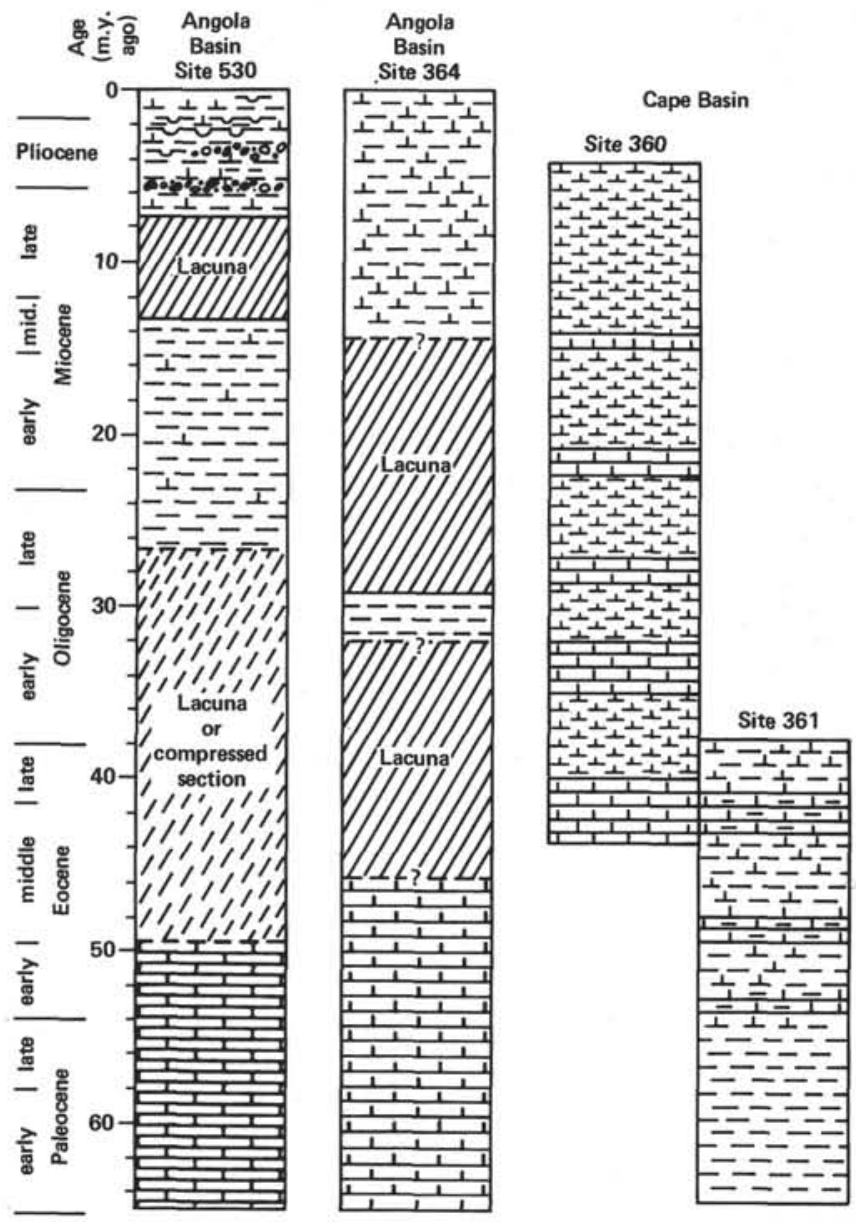

Figure 12. Schematic diagrams showing lithology and lacunas for DSDP Sites 530 (southern Angola Basin), 364 (eastern Angola Basin), and 361 and 360 (Cape Basin).

carbonate balance to be maintained by shifting carbonate sedimentation almost exclusively to the deep sea as suggested by Hay and Southam (1977) and documented by Worsley and Davies (1979). The differences between the depth of the CCD in the Angola Basin and in the rest of the world ocean must be related to the restriction of the Angola Basin with respect to circulation of bottom waters formed in other parts of the world. It might be expected that the greater restriction of the Angola Basin to bottom-water flow should cause the CCD to be deeper in the Angola Basin than in other basins in the South Atlantic just as it is today, but evidently this was not the case. Perhaps the answer lies in greater production of carbonate in other basins during the middle Eocene to middle Miocene related to local conditions of productivity. For example, the much greater depth of the CCD in the Equatorial Pacific throughout the Cenozoic (Fig. 13) results from the greater rate of fixation of carbonate by calcareous plankton in the surface waters of that area (Berger, 1973; Berger and Winterer, 1974; van Andel et al., 1977). Average sedimentation rates for carbonate in the Pacific were double those in the Atlantic during the Oligocene, whereas the situation is reversed at present (Southam and Hay, 1982). The causes

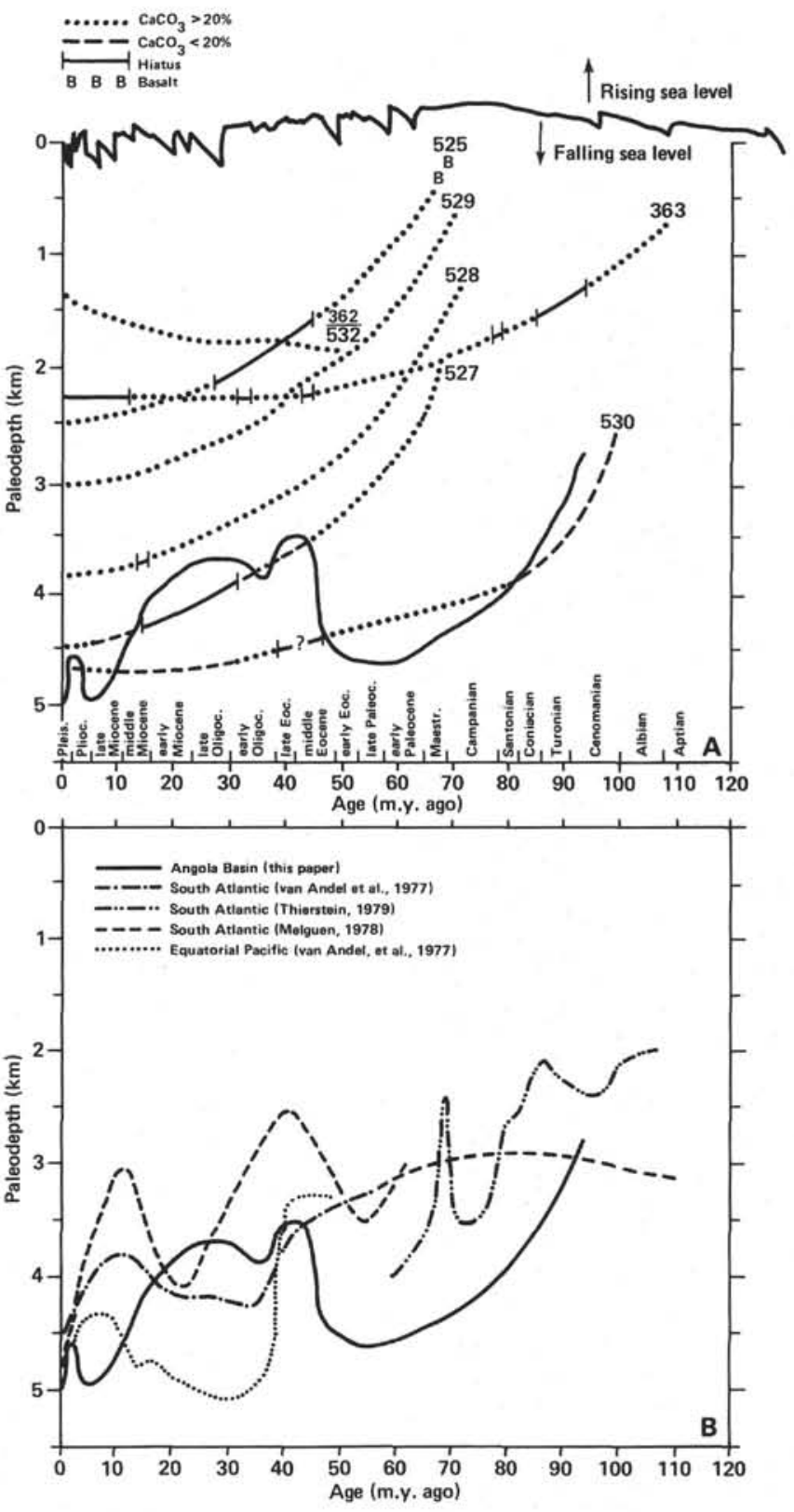

Figure 13. A. Age versus paleodepth backtracking curves for DSDP Sites $362 / 532,363,525,527,528,529$, and 530 on Walvis Ridge and adjacent Angola Basin. Equation for and discussion of method of backtracking is in Site 530 chapter (this volume). Periods of time represented by hiatuses or by sediments containing $>20 \% \mathrm{Ca}$ $\mathrm{CO}_{3}$ and $<20 \% \mathrm{CaCO}_{3}$ are shown on the backtracking curves. Data are from Bolli, Ryan, et al. (1978), Moore, Rabinowitz, et al. (in press), and Site 530 chapter (this volume). The solid curve through data for Sites 527 and 530 represents an approximate curve of the depth of the CCD in the Angola Basin through time as determined by a sediment composition of $20 \% \mathrm{CaCO}_{3}$. The curve across the top of the diagram is a curve of relative sea level change from Vail et al. (1977). B. Curves of paleodepth of the CCD versus age for the South Atlantic as reported by various authors. A curve of the CCD for the equatorial Pacific is provided for comparison.

of this partitioning of carbonate between ocean basins are not yet fully known.

During the middle Miocene there was a major increase in sea level and the resulting transgression appar- 
ently caused a marked increase in the mass accumulation rate of sediment (Fig. 2), which remained high for the remainder of the Cenozoic. This may have signaled the beginning of the brown-fan facies of Stow (this volume) characterized by an increase in kaolinite, chlorite, and quartz (Fig. 2).

By the end of the Miocene, an ice sheet had developed on Antarctica that was much thicker than at present (Frakes and Kemp, 1973; Shackleton and Kennett, 1974a), and this had far-reaching effects on global climates and oceanography. The accumulation of this ice sheet resulted in the formation of AABW which may have been even more vigorous than at present. The vigorous flow of bottom water may have been responsible for erosion on the Falkland Plateau (Barker, Dalziel, et al., 1977), the formation of the middle to late Miocene (ca. 13-7 m.y.) unconformity at Site 530 (Fig. 12), and maximum accumulation of debris-flow deposits in the brown-fan facies at Site 530 (Figs. 2, 3). Like the Eocene-Oligocene unconformity, the Miocene unconformity corresponds to a drop in global sea level (Fig. 2) caused by the buildup of ice on Antarctica. The vigorous flow of AABW also resulted in a global shoaling of the CCD (Fig. 13B), but again, the Angola Basin was out of phase with the rest of the world ocean, probably because of its greater restriction to bottom-water flow. Following the middle to late Miocene unconformity, the CCD in the Angola Basin dropped so that concentrations of $\mathrm{CaCO}_{3}$ at Site 530 increased from near zero in the middle Miocene to about $75 \%$ in late Miocene sediments (Fig. 2). Deposition of $\mathrm{CaCO}_{3}$ also resumed at Site 364 in the eastern Angola Basin following the Oligocene-Miocene unconformity (Fig. 12).

The late Miocene also marks the beginning of the Benguela Current and associated upwelling off the coast of southwest Africa (Siesser, 1980). The development of Benguela upwelling is discussed in greater detail later in the section on Site 532. Benguela upwelling reached a maximum at both Sites 530 and 532 during the late Pliocene to early Pleistocene, and then decreased to the present. Pollen data by van Zinderen Bakker (this volume) indicate that the coastal regions of Namibia became very arid during the Pliocene and remain that way through the present. Any moisture along these coastal regions is derived from coastal fog generated by the cold waters of the Benguela Current. In Hole 530B, the peak of Benguela upwelling in the early Pleistocene is indicated by marked increases in the concentrations of biosiliceous debris (mostly diatoms) and organic carbon, and a marked decrease in $\mathrm{CaCO}_{3}$ in Subunit $1 \mathrm{~b}$ (Fig. 3). This relationship may be the result of dilution of $\mathrm{CaCO}_{3}$ by diatom debris or of a marked decrease in the CCD in the early Pleistocene. The fact that the percentage of nonbiogenic material (clay) is not affected by the increase in diatom debris, and the well-known shallowing of the CCD under areas of high organic productivity (e.g., Bramlette, 1965; Berger and Roth, 1975; van Andel et al., 1975), suggest that the CCD did become shallower.

\section{SITE 531}

Site 531 is located on Walvis Ridge southeast of Site 530 in a water depth of $1267 \mathrm{~m}$ (Fig. 1). Two attempts to spud in at this site failed because the bottom was too hard. Two cores were attempted, and both recovered a small amount of Pleistocene to Holocene foraminifer sand. However, the second core (from Hole 531A) contained a single small rock fragment about $1 \mathrm{~cm}$ across. This fragment consisted dominantly of rounded to subrounded coarse-sand sized clasts of volcanic rocks, red coralline algae, mollusks, and possibly coral cemented by calcite. The red coralline algae are Archaeolithothamnium (J. L. Wray, pers. comm., 1981), which has a range of Late Jurassic to present and therefore cannot be used to date the rock. The virtual absence of young soft sediment on Walvis Ridge at Site 531 suggests that at least the edges of the ridge have been swept clean by currents. The subsidence history of Walvis Ridge suggests that the area of Site 531 subsided below sea level during the Early Cretaceous (Goslin and Sibuet, 1975; Sibuet et al., this volume). If the shallow-water carbonate material recovered at Site 531 formed during the Cretaceous, then these materials extend the maximum southern limit of southern hemisphere Cretaceous reefal carbonates plotted by Habicht (1979) by about 5. However, Archaeolithothamnium may not have been restricted to tropical and subtropical climates.

\section{SITE 532}

\section{Lithologic Units}

The sediments recovered at Site 532 essentially can be defined in terms of a three-component system of calcareous microfossils, siliceous microfossils, and nonbiogenic material (Fig. 14). The nonbiogenic material is mostly clay, the siliceous microfossils are mostly diatoms, and the calcareous microfossils are mostly nannofossils; foraminifers are quantitatively important only in the upper $50 \mathrm{~m}$ of section. Consequently, variations in sediment composition consist mainly of variations in the relative abundances of clay, diatoms, and nannofossils. Based on the relative proportions of these three components, the sediment section recovered at Site 532 was divided into three subunits (Fig. 14). Subunits 1a and 1c consist predominantly of clay and calcareous microfossils and are separated by Subunit $1 \mathrm{~b}$, which is rich in siliceous microfossils, mostly diatoms. Nannofossils are the dominant biogenic component of Subunit 1c (114 to $291 \mathrm{~m})$ and compose 20 to $50 \%$ of the sediment. Diatoms, radiolarians, sponge spicules, and foraminifers amount to only a few percent each in most samples that were examined (Site 532, this volume).

Diatoms make up 20 to $50 \%$ of the sediment in Subunit $1 \mathrm{~b}$. Other siliceous-biogenic debris consists of a few percent each of radiolarians, silicoflagellates, and sponge spicules. Nannofossils and nonbiogenic material (mostly silt and clay; Fig. 14) each compose an average of about $30 \%$ of the sediment in Subunit 1b so that the sediments of this subunit are composed of more or less equal mixtures of diatoms, nannofossils, and nonbiogenic material. The high abundances of diatoms in Subunit $1 \mathrm{~b}$ have resulted in relatively high porosities and water content of the sediments (Fig. 14; Bennett et al., and Boyce, both this volume).

The relative abundances of both nonbiogenic and siliceous-biogenic components decreases upward within 
Subunit 1a. This is the only part of the section recovered at Site 532 where foraminifers are a significant component in the sediment, increasing from less than $10 \%$ at the base of the subunit to more than $50 \%$ at the top. Foraminifers replace nannofossils as the dominant calcareous microfossils in the top $10 \mathrm{~m}$ of the section. The net result is that the content of biogenic silica decreases to zero at the top of the section, and the content of Ca$\mathrm{CO}_{3}$, increases from about $30 \%$ to about $60 \%$ (Fig. 14). Because of the abundance of foraminifers, this is also the only part of the section at Site $\mathbf{5 3 2}$ that contains a significant sand-size component of the bulk sediment (Fig. 14; Bennett et al., this volume). The results of size analyses from Holes 532 and 532B, plotted in Figure 14, were obtained from the size-analysis laboratory at DSDP (Bode, this volume), and show only an increase of a few percent sand in the upper $50 \mathrm{~m}$. However, results of size analyses from Hole 532A obtained by the physical properties consortium (Bennett et al., this volume) show that the upper $50 \mathrm{~m}$ of section contains up to $30 \%$ sand. Because of the high abundance of foraminifers in the upper part of the section, we conclude that the DSDP size analyses (Fig. 14) underestimated the percentage of sand in the upper part of the section in Hole 532.

Down-hole variation in abundance of calcareous microfossils is indicated in Figure 14 by two independent measurements. The first is the percentage of total calcareous-biogenic components from shipboard smearslide estimates. The second is the measured percentage of $\mathrm{CaCO}_{3}$ from shipboard and shore studies (Gardner et al., this volume). Downhole variation in abundance of siliceous-biogenic components also is indicated in Figure 14 by two independent methods. The first is the percentage of total siliceous-biogenic components from shipboard smear-slide estimates. The second is the percentage of biogenic $\mathrm{SiO}_{2}$ calculated from measured concentrations of total $\mathrm{SiO}_{2}$ normalized to the nonbiogenic $\mathrm{SiO}_{2}: \mathrm{Al}_{2} \mathrm{O}_{3}$ ratio (Dean and Parduhn, this volume). For both calcareous and siliceous components, the first estimate of abundance (smear-slide estimate) is a volume estimate that is semiquantitative at best. The second estimate of abundance (chemical analysis) is a gravimetric measurement and is more accurate than the smear-slide estimates, particularly if the estimates are used for calculation of mass accumulation rates.

In addition to the calcareous-biogenic, siliceous-biogenic, and nonbiogenic components that compose the bulk of the sediment recovered at Site 532, organic carbon is a qualitatively important fourth component which usually has a concentration of several percent to as much as $8 \%$ (Fig. 14). The average concentration of organic carbon increases from less than $2 \%$ at the base of the section to about $4 \%$ in the surface sediment (Fig. 14). The amount of organic carbon is low relative to the amounts of the three main components, but it is important in helping to understand the history of organic productivity at Site 532. This organic carbon is dominantly of marine origin but with a significant component of terrestrial organic matter (Meyers, Brassell, and Huc, and Rullkötter et al., both this volume). Rullkötter et al. estimated that more than $75 \%$ of the organic matter is composed of degraded amorphous bituminite.

The high concentrations of organic carbon and high sedimentation rate of sediments at Site 532 (Figs. 14 and 15) also are reflected in the alkalinity of interstitial waters (Site 532, this volume). Alkalinity increases sharply from about $2 \mathrm{meq} / 1$ at the sediment-water interface to about $20 \mathrm{meq} / 1$ at $80 \mathrm{~m}$ sub-bottom. Such a sharp increase in alkalinity suggests that sulfate reduction and methanogenesis occur below about $80 \mathrm{~m}$, and, in fact, methane was first detected in Core 532-29 (123 m subbottom) and was present in all subsequent cores (Site 532, this volume). Parts of most cores below about 113 $\mathrm{m}$ sub-bottom also were severely gas cracked. Sulfate reduction and methane generation usually are accompanied by release of phosphate in the sediment column, but bulk-sediment analyses of phosphorous by Dean and Parduhn (this volume) did not show any significant variation throughout the section.

\section{Cyclic Sedimentation on Walvis Ridge}

Throughout all of the lithologic variations described above, the most notable characteristic, which persists through all subunits, is the cyclic alternation of dark and light sediment layers. The dark-light couplets usually are between 1 and $3 \mathrm{~m}$ thick, with gradational contacts over 10 to $20 \mathrm{~cm}$ caused by extensive bioturbation of both light and dark materials. Average periodicities of the dark-light cycles are 55, 58, and $30 \mathrm{k} . \mathrm{y}$. for the Quaternary, upper Pliocene, and lower Pliocene parts of the section, respectively (Gardner et al., this volume).

The lighter parts of most cycles contain more $\mathrm{CaCO}_{3}$ (Fig. 16), and the darker parts contain more clay. The darker parts of the cycles usually also contain more organic carbon, but commonly there are high concentrations of organic carbon that do not appear to correspond to color changes (see Fig. 16). The average concentrations of $\mathrm{CaCO}_{3}$ and organic carbon in 85 light-colored beds analyzed by Meyers, Brassell, and Huc (this volume) are $51.5 \%$ and $2.07 \%$, respectively. The average concentrations of $\mathrm{CaCO}_{3}$ and organic carbon in 65 dark-colored beds analyzed by Meyers, Brassell, and Huc are $31.8 \%$ and $3.71 \%$, respectively. Smearslide estimates of biogenic components show that variations in abundances of siliceous and calcareous microfossils do not appear to be systematically related to color variations (Site 532 and Gardner et al., both this volume). Sancetta (this volume) examined the abundance and preservation of diatoms in two cycles. She found that usually diatoms are rare and poorly preserved in both light and dark parts of the cycles, and most abundant and best preserved in intermediate lithologies. Sancetta also found that the diatom assemblage in the cycles was composed of the more pelagic forms, which implies that changes in abundance and preservation of diatoms within the cycles were caused by changes in bottom-water conditions rather than changes in surface-water productivity.

Detailed analyses of $\mathrm{CaCO}_{3}$ and organic carbon by Gardner et al. (this volume) show marked cyclic fluctuations (Fig. 14) that are related to the color cycles but not 

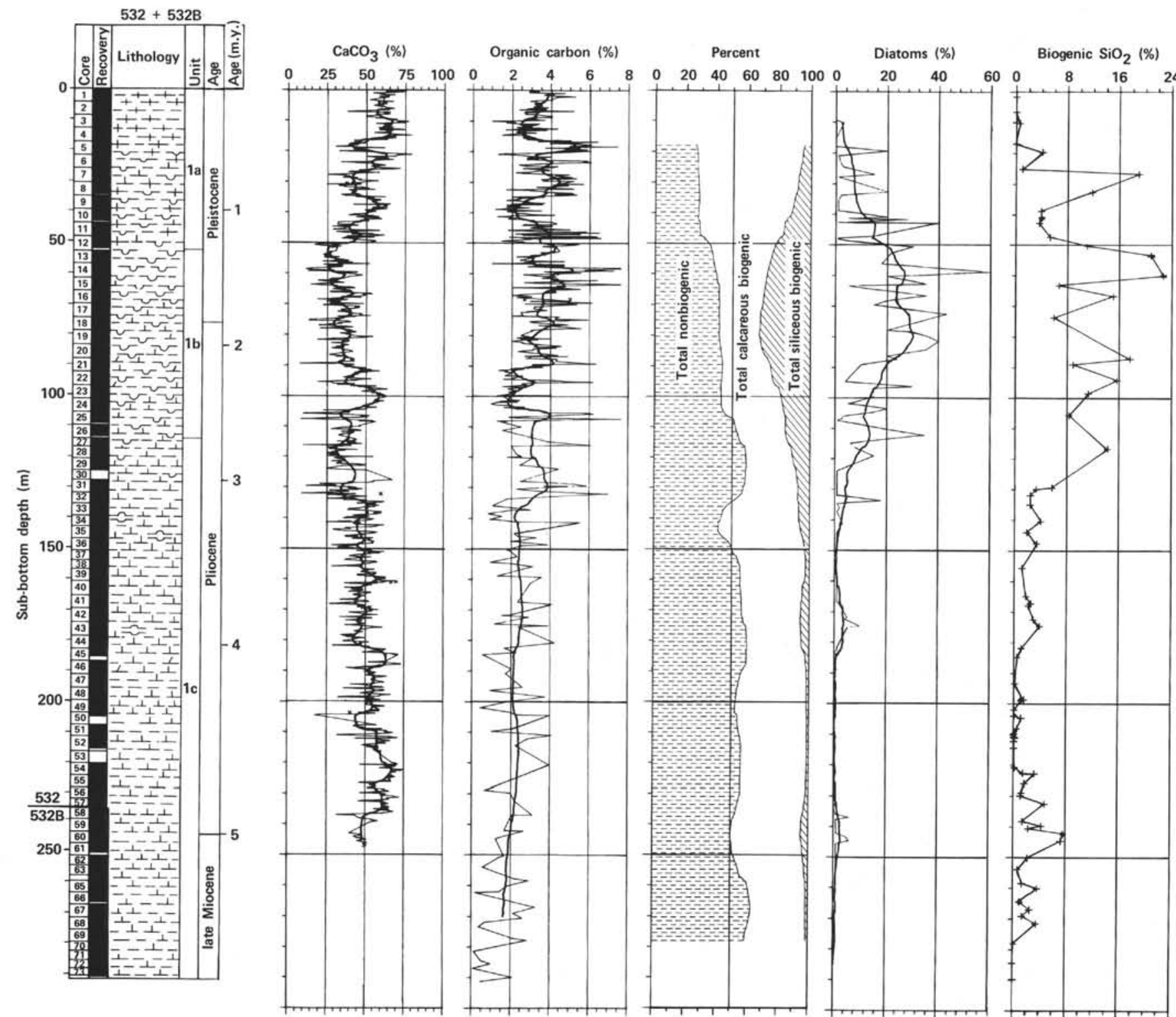

Figure 14. Site summary chart, Site 532, Walvis Ridge. The data for the summary are compiled from the following sources: percent $\mathrm{CaCO}_{3}$ and percent organic carbon from Gardner et al. (this volume); percent total nonbiogenic components, percent total siliceous biogenic components, percent total calcareous biogenic components, and percent diatoms from smear-slide estimates in Site 532 chapter (this volume); percent biogenic $\mathrm{SiO}_{2}$ from Dean and Parduhn (this volume), percent sand-silt-clay from Bode (this volume). Mass accumulation rates of bulk sediment, nonbiogenic components, $\mathrm{CaCO}_{3}$, biogenic $\mathrm{SiO}_{2}$, and organic carbon were computed from data in Gardner et al., Dean and Parduhn, Steinmetz and Stradner, and Site 532 chapter (all this volume); Rock-Eval S-2, wet-bulk density, porosity, water content, compressional sound velocity, and acoustic impedance from Site 532 chapter (this volume).

in detail because, as explained above, changes in abundance of organic carbon do not always correspond to color changes. The periodicities of $\mathrm{CaCO}_{3}$ cycles range from 26 k.y. to 49 k.y., and average about 36 k.y. for the past $5 \mathrm{~m} . \mathrm{y}$. The periodicities of organic carbon cycles range from about 28 k.y. to 36 k.y., and average about 34 k.y. for the past 2.5 m.y. Detailed profiles of both $\mathrm{CaCO}_{3}$ and organic carbon (Fig. 14) also show longerperiod cycles with average periodicities of about 130 k.y. The periodicities of the color and $\mathrm{CaCO}_{3}$ cycles, and the systematic changes in periodicities with time, are similar to those of carbonate cycles from the northeastern Atlantic, Caribbean, and eastern equatorial $\mathrm{Pa}$ cific. Gardner et al. (this volume) concluded that the cycles at Site 532 were not caused by carbonate dissolution or by purely local variations in productivity associated with the development of the Benguela upwelling system, but are a manifestation of cyclic changes in global climate. They interpreted the carbonate and color cycles in terms of fluctuations of influx of terrigenous detrital clastic material. The pulsing of terrigenous clastics was caused by changes in eustatic sea level, which, in turn, 


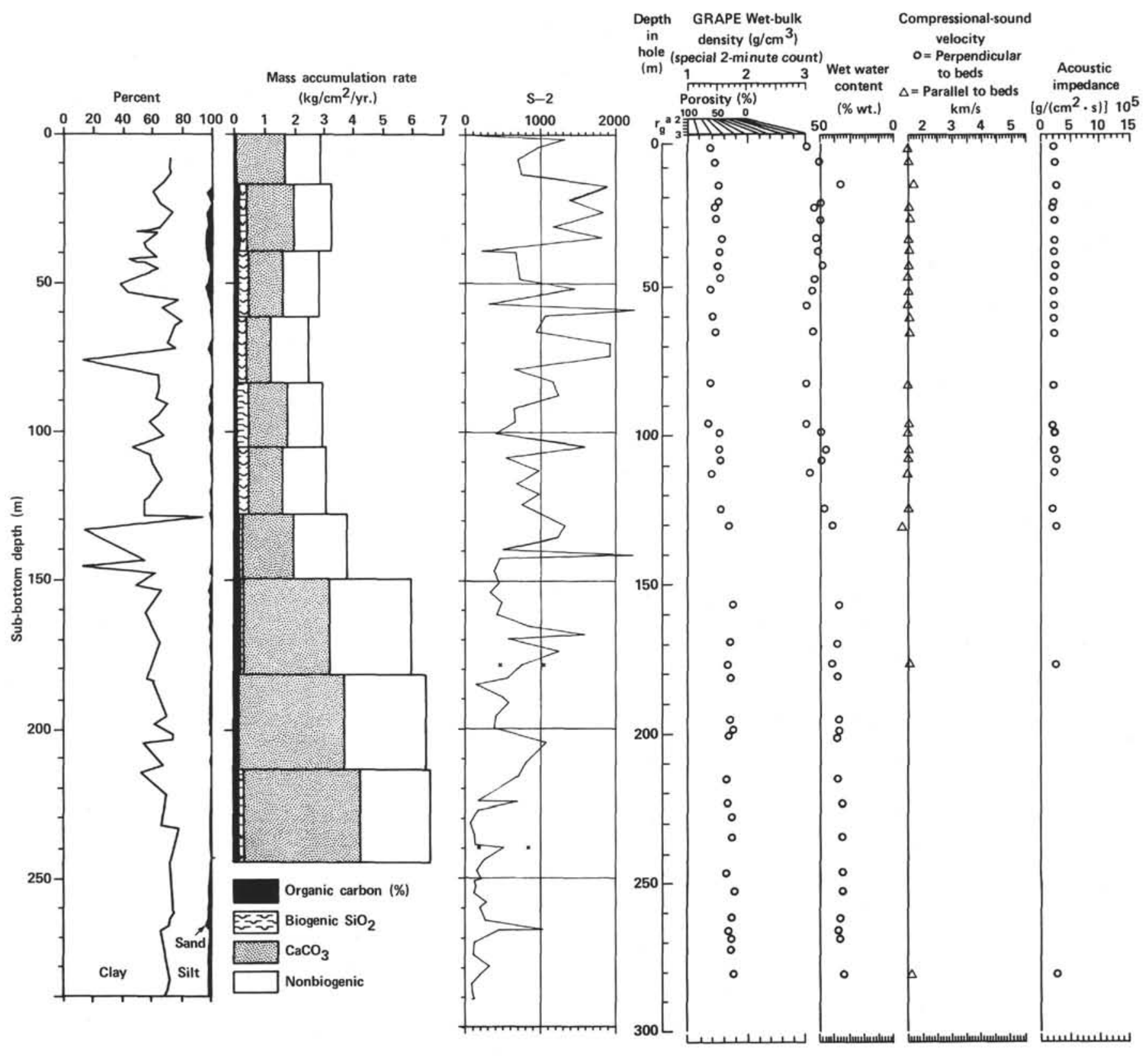

Figure 14. (Continued).

were caused by changes in polar ice volume. Sediment that was stored on submerged shelves during eustatic high-stands was shed and deposited offshore during eustatic low-stands, resulting in an increase in the flux of terrigenous material to dilute pelagic biogenic carbonate and silica.

\section{History of Benguela Upwelling}

Total sediment accumulation rates for DSDP Site 362 near Site 532 on Walvis Ridge reach a maximum in the upper Miocene section (Bolli, Ryan, et al., 1978; Siesser, 1980). Based on this maximum sediment accumulation rate and the fact that diatoms begin to occur in sediments of early late Miocene age, Siesser (1980) concluded that the Benguela upwelling system began at this time (ca. 10 m.y. ago). The late Miocene to early Plio- cene also was a time of major increases in upwelling and organic productivity at the Antarctic convergence (Kennett et al., 1974) due to increased bottom-water circulation related to the development of an Antarctic ice sheet that was much thicker than at present (Shackleton and Kennett, 1974a). We did not recover sediments old enough at Site 532 to determine whether upwelling did indeed begin ca. 10 m.y. ago, but we do have abundant data that define changes in Benguela upwelling during the past 6 m.y. We used the relative abundance of diatom remains as the main indicator of upwelling intensity because diatoms are the dominant biogenic component in most mid-latitude, open-ocean upwelling areas (Diester-Haass and Schrader, 1979; Schuette and Schrader, 1981). Examination of smear slides showed that diatoms were the dominant siliceous biogenic com- 


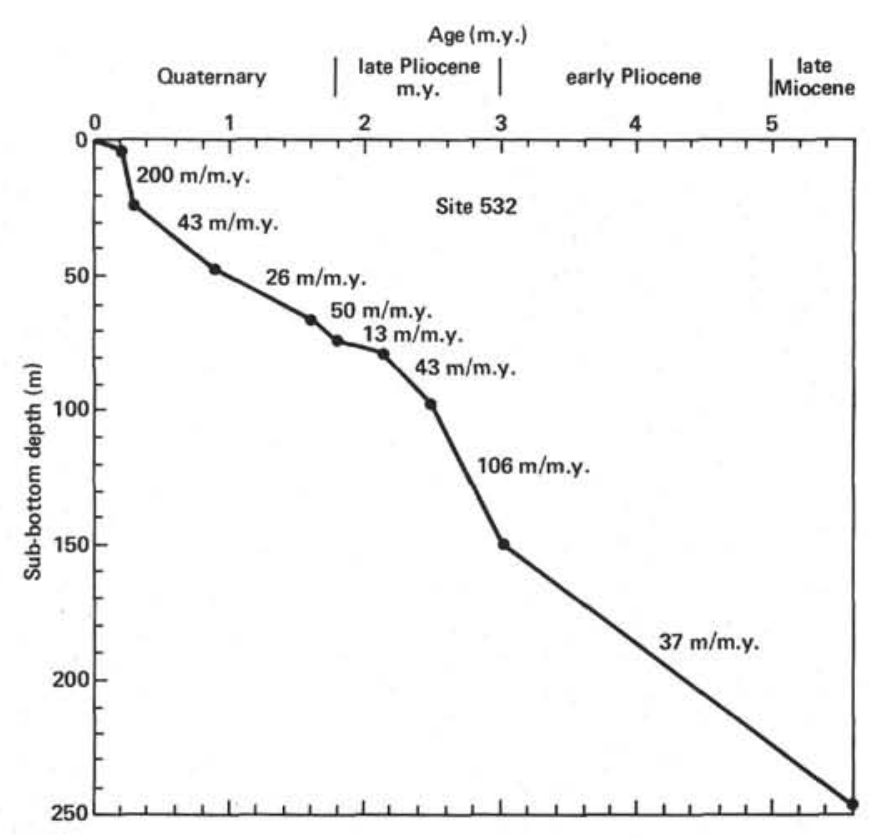

Figure 15. Sedimentation-rate curve for Site 532.

ponents in the sediments and commonly compose about one-third of the sediment by volumetric smear-slide estimate in the upper Pliocene to lower Pleistocene parts of the section recovered (Site 532, this volume; Fig. 14). The diatom flora is completely dominated by forms that are adapted to upwelling conditions (Sancetta, this volume). Smear-slide estimates are volumetric and tend to overestimate the highly porous siliceous biogenic components, such as diatoms. Gravimetric estimates of biogenic $\mathrm{SiO}_{2}$, derived mainly from diatoms, obtained by analyses of $\mathrm{SiO}_{2}$ and $\mathrm{Al}_{2} \mathrm{O}_{3}$ (Dean and Parduhn, this volume), show that biogenic $\mathrm{SiO}_{2}$ reaches a maximum of 10 to $15 \%$ in the sediments of late Pliocene and early Pleistocene age. Gardner et al. (this volume) calculated that mass accumulation rates of biogenic $\mathrm{SiO}_{2}$ increased about fourfold in this same interval (Fig. 14).

The increase in biogenic $\mathrm{SiO}_{2}$ is particularly evident in a plot of biogenic $\mathrm{SiO}_{2}, \mathrm{CaCO}_{3}$, and organic carbon for 0.5-m.y. intervals (Fig. 17). This plot shows that biogenic $\mathrm{SiO}_{2}$, relative to the other two biogenic components, increased markedly about 3 m.y. ago (between points $d$ and e in Fig. 17), remained relatively high between 3 and $1 \mathrm{~m}$.y. ago (points e-h), and then decreased rapidly thereafter.

The evidence from biosiliceous material at Site 530 in the Angola Basin is even more striking, although the section there is complicated by hiatuses, turbidites, and debris-flow deposits (Fig. 3). Concentrations of biogenic $\mathrm{SiO}_{2}$ are over $30 \%$ in parts of the lower Pleistocene section in Hole 532B (Fig. 3), and the maximum mass accumulation rate of biogenic $\mathrm{SiO}_{2}$ is more than five times higher than the maximum mass accumulation rate of biogenic $\mathrm{SiO}_{2}$ at Site 532. The most common diatoms in the debris-flow deposits at Site 530 are all displaced from shelf depths (Sancetta, this volume).

In general, the amount of organic carbon in the sediments reflects the inferred period of higher productivity

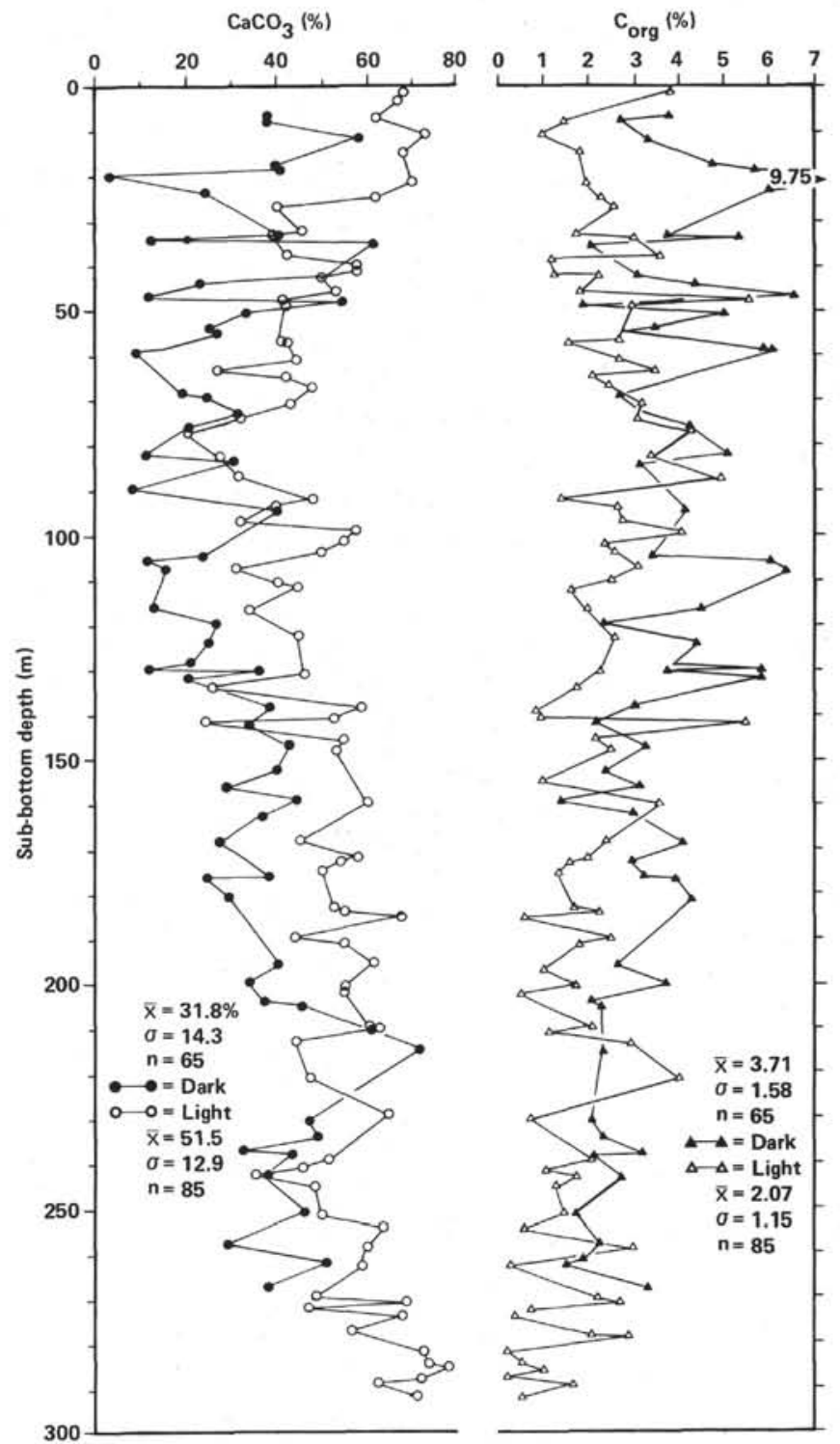

Figure 16. Plots of percent $\mathrm{CaCO}_{3}$ and percent organic carbon $\left(\mathrm{C}_{\text {org }}\right)$ in samples of 85 light-colored beds and 65 dark-colored beds from Site 532. Data are from Meyers, Brassell, and Huc (this volume).

during the late Pliocene and early Pleistocene (Figs. 3 and 14). Most of the variability in the organic-carbon data, however, results from the higher frequency (shorter period) cycles discussed by Gardner et al. (this volume). If the interpretations by Gardner et al. about the relationships among polar ice volume, sea level, and influx of terrigenous clastics are correct, then periods of greater clastic influx (dilution of $\mathrm{CaCO}_{3}$, greater ice volume, decrease in sea level) would also tend to be periods of more vigorous circulation, upwelling, and productivity. This would explain the usual coincidence of high concentrations of marine organic carbon in dark, clayrich beds, and the general inverse relationship between organic carbon and $\mathrm{CaCO}_{3}$. To the extent that upwelling was affected by other variables, particularly local conditions of circulation along the African continental margin and Walvis Ridge, there would have been other periods of increased upwelling and productivity that 


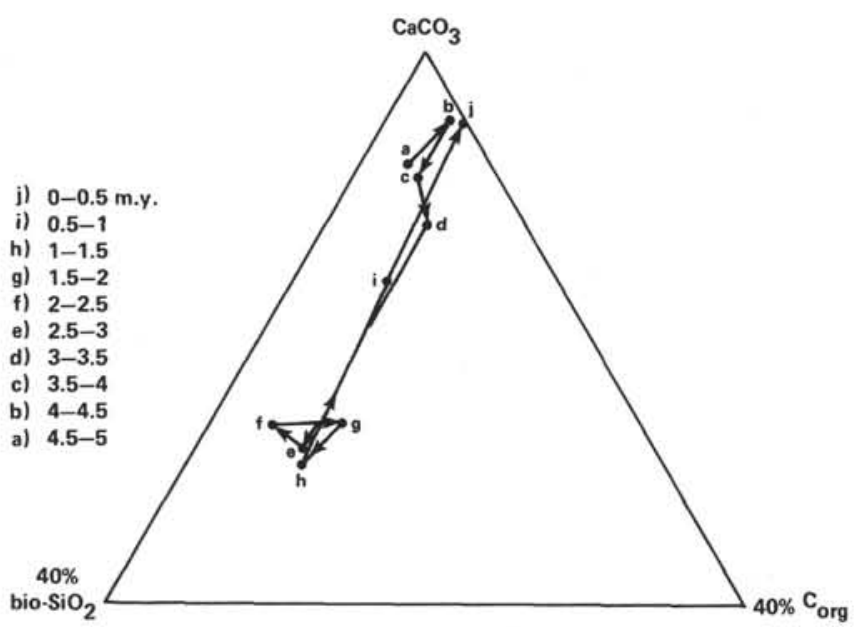

Figure 17. Triangular diagram showing variations in the relative concentrations of $\mathrm{CaCO}_{3}$, biogenic $\mathrm{SiO}_{2}$, and organic carbon at 0.5m.y. intervals at Site 532 .

would not affect the influx of terrigenous clastics. This would explain the additional organic-carbon maxima that are not related to the color cycles, and shorter periodicities of the organic-carbon cycles.

Assuming that the relative amount of biosiliceous material in the sediments can be used as a relative measure of Benguela upwelling, then upwelling at Site 532 began to increase about 3 m.y. ago, reached a peak during the later Pliocene and early Pleistocene, and has been declining ever since. The surprising result of both smear-slide and chemical estimates of biogenic silica is that the top of the section recovered at Site 532 does not contain any biogenic silica. Mass accumulation rates for the post-upwelling period ( $<1.0$ m.y. ago) reflect a $99 \%$ reduction in biogenic silica relative to values during the upwelling period. The flux of $\mathrm{CaCO}_{3}$, on the other hand, increased by $28 \%$ during the post-upwelling period. The post-upwelling period is somewhat complicated by apparent winnowing as indicated by the marked increase in foraminifers in the top $50 \mathrm{~m}$ (Site 532 chapter and Gardner et al., both this volume). The siliceous biogenic material may have been removed by winnowing, or, more likely, the decrease in siliceous biogenic material reflects a change in location and intensity of the main core of coastal upwelling. Similar abrupt changes in texture and diatom concentrations also were found by Diester-Haass (1978) in a core of Holocene sediments on the continental shelf of southwest Africa. The upper $120 \mathrm{~cm}$ of this core consisted of coarse skeletal sand. Between 120 and $200 \mathrm{~cm}$ the sediment consisted of black mud containing small $(<40 \mu \mathrm{m})$ diatoms and 4 to $8 \%$ organic carbon. The main section of upwelling-influenced sediment was between 200 and 290 m, which consisted of finely laminated, olive-green diatom ooze in which diatoms were the dominant components in all size fractions. This upwelling facies also contained 6 to $10 \%$ organic carbon and abundant fish debris. The abrupt facies change indicate that sedimentation conditions on the continental shelf of southwest Africa were highly variable, but Diester-Haass (1978) was not able to determine if these facies changes were due to changes in the position of upwelling water masses or to bottom currents. Certainly the coastal regions of southwest Africa today are characterized by high productivity of siliceous organisms (Schuette and Schrader, 1981), and this suggests that the lack of siliceous organisms in the upper part of the section at Site 532 cannot be used as evidence that productivity was not occurring elsewhere off southwest Africa. For example, Schutte and Schrader (1981) found that diatoms in surface sediments off southwest Africa are extremely abundant in nearshore areas of coastal upwelling, tend to occur in patches or belts, and are absent or in low abundance in adjacent offshore areas.

Similarly, the lack of siliceous biogenic material in the lower part of the section of Site 532 does not mean that intense upwelling associated with the Benguela upwelling system did not occur elsewhere during the late Miocene and early Pliocene as suggested by the data from Site 362 (Diester-Haass and Schrader, 1979; Siesser, 1980). In fact, the diatom data from the upper part of the section at Site 362 (Diester-Haass and Schrader, 1979) complement the data from Site 532. Although diatoms first appear in the upper Miocene part of the section at Site 362, they decrease in abundance and degree of preservation near the Miocene/Pliocene boundary, and are in maximum abundance and best preserved in the upper Pliocene to lower Pleistocene part of the section. Diester-Haass and Schrader point out that the drastic decrease in diatom abundance and preservation in the latest Miocene coincides with the Messinian "salinity crisis" (Hsü et al., 1973) and the maximum seaward extension of glaciation in Antarctica (Kennett et al., 1974; Hayes et al., 1975). Another possible explanation for the changes in diatom abundance may be changes in sea level. The periods of maximum diatom abundance in the early late Miocene and in the late Pliocene to early Pleistocene correspond to periods of marked sea level regressions (Fig. 2) in response to the extensive glaciation of Antarctica (middle Miocene; Shackleton and Kennett, 1974a; Hayes et al., 1975), and initiation of glaciation in the northern hemisphere (Pliocene-Pleistocene; Shackleton and Kennett, 1974b). The period of low diatom abundance and poor preservation in the latest Miocene to early Pliocene corresponds to a period of marked sea level regression (Fig. 2). Falling sea level simply may have brought the nearshore areas of high productivity closer to Site $\mathbf{5 3 2}$.

\section{ACOUSTIC STRATIGRAPHY, ANGOLA BASIN, AND ADJACENT WALVIS RIDGE}

Based on multichannel seismic surveys in the area of eastern Walvis Ridge and the Cape and Angola basins, four acoustic units have been defined and correlated with stratigraphic sections recovered at DSDP Sites 530, 531, 362, 532, and 363 (Sibuet et al., this volume).

In the Angola Basin, acoustic Unit 1 overlies the acoustic basement of oceanic origin and fills in the depressions (Fig. 18). It wedges out to the west in the vicinity of Site 530. On the eastern Walvis Ridge, acoustic Unit 1 rests on dipping internal basement reflectors of structural provinces 1 and 2 of Sibuet et al. (this vol- 

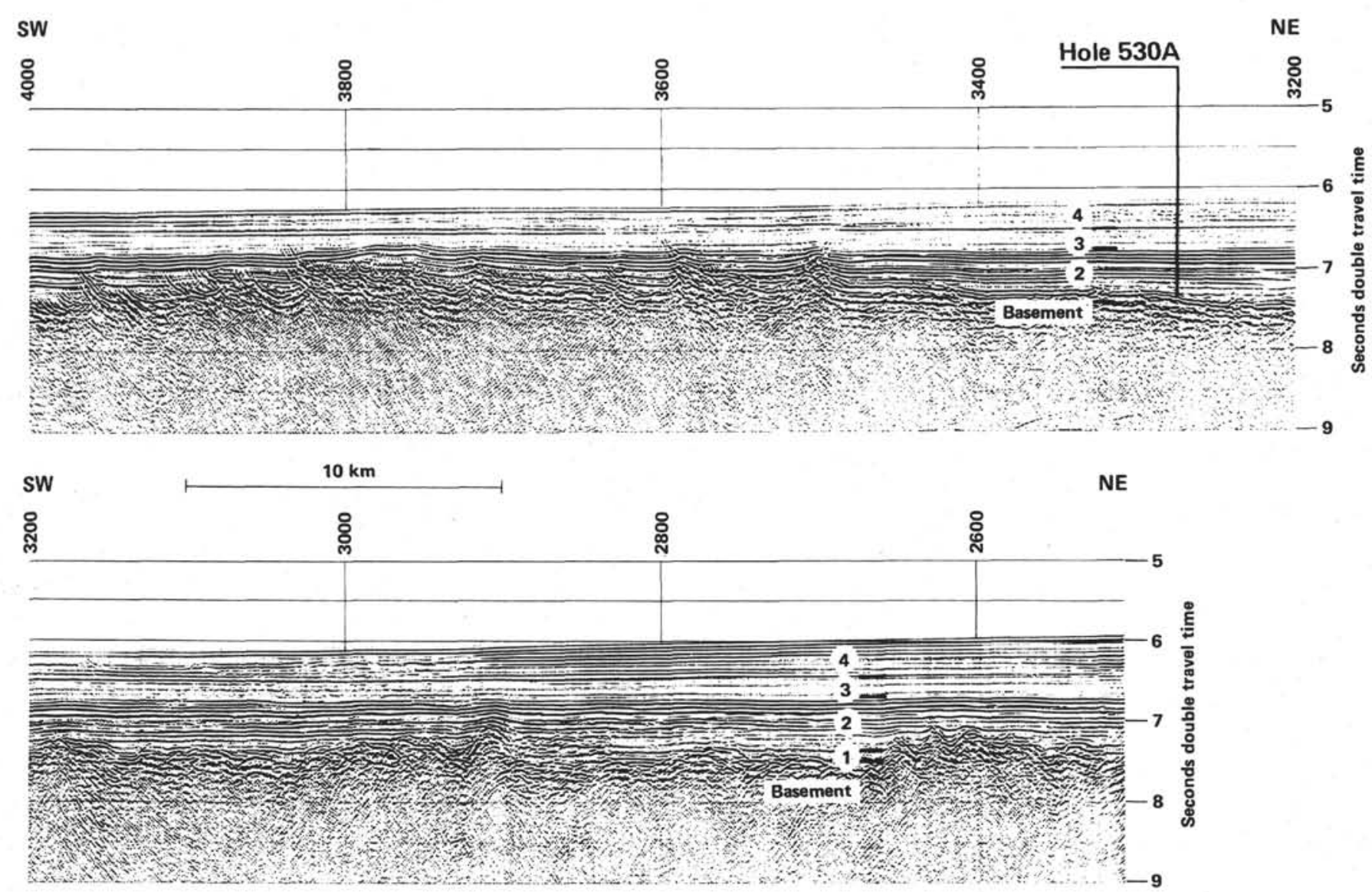

Figure 18. Migrated seismic section BGR-41 in the Angola Basin. The main acoustic units identified are: Unit 1, older than Cenomanian; Unit 2, Cenomanian to early Oligocene; Unit 3, early Oligocene to early late Miocene; Unit 4, early late Miocene to Holocene.

ume), and on oceanic basement of structural province 3 (Fig. 19). It also fills the depressions and especially the $\mathrm{N} 350^{\circ}$ trough which separates structural provinces 1 and 2 and which contains more than 2 sdtt of sediments (Fig. 20). By extrapolating sediment-accumulation and seafloor spreading rates from Site 530 to the continent/ ocean boundary near the continental margin of Angola, acoustic Unit 1 must be composed mainly of early Albian to Cenomanian sediments derived partly from the Angola continental margin, and partly from Walvis Ridge (Sibuet et al., and Stow, both this volume). Lower Cretaceous to Cenomanian sediments on Walvis Ridge are mainly detrital in the $\mathrm{N} 350^{\circ}$ basin. Upper Aptian to Albian limestones with terrigenous components occur on the top of the northern flank of Walvis Ridge which was close to sea level at that time.

The base of acoustic Unit 2 in the Angola Basin corresponds to a series of reflectors of moderate amplitude overlain by a series of parallel reflectors of high amplitude (Fig. 18). Acoustic Unit 2 on eastern Walvis Ridge is a well-layered sequence of later Cenomanian to early Oligocene age. It contains a Late Cretaceous discontinuity in the middle of the unit (Fig. 19) which marks the base of several channels that have cut into the underlying sequence. In the Angola Basin, fan deposits derived from Walvis Ridge occur throughout acoustic Unit 2 (the green- and white-fan facies of Stow, this volume). On eastern Walvis Ridge, sediments of acoustic Unit 2 are mostly marly limestone and chalk. A major pulse of terrigenous sediments at Site 362 (Bolli, Ryan, et al., 1978), ending in the late Campanian, may reflect a major peak in current activity which eroded sediments off Walvis Ridge and deposited them in the adjacent basins.

Acoustic Unit 3 is a transparent layer with faint subhorizontal reflectors. The base of acoustic Unit 3 corresponds to the major discontinuity AII of Emery et al. (1975) which can be correlated over the entire Angola Basin (Fig. 18). Acoustic Unit 3 corresponds to the red and green muds of lithologic Unit 3 at Site 530 (Fig. 2). The thickness of acoustic Unit 3 decreases from the Angola continental margin to the deep Angola Basin, and this suggests a primarily turbiditic source from the continental margin. On Walvis Ridge, the major source of sediment in acoustic Unit 3 is the shelf. The upper part of acoustic Unit 3 produces an irregular reflection pattern that is characteristic of a high energy environment where channels, levees, and sigmoidal bodies are common (Fig. 18). These sediments consist of marly ooze and chalk of early Oligocene to late Miocene age. They occur as cyclic interbeds of more terrestrial and more pelagic sediments.

Acoustic Unit 4 in the Angola Basin is characterized by discontinuous, subparallel reflectors with lateral variations both perpendicular and parallel to Walvis Ridge (Fig. 18). Acoustic Unit 4 consists partly of a series of slumps and flows derived from northern Walvis Ridge, 
but some of the sediments also were derived from the African continental margin to the northeast (Musgrove and Austin, this volume). At Site 530, acoustic Unit 4 is equivalent to lithologic Units 1 and 2 of late Miocene to Recent age (Fig. 2). On Walvis Ridge, acoustic Unit 4 changes from a sequence of well-stratified reflectors to a younger sequence with less stratified to wavy reflectors probably as a result of the effect of bottom currents on the top of the ridge (Fig. 19). At Sites 362 and 532, acoustic Unit 4 is composed of diatom and nannofossil ooze and marl with variable amounts of terrigenous clay and a high organic-carbon content which reflects the development of the Benguela upwelling system (Gardner et al., this volume).

\section{STRUCTURAL EVOLUTION OF WALVIS RIDGE AND ADJACENT BASINS}

Based on topography and basement morphology, the Walvis Ridge has been divided into four structural provinces. The Angola and Cape basins form two adjacent additional provinces (Fig. 19; Sibuet et al., this volume). Provinces 1 and 2 to the east and 3 and 4 to the west are separated by the 2,000-m isobath (Fig. 21); the eastern provinces have a basement of continental crust whereas the western provinces are underlain by oceanic crust. Seismic sections across the eastern provinces are characterized by parallel internal basement reflectors that generally dip seaward at angles of up to eight degrees, and are interrupted by faults every 5 to $10 \mathrm{~km}$ (Fig. 19). The vertical offset of these faults varies from hundreds of meters to several kilometers. The high density of multichannel seismic lines in this area allows us to draw the approximate net of fault lines (Fig. 21). Two main directions of faults are evident, one trending $\mathrm{N} 10^{\circ}$ and one trending $\mathrm{N} 60^{\circ}$. The $\mathrm{N} 60^{\circ}$ direction also is evident on maps of magnetic and gravity anomalies (Sibuet et al., this volume), and corresponds to the general orientation of the northern and southern flanks of Walvis Ridge as well as to the dominant direction of fracture zones (Fig. 20). The $\mathrm{N} 10^{\circ}$ faults occur within the elongated bands delineated by the $\mathrm{N} 60^{\circ}$ fault trends (Fig. 21). In the vicinity of the $500-\mathrm{m}$ isobath, the $\mathrm{N} 10^{\circ}$ fault delimits a depression oriented $\mathrm{N} 350^{\circ}$ which corresponds to the boundary between structural provinces 1 and 2 , and which is filled with more than $10 \mathrm{~km}$ of sediment. The $\mathrm{N} 10^{\circ}$ faults dip toward the axis of the $\mathrm{N} 350^{\circ}$ trending depression.

Sibuet et al. (this volume) suggest that structural provinces 1 and 2 are of continental origin based on the following indirect observations and conclusions:

1) The basement structure changes from a basement with an internal dipping-reflector sequence in provinces 1 and 2 to typical oceanic basement in province 3 .

2) The boundary between provinces 2 and 3 is distinct on the bathymetric, gravity, and magnetic maps.

3) Gravity modeling shows that a contrast in density or thickness of the crust occurs at the boundary between provinces 2 and 3 (Sibuet et al., this volume).

4) Based on the structural relationships of the tilted fault blocks, Sibuet et al. (this volume) computed a stretching value of 1.2 for the continental crust beneath eastern Walvis Ridge. This is comparable to the stretching value of 1.3 computed to be required for uniformly stretched continental crust initially at sea level to subside to its present depth on Walvis Ridge.

5) In terms of kinematic plate reconstruction, the spur which corresponds to provinces 1 and 2 fits into the gap just south of the São Paulo Plateau.

Since the beginning of the rifting phase in the Late Jurassic (Oxfordian to Kimmeridgian), the continental crust was progressively thinned, particularly in provinces 1 and 2 of Walvis Ridge. The maximum thinning occurred in the $\mathrm{N} 350^{\circ}$ trending depression that separates provinces 1 and 2 (Figs. 1, 21, and 22) and corresponds to the natural prolongation of the continental margins of Namibia and Angola. During the first period of this rifting phase (120 to $130 \mathrm{~m} . \mathrm{y}$.), a voluminous mass of volcanics was emplaced simultaneous with the emplacement of basalt in the Parana Basin of Brazil and the Kaokoveld region of Namibia (Sibuet et al., this volume). This period of volcanism probably also formed flows dipping in the direction of low points. This would explain the dipping reflectors that are characteristic of provinces 1 and 2 .

One of the objectives of Leg 75 was to determine the lithologies of these dipping reflectors which also are common in other areas such as the margins of Antarctica, east Greenland, Rockall Plateau, and the Voringe Plateau (Hinz, 1981). Because of safety considerations, the proposed site for drilling the dipping reflectors on Walvis Ridge was moved to Site 531 where they crop out. Unfortunately, the bottom was too firm to spud in. Nevertheless, the question of the nature of dipping reflectors was addressed on Rockall Plateau during Leg 81 (Deep Sea Drilling Project, 1982). Here, the dipping reflectors correspond to a thick sequence of basic igneous flows and tuffs with probable thin sedimentary interbeds. These flows were emplaced during the rifting episode in a shallow marine to subaerial environment. The divergent form of reflectors dipping seaward on the margin of Rockall Plateau is interpreted as a consequence of subsidence due both to the increase of crustal extension and to the load of the volcanics. Leg 81 results suggest that the dipping reflectors observed in provinces 1 and 2 of Walvis Ridge could be massive volcanic flows and tuffs with possible interbedded sedimentary layers that were deposited not only in a subaerial environment as suggested by Mutter et al. (1982) but also in a submarine environment (Deep Sea Drilling Project, 1982).

The maximum extension occurred in the deeper part of the $\mathrm{N} 350^{\circ}$ depression. A fault system developed in the brittle upper part of the crust, including the newly emplaced volcanic sequence. These faults dip toward the axis of the $\mathrm{N} 350^{\circ}$ depression and produced tilted fault blocks. The consequence of this type of tectonics is an increase in the initial dip of the basement reflectors in province 2 , whereas the dip angle of reflectors in province 1 is reduced because of the rotation of the tilted fault blocks (e.g., LePichon and Sibuet, 1981).

During the second phase of rifting, which ended before late Aptian (Sibuet et al., this volume), more tilted fault blocks were created in the upper brittle stratified 
W
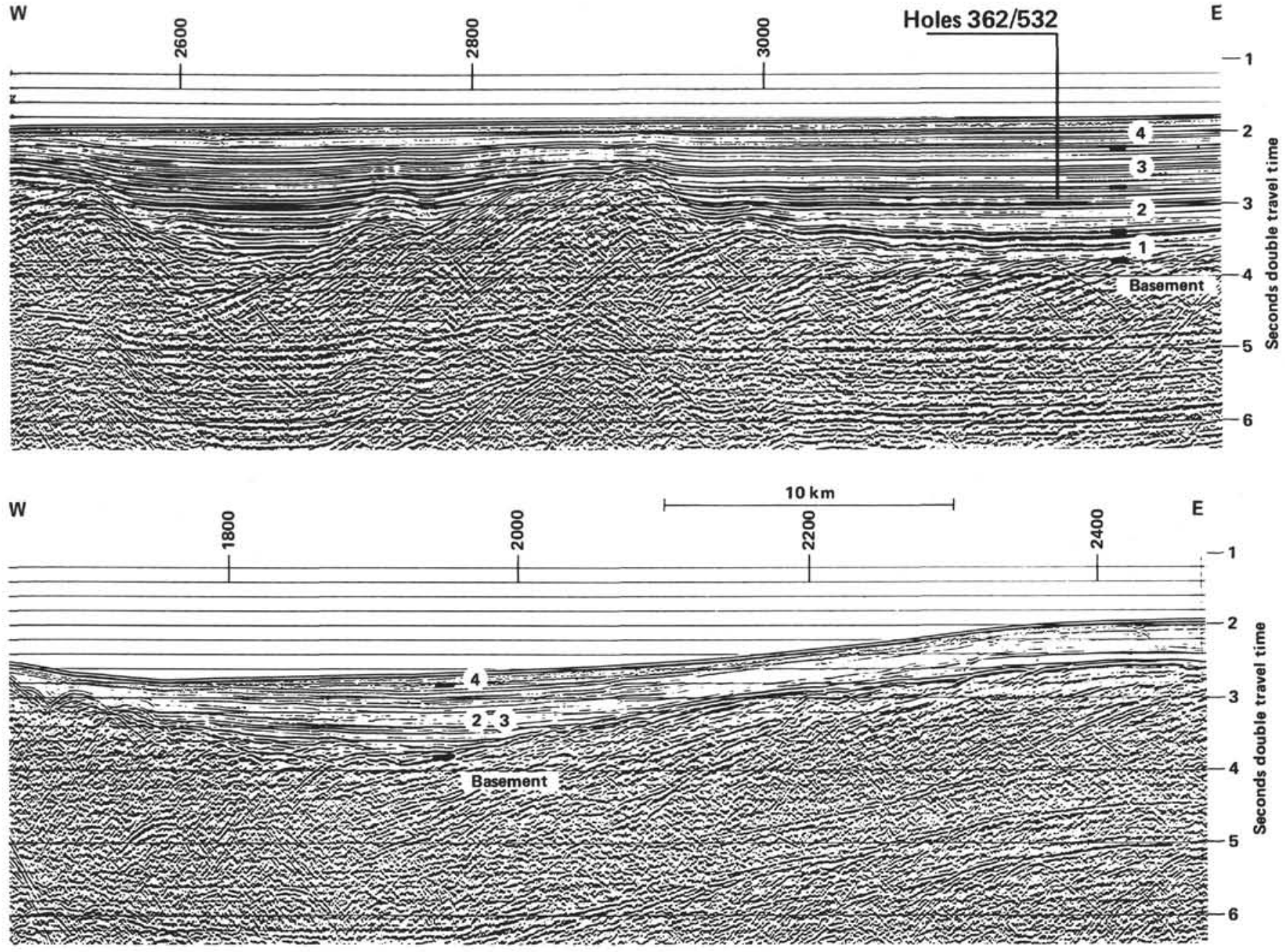

Figure 19. Processed seismic profile BGR-36. The approximate locations of DSDP Sites 362/532, 531, and 363, which are on or near the trackline, are indicated.

continental crust. These faults strike $\mathrm{N} 10^{\circ}$ and also dip toward the axis of the $\mathrm{N} 350^{\circ}$ trending depression. During this phase of rifting, some of the blocks may have been exposed to subaerial erosion, producing the observed flattening of the tops of many of the blocks. As expected the dip of the reflectors within the basement increases west of the $\mathrm{N} 350^{\circ}$ depression, and decreases east of the depression. Basalts may have been emplaced either close to sea level as shown by the recovered fragments of shallow-water calcareous algae at Site 363 (Bolli, Ryan, et al., 1978), or in a subaerial environment as suggested by the presence of probable erosional surfaces. The oceanic crust on Walvis Ridge was emplaced close to sea level, as in the Afar region. This requires less thinning of the continental crust than took place on the adjacent continental margins (LePichon and Sibuet, 1981). At least part of the oceanic crust of province 3 may have been emplaced before any oceanic crust formed in the adjacent basins. (Figs. 19, 20, and 22).

Rabinowitz (1976) and Cande and Rabinowitz (1978) have identified magnetic Anomaly M4 south of Walvis Ridge and Anomaly M3 north of the ridge in an area presently on the South American side (Figs. 21 and 22). This suggests that oceanic crust began to be emplaced both south and north of the ridge during the Barremian to early Aptian.

A ridge jump occurred during the late Aptian to early Albian in the southern part of the Angola Basin which translated the previously formed oceanic crust and its overlying salt deposits on the South American side (Cande and Rabinowitz, 1978; Sibuet et al., this volume) (Figs. 22, 23). Then, new oceanic crust was created, starting close to the base of the continental margin of Angola. The Cape Basin and Walvis Ridge continued to grow (Figs. 22, 23). A fracture zone consequently formed at the base of the northern flank of Walvis Ridge, so that oceanic crust in the Angola Basin is younger than on the adjacent Walvis Ridge (Fig. 20). This would explain both the fact that eastern Walvis Ridge and its adjacent basins are in local isostatic equilibrium and the slight depression that exists at the base of the northern flank of Walvis Ridge. This depression indicates that Walvis Ridge and the Angola Basin were not subsiding at the same rate because of their differences in age.

The boundary between structural provinces 3 and 4 probably corresponds to a major change in the mode of formation of the ridge from the construction of a large oceanic pile between two close fracture zones, to an ac- 

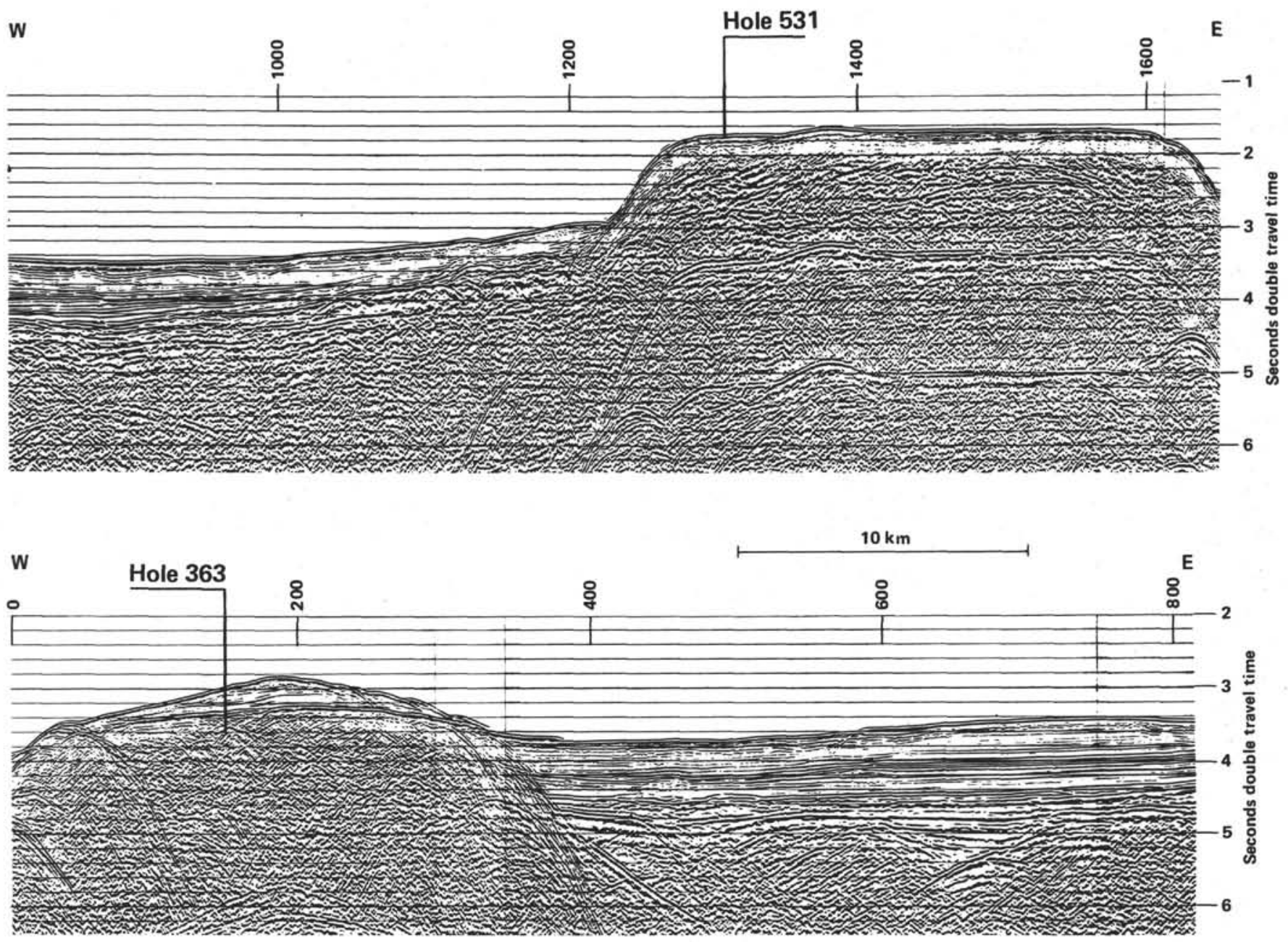

Figure 19. (Continued).

cretionary spreading center located between two fracture zones separated by $500 \mathrm{~km}$. Several ridge jumps occurred on both sides of Walvis Ridge during the Late Cretaceous and early Tertiary to produce this $500-\mathrm{km}$ long segment of mid-oceanic ridge, which includes Valdevia Bank.

The fit of continents proposed by Bullard et al. (1965) has been widely accepted for the South Atlantic. Sibuet and Mascle (1978), using more recent bathymetric data, did not find any significant differences. As a first approximation, the continental reconstruction of Bullard et al. (1965) has therefore been used for the initial reassembly of Walvis Ridge, Rio Grande Rise, and the adjacent continents (Fig. 23). In this reconstruction, the spur corresponding to structural provinces 1 and 2 of eastern Walvis Ridge is located just south of the São Paulo Plateau. The bathymetric trend of the southern part of the São Paulo Plateau is parallel with and corresponds to the northern flank of Walvis Ridge.

The strong similarity in nature and age of the Parana Basin and Torres syncline of Brazil, and the Kaokoveld region of Namibia (Fig. 23; Neill, 1976) suggest that structural provinces 1 and 2 also were the location of volcanic flows that correspond to the series of dipping reflectors within the acoustic basement. Basaltic and surrounding alkalic rocks of Late Jurassic to Early Cretaceous age (Herz, 1977) of the Parana Basin and Torres syncline could have been emplaced on a short-lived arm of an R-R-R triple junction located on the South American side (Neill, 1976; Herz, 1977; Asmus and Guazelli, 1981). The volcanic activity on the African side in provinces 1 and 2 of Walvis Ridge and in the Kaokoveld region probably corresponds to the intraplate volcanism in the prolongation of the Parana Basin. This two-plate system existed in South America between 120 and 148 m.y. ago, with maximum activity between 120 and 130 m.y. ago. The evolution of eastern Walvis Ridge therefore appears to be closely related to the occurrence of a triple junction system and associated intraplate tectonics in the prolongation of the South American arm of the ridge system.

\section{ACKNOWLEDGMENTS}

We are particularly grateful to the shipboard scientific staff, the crew of the D/V Glomar Challenger, and the shore-based DSDP staff who helped during the many stages of manuscript production for helping to make Leg 75 such a technical and scientific success. We also thank the many authors of papers in this volume and of earlier contributions who helped to document the geologic evolution, sedimentation and paleoenvironments of the Angola Basin and Walvis Ridge, and without whose contributions this synthesis would not be possible. 


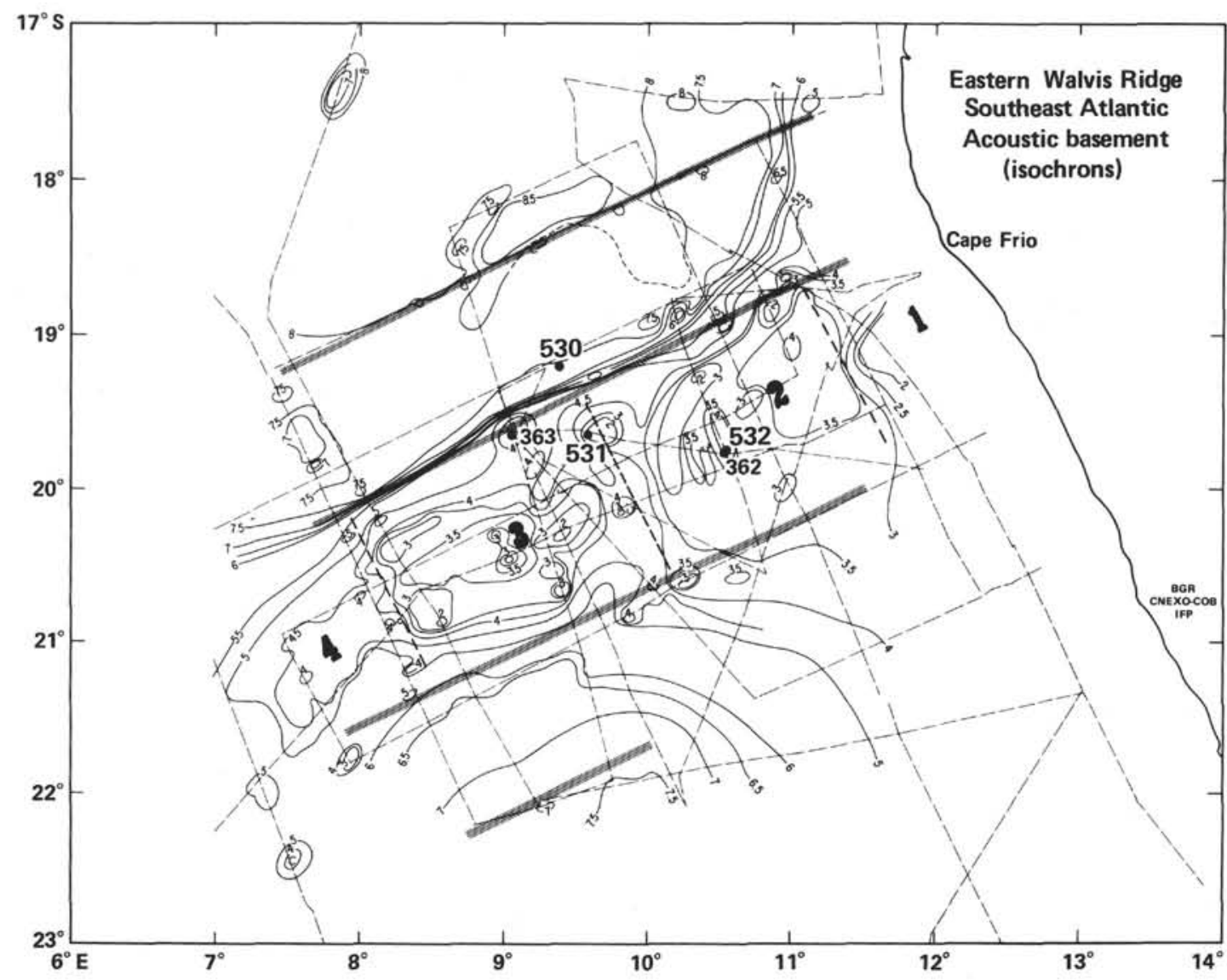

Figure 20. Basement map of eastern Walvis Ridge and adjacent parts of the Cape and Angola basins. Contours are in seconds of double travel time (sdtt). Contour interval is 0.5 sdtt. Seismic lines used for control are indicated by dashed lines. The four main structural provinces on Walvis Ridge are indicated by large numbers, and the boundaries between structural provinces are indicated by heavy dashed lines. Hachures correspond to inferred fracture zones.

Frank Azaro, Helen Michel, Waltet and Luis Alvarez kindly provided the iridum data from the Cretaceous/Tertiary Boundary although these data were not available in time to submit in a contributed report. Contribution No. 833 of the Centre Océanologique de Britagne.

\section{REFERENCES}

Adeleye, D. R., 1975. Nigerian Late Cretaceous stratigraphy and paleogeography. Am. Assoc. Pet. Geol. Bull.59:2302-2313.

Alvarez, L. W., Alvarez, W., Asaro, F., and Michel, H. V., 1980. Extraterrestrial cause for the Cretaceous-Tertiary extinction. Science, 208:1095-1108.

Alvarez, W., Alvarez, L. W., Asaro, F., and Michel, H. V., 1982. Current status of the impact theory for the terminal Cretaceous extinction. In Silver, L. T., and Schultz, P. H. (Eds.), Geological Implications of Inputs of Large Asteroids and Comets on the Earth. Geol. Soc. Am. Spec. Pap., 190:305-315.

Arthur, M. A., and Natland, J. H., 1979. Carbonaceous sediments in the North and South Atlantic: The role of salinity in stable stratification of Early Cretaceous basins. In Talwani, M., Hay, W. W., and Ryan, W. B. F. (Eds.), Deep Drilling Results in the Atlantic Ocean: Continental Margins and Paleoenvironment: Washington (Am. Geophys. Union), Maurice Ewing Series, 2:375-401.

Arthur, M. A., and Schlanger, S. O., 1979. Cretaceous "oceanic anoxic events" as causal factors in development of reef-reservoired giant oilfields. Am. Assoc. Pet. Geol. Bull., 63:870-885.

Asmus, H. E., and Guazelli, W., 1981. Descriao sumaria das estruturas da margem continental brasileira e das areas oceanicas et continentais, adjacentes-hypotheses sobre o tectonismo causador, e implicacoes para os prognosticos do potential de recursos minerais. In Asmus, H. E. (Ed.), Estruturas e Tectonismo da
Margem Continental Brasileira, e Suas Implicacoes Nos Processos Sedimentares e na Availacao do Potencial de Recursos Minerais: Rio de Janeiro, Brazil. (Projeto Remac, Petrobras), 9:187-269.

Barker, P., Dalziel, I., et al., 1977. Init. Repts. DSDP, 36: Washington (U.S. Govt. Printing Office).

Barnaby, A. M., 1974. The structure of the eastern Walvis Ridge and the adjacent continental margins [M. Sc. Dissect.]. University of Cape Town, South Africa.

Berger, W. H., 1973. Cenozoic sedimentation in the eastern tropical Pacific. Geol. Soc. Am. Bull., 84:1941-1954.

1981. Paleoceanography: The deep-sea record. In Emiliani, C. (Ed.), The Oceanic Lithosphere, The Sea (Vol. 7): New York (Wiley-Interscience), 1437-1519.

Berger, W. H., and Roth, P. H., 1975. Oceanic micropaleontology: Progress and prospect. Rev. Geophys. Space Phys., 13:561-585.

Berger, W. H., and Winterer, E. L., 1974. Plate stratigraphy and the fluctuating carbonate line. In Hsü, K. J., and Jenkyns, H. C. (Eds.), Pelagic Sediments on Land and Under the Sea. Int. Assoc. Sediment. Spec. Publ., 1:11-48.

Bolli, H. M., Ryan, W. B. F., et al., 1978. Init. Repts. DSDP, 40: Washington (U. S. Govt. Printing Office).

Brass, G. W., Saltzman, E., Sloan, J. L. II, Southam, J. R., Hay, W. W., Holser, W. T., and Peterson, W. H., 1982. Ocean circulation, plate tectonics and climate. Climate in Earth History: Washington (National Academy Press), pp. 83-89.

Brass, G. W., Southam, J. R., and Peterson, W. H., 1982. Warm saline bottom water in the ancient ocean. Nature, 296:620-623.

Boersma, A., and Shackleton, N. J., 1977a. Oxygen and carbon isotopic record through the Oligocene, Site 366, equatorial Atlantic. In Supko, P. R., Perch-Nielsen, K., et al., Init. Repts. DSDP, 39: Washington (U.S. Govt. Printing Office), 957-962. 
1977b. Tertiary oxygen and carbon isotope stratigraphy, Site 357 (mid-latitude South Atlantic). In Perch-Nielsen, K., Supko, P. R., et al., Init. Repts. DSDP, 39: Washington (U.S. Govt. Printing Office), 911-924.

Bullard, E. C., Everett, J. E., and Smith, A. G., 1965. The fit of the continents around the Atlantic. In Blackett, P. M. S., Bullard, E. C., and Runcorn, S. K. (Eds.), A Symposium on Continental Drift. Philos. Trans. R. Soc., A258:41-51.

Cande, S., and Rabinowitz, P. D., 1978. Mesozoic sea floor spreading bordering conjugate continental margins of Angola and Brazil. Offshore Tech. Conf. Proc., Rep. OTC 3268, Houston, Texas, 1869-1876.

Connary, S. D., and Ewing, M., 1974. Penetration of Antarctic Bottom Water from the Cape Basin into the Angola Basin. J. Geophys. Res., 79:463-469.

Dean, W. E., Claypool, G. E., and Thiede, J., 1981. Origin of organic carbon-rich mid-Cretaceous limestones, mid-Pacific mountains and southern Hess Rise. In Thiede, J., Vallier, T. L., et al., Init. Repts. DSDP, 62: Washington (U.S. Govt. Printing Office, 877-890.

Deep Sea Drilling Project, 1982. Leg 81 drills west margin, Rockall Plateau. Geotimes, 21-23.

Diester-Haass, L., 1978. Sediments as indicators of upwelling. In Boje, R., and Tomczak, M. (Eds.), Upwelling Ecosystems: Berlin (Springer-Verlag), pp. 261-281.

Diester-Haass, L., and Schrader, H.-J., 1979. Neogene coastal upwelling history off northwest and southwest Africa. Mar. Geol., 29: 39-53.

Dietz, R. S., and Holden, J. C., 1970. Reconstruction of Pangea: Break-up and dispersion of continents, Permian to present. $J$. Geophys. Res., 75:4939-4956.

Douglas, R. G., and Savin, S. M., 1975. Oxygen and carbon isotope analyses of Tertiary and Cretaceous microfossils from Shatsky Rise and other sites in the North Pacific Ocean. In Larson, R. L., Moberly, R., et al., Init. Repts. DSDP, 32: Washington (U.S. Govt. Printing Office), 509-521.

Emery, K. O., Phillips, J., Bowin, C., and Mascle, J., 1975. Continental margin off western Africa: Angola to Sierra Leone. Am. Assoc. Pet. Geol. Bull., 59:2209-2265.

Emery, K. O., Uchupi, E., Bowin, C., Phillips, J., and Simpson, E. S. W., 1975. Continental margin off western Africa: Cape St. Francis (South Africa) to Walvis Ridge (South-West Africa). Am. Assoc. Pet. Geol. Bull., 59:3-59.

Fischer, A. G., and Arthur, M. A., 1977. Secular variations in the pelagic realm. In Cook, H. E., and Enos, P. (Eds.), Deep Water Carbonate Environments. Soc. Econ. Paleontol. Mineral. Spec. Publ., 25:19-50.

Frakes, L. A., and Kemp, E. M., 1972. Influence of continental positions on early Tertiary climates. Nature, 243:19-21.

Francheteau, J., and LePichon, X., 1972. Marginal fracture zone as structural framework of continental margins in the South Atlantic Ocean. Am. Assoc. Pet. Geol. Bull., 56:991-1007.

Goslin, J., Mascle, J., Sibuet J.-C., and Hoskins, H., 1974. Geophysical study of the easternmost Walvis Ridge, South Atlantic: Morphology and shallow structure. Geol. Soc. Am. Bull., 85:619-632.

Goslin, J., and Sibuet, J.-C., 1975. Geophysical study of the easternmost Walvis Ridge, South Atlantic: Deep structure. Geol. Soc. Am. Bull., 86:1713-1724.

Habicht, J. K. A., 1979. Paleoclimate, paleomagnetism, and continental drift. Am. Assoc. Pet. Geol. Stud. Geol., 9:1-31.

Hay, W. W., and Southam, J. R., 1977. Modulation of marine sedimentation by the continental shelves. In Anderson, N. R., and Malahoff, A. (Eds.), The Role of Fossile Fuel $\mathrm{CO}_{2}$ in the Oceans: New York (Plenum Press), pp. 569-605.

Hay, W. W., Sibuet, J.-C., et al., 1982. Sedimentation and accumulation of organic carbon in the Angola Basin and on Walvis Ridge: Preliminary results of Deep Sea Drilling Project Leg 75. Geol. Soc. Am. Bull., 93:1038-1050.

Hayes, D. E., Frakes, L. A., et al., 1975. Init. Repts. DSDP, 28: Washington (U.S. Govt. Printing Office)

Heath, G. R., 1969. Carbonate sedimentation in the abyssal equatorial Pacific during the past 50 million years. Geol. Soc. Am. Bull., 80:689-694.

Hekinian, R., 1972. Volcanics from the Walvis Ridge in the southeast Atlantic Ocean. Earth Planet. Sci. Lett., 35:225-233.
Herz, N., 1977. Timing of spreading in the South Atlantic: Information from Brazilian alkalic rocks. Geol. Soc. Am. Bull., 88: 101-112.

Hinz, K., 1981. A hypothesis on terrestrial catastrophies: Wedges of very thick oceanward dipping layers beneath passive continental margins-their origin and paleoenvironmental significance. Geol. J., 22:3-28.

Hsü, K. J., LaBrecque, J. L., et al., in press. Init. Repts. DSDP, 73: Washington (U.S. Govt. Printing Office).

Hsü, K. J., McKenzie, J. A., and He, Q. X., 1982. Terminal Cretaceous environmental and evolutionary changes. In Silver, L. T., and Schultz, P. H. (Eds.), Geological Implications of Inputs of Large Asteroids and Comets on the Earth. Geol. Soc. Am. Spec. Pap., 190:317-328.

Hsü, K. J., Ryan, W. B. F., and Cita, M. B., 1973. The origin of the Mediterranean evaporites. In Ryan, W.B.F., Hsü, et al., Init. Repts. DSDP, 13 (Pt. 2): Washington (U.S. Govt. Printing Office), 1203-1231.

Jenkyns, H. C., 1980. Cretaceous anoxic events: From oceans to continents. J. Geol. Soc. London, 137:171-188.

Kennett, J. P., Houtz, R. E., et al., 1974. Cenozoic paleo-oceanography in the southwest Pacific Ocean, Antarctic glaciation, and the development of the circum-Antarctic current. In Kennett, J. P., Houtz, R. E., et al., Init. Repts. DSDP, 29: Washington (U.S. Govt. Printing Office), 1155-1169.

Kingsman, D. J. J., 1976. Evaporites: Relative humidity control of primary mineral facies. J. Sed. Petrol., 46:273-279.

LePichon, X., and Sibuet, J.-C., 1981. Passive margins: A model of formation. J. Geophys. Res., 86:3708-3720.

Lowrie, W., Alvarez, W., Napoleone, G., Perch-Nielsen, K., Premoli Silva, I., and Toumarkine, M., 1982. Paleogene magnetic stratigraphy in Umbrian pelagic carbonate rocks. Geol. Soc. Am. Bull., 93:414-432.

Ludwig, W. M., Krasheninnikow, V. A., et al., 1983. Init. Repts. DSDP, 71: Washington (U.S. Govt. Printing Office).

McConnell, R. B., 1969. Fundamental fault zones in the Guiana and West African shields in relation to presumed axes of Atlantic spreading. Geol. Soc. Am. Bull., 80:1775-1782.

McCoy, F. W., and Zimmerman, H. B., 1977. A history of sediment lithofacies in the South Atlantic Ocean. In Perch-Nielsen, K. Supko, P. R., et al., Init. Repts. of DSDP, 39: Washington (U.S. Govt. Printing Office), 1047-1079.

Machens, E., 1973. The geologic history of the marginal basins along the north shore of the Gulf of Guinea. In Nairn, A. E. M., and Stehli, F. G. (Eds.), The Ocean Basins and Margins, The South Atlantic (Vol. 1): New York (Plenum Press), 351-390.

Melguen, M., 1978. Facies evolution, carbonate dissolution cycles in sediments from the eastern South Atlantic (DSDP Leg 40) since the Early Cretaceous. In Bolli, H. M., Ryan, W. B. F., et al., Init. Repts. DSDP, 40: Washington (U.S. Govt. Printing Office), 981-1003.

Moore, T. C., Jr., Rabinowitz, P. D., et al., in press. Init. Repts. DSDP, 74: Washington (U.S. Govt. Printing Office).

Morgan, W. J., 1971. Convection plumes in the lower mantle. Nature, 230:42-48.

1972. Deep mantle convection plumes and plate motions. Am. Assoc. Petl. Geol. Bull., 56:203-213.

Musgrove, L. A., and Austin, J. A., Jr., 1983. Intrabasement structure in the southern Angola Basin. Geology, 11:169-173.

Mutter, J. C., Talwani, M., and Stoffa, P. L., 1982. Origin of seaward dipping reflectors in oceanic crust off the Norwegian margin by subaerial sea-floor spreading. Geology, 10:353-357.

Natland, J., 1978. Composition, provenance, and diagenesis of Cretaceous clastic sediments drilled on the Atlantic continental rise off southern Africa, DSDP Site 361. In Bolli, H. M., Ryan, W. B. F., et al., Init. Repts. DSDP, 40: Washington (U.S. Govt. Printing Office), $1025-1062$.

Neill, W. M., 1976. Mesozoic epeirogeny at the South Atlantic margin and the Tristan hot spot. Geology, 4:495-498.

Neuman, G., and Pierson, W. J., Jr., 1966. Principles of Physical Oceanography: Englewood Cliffs, N. J. (Prentice-Hall).

Perlman, I., and Asaro, F., 1969. Pottery analysis by neutron activation. Archaeometry, 11:21-52.

1971. In Brill, R. H. (Ed.), Science and Archaeology: Cambridge, Massachusetts (MIT Press), p. 182. 
Peterson, W. H., Brass, G. W., and Southam, J. R., 1981. The formation of warm saline bottom water in ancient oceans. Ocean Modeling, 38:1-7.

Rabinowitz, P. D., 1976. A geophysical study of the continental margins of southern Africa. Geol. Soc. Am. Bull., 87:1643-1653.

Reyment, R. A., and Tait, E. A., 1972. Biostratigraphical dating of the early history of the South Atlantic Ocean. Philos. Trans. R. Soc. London, 264B:55-95.

Saltzman, E., and Barron, E. J., 1982. Deep circulation in the Late Cretaceous: Oxygen isotope paleotemperatures from Inoceramus remains in DSDP cores. Palaeogeogr., Palaeoclimatol., Palaeocecol., 40:167-181.

Savin, S. M., 1977. History of the earth's surface temperature during the past 100 million years. Ann. Rev. Earth Planet. Sci., 5: 319-355.

1982. Stable isotopes in climatic reconstructions. Climate and Earth History: Washington (National Academy Press) pp. 164-171.

Savin, S. M., Douglas, R. G., and Stehli, F. G., 1975. Tertiary marine paleotemperatures. Geol. Soc. Am. Bull., 86:1499-1510.

Savin, S. M., and Yeh, H.-W., 1981. Stable isotopes in ocean sediments. In Emiliani, C. (Ed.), The Oceanic Lithosphere, The Sea (Vol. 7): New York (John Wiley and Sons), 1521-1554.

Schilling, J. G., Kingsley, R., Humphris, S. E., and Thompson, G. 1981. Tristan da Cunha hot spot. EOS, Trans. Am. Geophys. Union., 62:424.

Schlanger, S. O., and Jenkyns, H. C., 1976. Cretaceous oceanic anoxic events-causes and consequences. Geol. Mijnbouw, 55: 179-184.

Schuette, G., and Schrader, H., 1981. Diatom taphocoenoses in coastal upwelling area off southwest Africa. Mar. Micropaleontol., 6:131-155.

Shackleton, N. J., and Kennett, J. P., 1974a, Late Cenozoic oxygen and carbon isotope changes at DSDP Site 284: Implications for glacial history of the northern hemisphere and Antarctic. In Kennett, J. P., Houtz, R. E., et al., Init. Repts. DSDP, 29: Washington (U.S. Govt. Printing Office), 801-807.

Shackleton, N. J., and Opdyke, N. D., 1977. Oxygen isotope and paleomagnetic evidence for early northern hemisphere glaciation. Nature, 270:216-219.

Sibuet, J.-C., and Mascle, J., 1978. Plate kinematic implications of Atlantic equatorial fracture zone trends. J. Geophys, Res., 83: 3401-3421.

Siesser, W. G., 1980. Late Miocene origin of the Benguela upwelling system off northern Namibia. Science, 208:283-285.

Southam, J. R., and Hay, W. W., 1982. Global sedimentary mass balance and sea level changes. In Emiliani, C. (Ed.), The Oceanic Lithosphere, The Sea (Vol. 7): New York (John Wiley and Sons), 1617-1684.

Supko, P. R., Perch-Nielson, K., et al., 1977. Init. Repts. DSDP, 39: Washington (U.S. Govt. Printing Office).
Thiede, J., Dean, W. E., and Claypool, G. E., 1982. Oxygen-deficient depositional paleoenvironments in the mid-Cretaceous tropical and subtropical Pacific Ocean. In Schlanger, S. O., and Cita, M. B. (Eds.), Nature and origin of Cretaceous Carbon-Rich Facies. London (Academic Press), pp. 79-100.

Thiede, J., and van Andel, Tj. H., 1977. The deposition of anaerobic sediments in the late Mesozoic Atlantic Ocean. Earth Planet. Sci. Lett., 33:301-309.

Thompson, S. L., and Barron, E. J., 1981. Comparison of Cretaceous and present earth albedos: Implications for the causes of paleoclimates. J. Geol., 89:143-167.

Tissot, B., Demaison, G., Masson, P., Delteil, J. R., and Combaz, A., 1980. Paleoenvironment and petroleum potential of middle Cretaceous black shales in Atlantic basins. Am. Assoc. Petl. Geol. Bull., 64:2051-2063.

Vail, P. R., Mitchem, R. M., and Thompson, S. III., 1977. Seismic stratigraphy and global changes of sea level, Pt. 4: Global cycles of relative changes of sea level. In Payton, C. E. (Ed.), Seismic Stratigraphy-Applications to Hydrocarbon Exploration. Am. Assoc. Petl. Geol. Mem., 26:83-97.

Vallier, T. L., Dean, W. E., Rea, D. K., and Thiede, J., 1983. Geology and paleoenvironments of Hess Rise, central North Pacific Ocean: Implications for the evolution of oceanic plateaus. Geol. Soc. Am. Bull., 94.

Vallier, T. L., Rea, D. K., Dean, W. E., Thiede, J., and Adelseck, C. G., 1981. The geology of Hess Rise, central North Pacific Ocean. In Thiede, J., Vallier, T. L., et al., Init. Repts. DSDP, 62: Washington (U.S. Govt. Printing Office), 1031-1072.

van Andel, Tj. H., and Moore, T., 1974. Cenozoic calcium carbonate distribution and calcite compensation depth in the central equatorial Pacific. Geology, 2:87-92.

van Andel, Tj. H., Thiede, J., Sclater, J. G., and Hay, W. W., 1977. Depositional history of the South Atlantic Ocean during the last 125 million years. J. Geol., 85:651-698.

van der Linden, W. J. M., 1980. Walvis Ridge, a piece of Africa? Geology, 8:417-421.

von der Dick, H. Rullkötter, J., and Welte, D. H., 1983. Content, type, and thermal evolution of organic matter in sediments from the eastern Falkland Plateau, Deep Sea Drilling Project, Leg 71. In Ludwig, W. J., Krasheninnikov, V. A., et al., Init. Repts., DSDP, 71 (Pt. 2): Washington (U.S. Govt. Printing Office), 1015-1032.

Wilde, P., and Berry, W. B. N., 1982. Progressive ventilation of the oceans-potential for return of anoxic conditions in the post-Paleozoic. In Schlanger, S. O., and Cita, M. B. (Eds.), Nature and Origin of Cretaceous Carbon-rich Facies: London (Academic Press), pp. 209-224.

Worsley, T. R., and Davies, T. A., 1979. Sea level fluctuations and deep sea sedimentation rates. Science, 203:455-456.

Date of Initial Receipt: June 24, 1983 


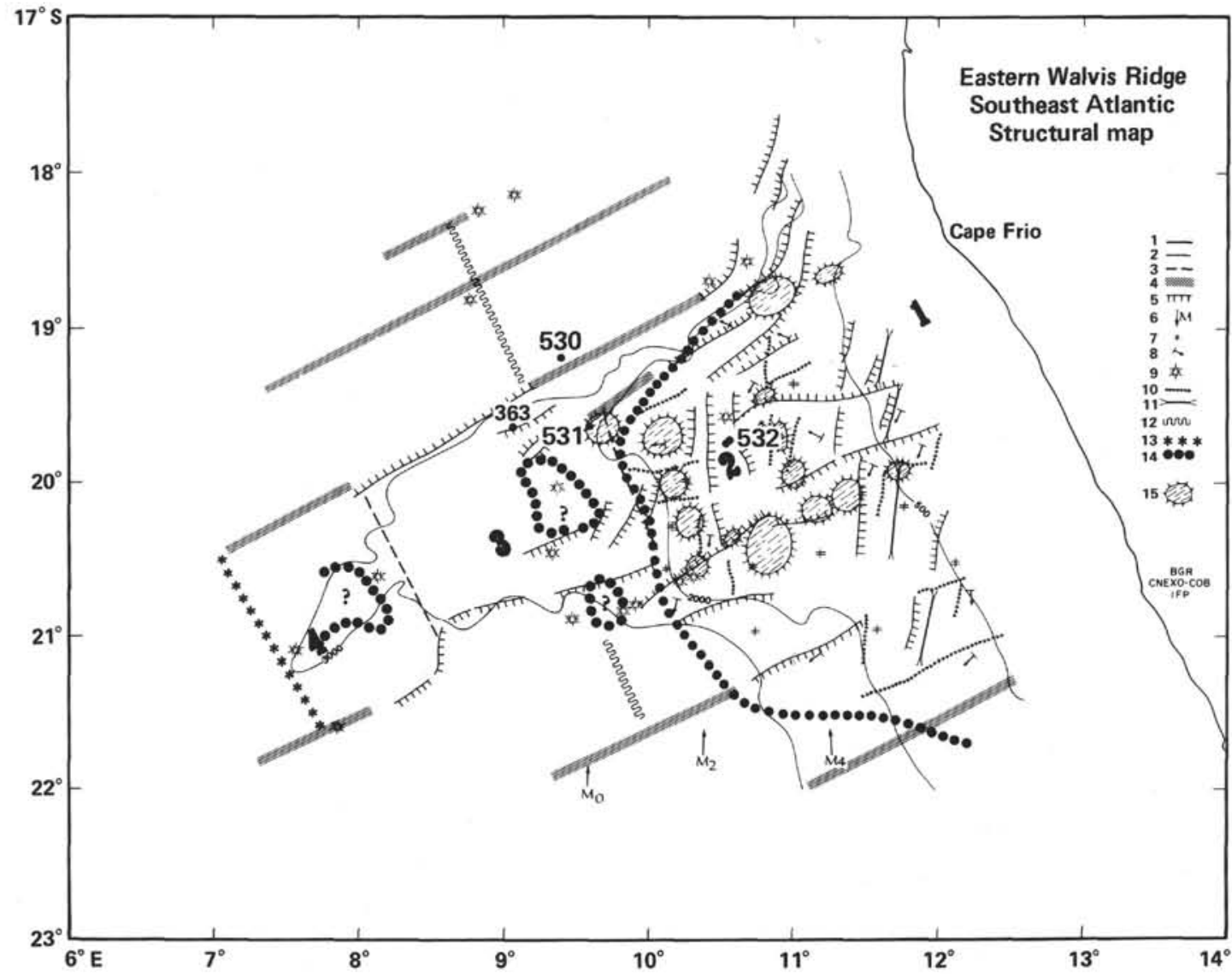

1) Main isobaths. 2) Trackline control. 3) Boundaries between the four main structural provinces of the ridge. 4) Fracture zones. 5) Faults 6) Identified magnetic anomalies. 7,8) Dip of subacoustic basement reflectors. 9) Major volcanic features in the basement topography. 10) Direction of structural lines deduced from deep basement reflectors. 11) Axis of the depression located at the boundary between structural provinces 1 and 2. 12) Western boundary of pre-Cenomanian deposits. 13) Western boundary of the pre-Campanian deposits. 14) Limit of occurrence of deep basement reflectors. 15) Eroded surfaces or sites of nondeposition.

Figure 21. Structural map of eastern Walvis Ridge. 


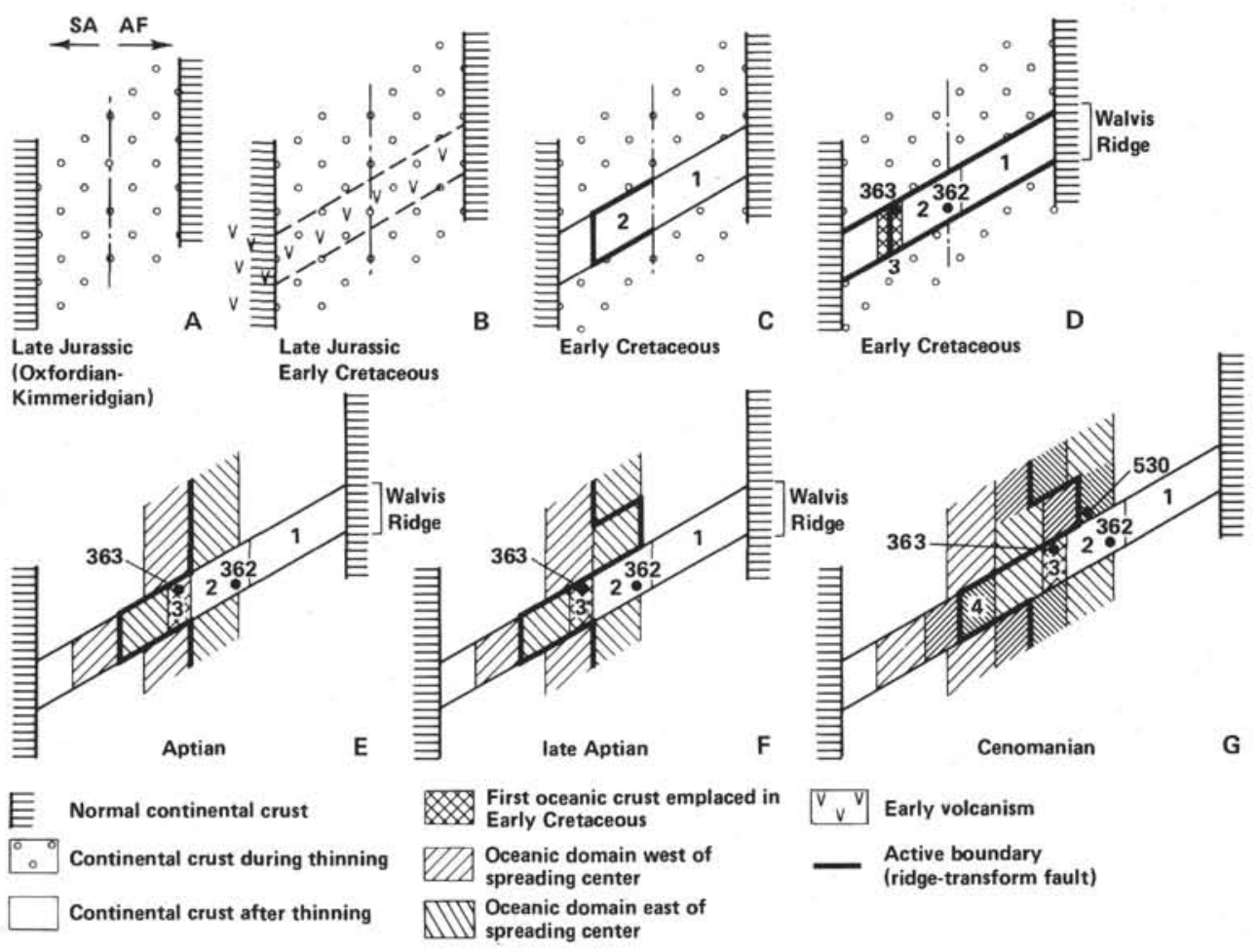

Figure 22. Schematic diagrams showing the evolution of eastern Walvis Ridge for seven time periods.

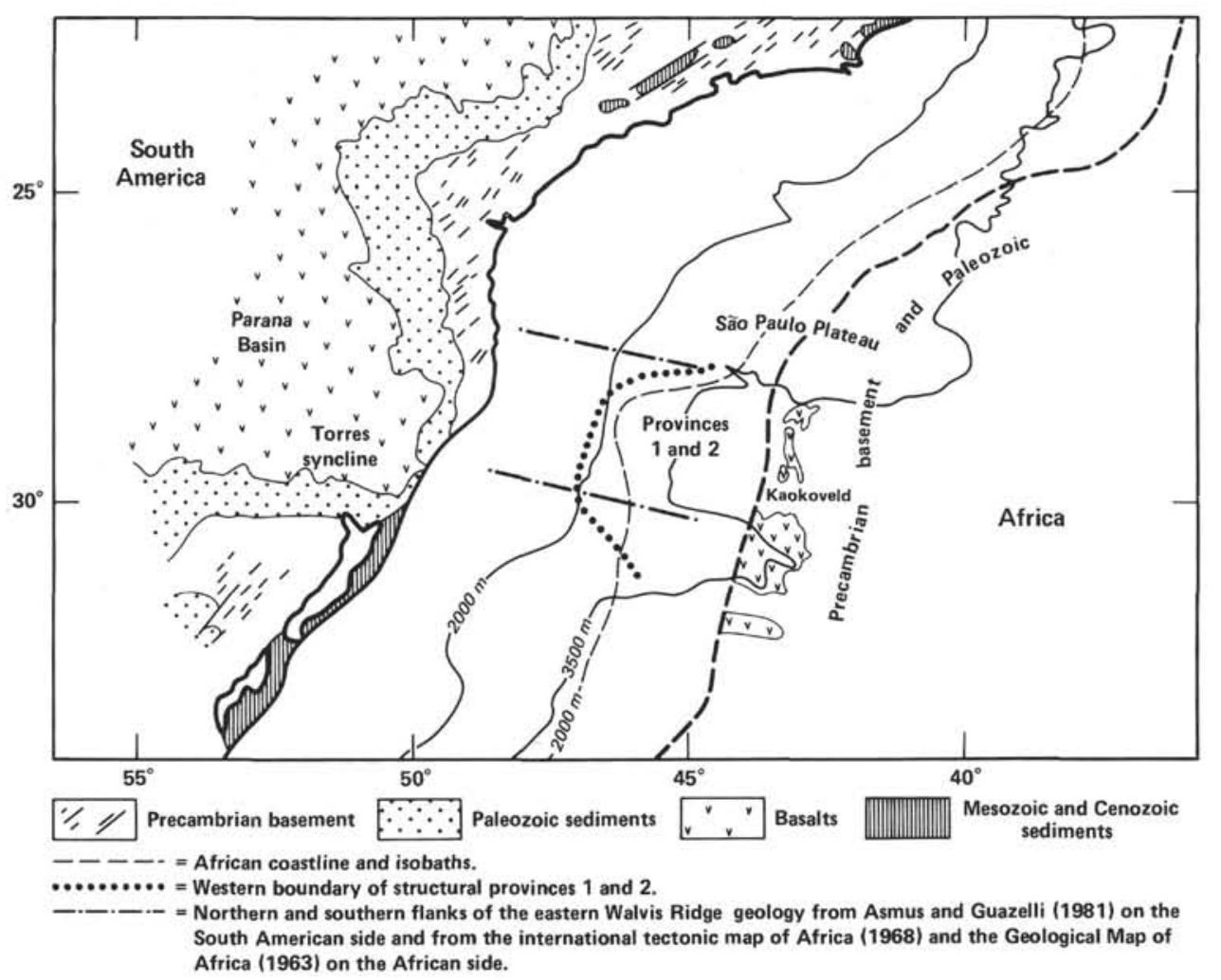

Figure 23. Initial recontruction of southeastern South America and southwestern Africa in the areas of the Parana Basin and Torres syncline of Brazil, structural provinces 1 and 2 of Walvis Ridge, and the Kaokoveld region of South Africa using the fit of Bullard et al. (1965). Dashed line, African coastline and isobaths; dotted line, western boundary of structural provinces 1 and 2 on Walvis Ridge; dash-dot line, northern and southern flanks of the eastern Walvis Ridge. Geology is from Asmus and Guazelli (1981) on the South American side, and from the International Tectonic Map of Africa (1968) and the Geological Map of Africa (1963) on the African side. 